\title{
Phylogenetic classification of bony fishes
}

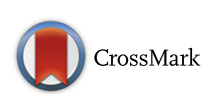

\author{
Ricardo Betancur-R ${ }^{1,2^{*}}$, Edward O. Wiley ${ }^{3,4}$, Gloria Arratia ${ }^{3}$, Arturo Acero ${ }^{5}$, Nicolas Bailly ${ }^{6}$, Masaki Miya ${ }^{7}$, \\ Guillaume Lecointre ${ }^{8}$ and Guillermo Ortî, ${ }^{2,9}$
}

\begin{abstract}
Background: Fish classifications, as those of most other taxonomic groups, are being transformed drastically as new molecular phylogenies provide support for natural groups that were unanticipated by previous studies. A brief review of the main criteria used by ichthyologists to define their classifications during the last 50 years, however, reveals slow progress towards using an explicit phylogenetic framework. Instead, the trend has been to rely, in varying degrees, on deep-rooted anatomical concepts and authority, often mixing taxa with explicit phylogenetic support with arbitrary groupings. Two leading sources in ichthyology frequently used for fish classifications (JS Nelson's volumes of Fishes of the World and W. Eschmeyer's Catalog of Fishes) fail to adopt a global phylogenetic framework despite much recent progress made towards the resolution of the fish Tree of Life. The first explicit phylogenetic classification of bony fishes was published in 2013, based on a comprehensive molecular phylogeny (www.deepfin.org). We here update the first version of that classification by incorporating the most recent phylogenetic results.
\end{abstract}

Results: The updated classification presented here is based on phylogenies inferred using molecular and genomic data for nearly 2000 fishes. A total of 72 orders (and 79 suborders) are recognized in this version, compared with 66 orders in version 1 . The phylogeny resolves placement of 410 families, or $~ 80 \%$ of the total of 514 families of bony fishes currently recognized. The ordinal status of 30 percomorph families included in this study, however, remains uncertain (incertae sedis in the series Carangaria, Ovalentaria, or Eupercaria). Comments to support taxonomic decisions and comparisons with conflicting taxonomic groups proposed by others are presented. We also highlight cases were morphological support exist for the groups being classified.

Conclusions: This version of the phylogenetic classification of bony fishes is substantially improved, providing resolution for more taxa than previous versions, based on more densely sampled phylogenetic trees. The classification presented in this study represents, unlike any other, the most up-to-date hypothesis of the Tree of Life of fishes.

"Characterem non constituero Genus, sed Genus Characterem" - C Linnaeus [1].

"Such expressions as that famous one of Linnaeus [1] ... that the characters do not make the genus, but that the genus gives the characters, seem to imply that something more is included in our classifications, than mere resemblance. I believe that something more is included; and that propinquity of descent - the only known cause of the similarity of organic beings - is the bond, hidden as it is by various degrees of modification, which is partially revealed to us by our classifications."

- CR Darwin [2].

\footnotetext{
* Correspondence: betanri@fishphylogeny.org

${ }^{1}$ Department of Biology, University of Puerto Rico, Río Piedras, P.O. Box

23360, San Juan, PR 00931, USA

2Department of Vertebrate Zoology, National Museum of Natural History,

Smithsonian Institution, Washington, DC, USA

Full list of author information is available at the end of the article
}

"These guys knew what they were talking about! It is kind of amazing that Linnaeus [1] made the first statement, even though he did not yet fully understand evolutionary relationships (propinquity of descent in Darwin's words [2]) as the underlying basis of those higher taxa. It is a shame that this basic and important principle of life is still not understood by the majority of people... even many practicing biologists! Characters do not "define" taxa; taxa are "defined" by their common ancestry (just like other historical groups, like human families). Because taxa share a common ancestry, they often share many characters, which we may use to recognize them. But if one of the species in a taxon lacks one of those characters (but is still clearly part of the group), it is still part of the taxon. It is one of the simplest and most fundamental ideas in biology, and yet so many people (even biologists) seem not to understand this simple concept." 
- D Hillis [3].

"Since taxonomy tends, ideally, not toward just any type of convenient classification of living forms... but toward a phyletic classification, and since the comparison of the structure of homologous informational macromolecules allows the establishment of phylogenetic relationships, studies of chemical paleogenetics have a bearing on taxonomy."

- E Zuckerkandl and L Pauling [4].

"The conflict between these two approaches, the former which could be called phenetic (or typological), and the latter which could be called phyletic (or evolutionary), is not a new conflict, but to the uninitiated it gives the ichthyological literature something of a chaotic aspect. The situation is not improved by authors who are neither strictly phenetic nor phyletic in approach... In the writer's opinion, we ultimately will have a purely phyletic classification, and this will be achieved in relation to our progress in unraveling the phyletic interrelationships of the Recent fishes... There is little doubt that the methods of comparative biology are adequate for revealing ancestral conditions, even without knowledge of ancestordescendant relationships among organisms of the past. Such knowledge will never be available to us, for only in the genetics laboratory, and for organisms of the present, is such knowledge possible."

- G Nelson [5].

\section{Background}

Classification is an integral part of all sciences. The basis for classifications differs between disciplines but the basic principles are the same- in all cases we seek to understand something fundamental about the things classified. For astronomers, it is understanding the mass-luminosity relationships that lead to unraveling stellar evolution. For chemists, it is understanding how the atomic structure of elements leads to knowing how reactions occur. For systematists, it is understanding the relationships of organisms in the Tree of Life. The meaning of "relationship" in systematics has changed over time, but today it unquestionably means the genealogical affinities produced by the history of evolutionary descent. Notions of grades or levels of organization (shades of Lamarck or the Scala Naturae) are displaced by understanding that if a classification is organized strictly according to our best estimate of the Tree of Life, the organization of organisms becomes more predictive and straightforward, just as knowing the mass-luminosity relationships of a star will predict its future evolution or knowing that since the orbitals of a helium atom are full it is likely to not react with an atom of oxygen. Beyond doubt, the principles of phylogenetic systematics are now accepted as a rule; the most useful classification of organisms is that advocated, though never achieved, by Darwin.
The "modern era" classification of fishes is considered by many to begin in 1966 with the publication of a provisional classification of teleosts based on "phyletic thinking" [6]. Prior to this work, the most general classification in use had been proposed by LS Berg [7], from which the endings of modern orders ("-formes") were retained. PH Greenwood, DE Rosen, SH Weitzman and GS Myers [6] turned the attention of systematic ichthyologists of the day toward classifications that reflected the perceived evolutionary histories of fishes. Many modern clades were not only recognized, they were coupled with explicit characterizations. Many of these characterizations turned out to be synapomorphies supporting many of the clades still recognized today. The work stands as the last pre-cladistic general classification of fishes, revolutionary in that there was explicit phyletic thinking, and yet arranged more along the lines of Simpson's classification of mammals with its reliance on grades of organization and ancestral groups than on the concepts of strict monophyly and sister-group relationships we recognize today. But, importantly to subsequent developments, PH Greenwood, DE Rosen, SH Weitzman and GS Myers [6] rejected two things, phenetics (group taxa based solely on apparent similarity) and the central role of fossils to classification of recent fishes. Today, fossils are important, of course, not only because they allow estimating divergence times via molecular clock calibrations [8-14], but also because it is becoming increasingly clear that integrating paleontological and neontological data improves our understanding of the Tree of Life of fishes [15-25] and their macroevolutionary history [26-30].

The first explicitly phylogenetic classification of fishes was published by G Nelson [5] together with a clear discussion of the principles of phylogenetic systematics. Although at the time "phyletic interrelationships" among the included species and higher taxa were quite controversial, G Nelson [5] presented simple cladograms based on earlier views of vertebrate evolution (e.g., [31]) to justify his classification. His proposal discarded the use of grades and ancestral groups and rejected the idea that "gaps," rates of change, or any other criterion previously accepted by evolutionary systematists [32], could be used to justify elevating the rank of a particular group higher than that of its closest relative. Thus, birds are classified with crocodiles in Archosauria and the entire clade of tetrapods is found within Sarcopterygii. The revolution had begun, spurred on by publication of the multiauthored Interrelationship of Fishes [33]. It is not our place to detail this revolution, it happened slowly as investigators learned how to infer phylogenies and translate their findings into explicit phylogenetic classifications [34]. Many of these changes to fish classifications in general and phylogenetic classification in particular are summarized in $\mathrm{DE}$ 
Rosen [35], GV Lauder and KF Liem [36], and M Stiassny, L Parenti and G Johnson [37]. They are reflected to a greater or lesser degree in various editions of JS Nelson's Fishes of the World [38-42]. Of particular interest is the observation that much of the work on teleosts began at the base and worked upward rather than from the crown and downward (but see [43]). One of the initial concerns was establishing the monophyly of teleosts (see [17, 44-46]), and another was sorting out the relationships among earlybranching teleost groups (i.e., osteoglossomorphs, elopomorphs, and clupeocephalans $[17,25,45,47,48])$, working upward through the euteleosts [49] and establishing the sequential relationships of lineages leading to the percomorphs [50-53]. By 1989, G Nelson famously summarized these efforts with the observation that although much progress to resolve the early branching patterns of the Tree of Life of fishes had been achieved, the major challenge was to resolve the problematic relationships among percomorphs: "the bush at the top" problem [54].

GD Johnson and C Patterson [51] presented an influential study with new evidence to address the percomorph problem using a then customary "exemplar" approach to survey variation and propose putative synapomorphies, rather than the standard matrix-based analyses with dense taxon sampling to optimize character states required nowadays. It is important to note that many studies addressing high-order relationships and delineation of major lineages of percomorphs based on morphological data were not based on explicit phylogenetic analyses, and hence relied mostly on authoritative summaries and synthesis of patterns of variation $[55,56]$. The empirical evidence underpinning these advances was eventually compiled by EO Wiley and GD Johnson [57] through a detailed survey of the literature, producing a list of putative morphological synapomorphies for groups down to the subordinal level. They presented a classification for Actinopterygii justifying groups by evidence presented by others to support their monophyly. In doing so, EO Wiley and GD Johnson [57] "flattened" the higher teleost classification into a series of orders principally because there was no morphological evidence supporting hypotheses of relationships among those orders (the exception was the "Smegmamorpharia", a group no longer considered monophyletic). That it is "flat" for percomorphs with a polytomy of orders is a naked acknowledgement that they lacked evidence for the relationships among these groups. The Perciformes - the largest vertebrate order, long regarded as a polyphyletic taxonomic wastebasket (e.g., [41, 42, 50, 51, 57-59]) - was circumscribed to include families not placed in other orders and tagged as a group without synapomorphies. EO Wiley and GD Johnson [57] could not create structure where no anatomical evidence for structure existed.
Starting around the mid-1970s (and before the era of internet), the most influential source for fish classification has been JS Nelson's Fishes of the World [38-42], receiving more than 9300 citations (Google Scholar, as of March 2017). Another monumental effort that synthesizes knowledge on systematic ichthyology is Eschmeyer's Catalog of Fishes [60], an authoritative reference for taxonomic fish names, featuring a searchable on-line database (http://www.calacademy.org/scientists/ projects/catalog-of-fishes), with a print version published in 1998 [61] and a recent list of family-level names [62]. This database also indicates carefully curated valid names and their synonyms under the classification of JS Nelson's Fishes of the World with modifications. It has been constantly updated since the 1980s and gradually became another obligatory reference facilitated by the pervasive influence of the internet. Only JS Nelson's Fishes of the World uses explicit criteria to justify the taxonomic arrangements, while Eschmeyer's Catalog of Fishes is mostly intended for nomenclatural purposes. The phylogenetic criteria used by JS Nelson to update his classifications, however, have been based mostly on his personal views of the value of morphological evidence to define phylogenetic hypotheses [63], resulting in often poorly justified combinations of previous hypotheses in order to achieve a perceived "community consensus" view of phylogeny. This tendency, to "use restraint in revising classifications and incorporate a judicious mix of the old and the new" (see foreword by L. Parent in [42]), continues in the current edition [42], featuring an eclectic mix of new molecular hypotheses and traditionally accepted yet unsupported clades (e.g., Perciformes) without explicit criteria. As noted by G Nelson [5] almost half a century ago (quoted above), ambiguous approaches in systematics are not likely to improve clarity in the ichthyological literature.

The contribution of molecular characters to establish high-order phylogenetic relationships among fishes started in the $1990 \mathrm{~s}$ - although the importance of molecular characters was anticipated much earlier; see above quote by E Zuckerkandl and L Pauling [4] - with analyses of $28 \mathrm{~S}$ rRNA sequences obtained via reverse transcription [64]. A significant result of these early molecular studies, summarized by G Lecointre and G Nelson [65], suggested affinities between clupeomorphs and ostariophysans (see also G Arratia [66] and GD Johnson and C Patterson [49] for morphological support). Analyses of complete mitochondrial genome sequences, starting in 1999, contributed extensively to reveal additional unanticipated affinities among lineages of fishes [67], resulting in more than 83 papers (e.g., [68-72]) reporting phylogenetic analyses of more than 1340 mitogenomic sequences between 1999 and 2014 (see also [73]). Prompted by the advent of genomics, larger sets of nuclear gene 
markers became available at the beginning of this century [74], opening a new window for inference of multilocus phylogenetic trees (e.g., [75-87]). Steady progress towards acquisition of larger molecular datasets via PCR and Sanger-sequencing technology in subsequent years rapidly produced multigene phylogenies (up to 20 gene fragments) that significantly improved our knowledge of fish relationships. The most recent large-scale analyses included hundreds to thousands of species across the Tree of Life of fishes [8, 10, 11, 88-90], many of which contributed to the resolution of the percomorph bush [54] into nine well-supported supra-ordinal clades (see below) $[8$, $27,91,92]$. These large-scale studies also provided, for the first time, a monophyletic definition of Perciformes. Most recently, massively parallel ("next generation") sequencing technologies, in combination with efficient methods to capture thousands of markers in a single reaction (e.g., target enrichment $[93,94])$, has ushered in a promising future to tackle difficult phylogenetic questions by analyzing hundreds or thousands of gene fragments [95]. However, genome-scale comparisons among fishes based on hundreds of loci have been limited so far to studies including a few dozen [96-100] or a couple hundred fish taxa [101-103], largely supporting previous studies based on smaller number of genes (but see [101]). Compilation of genome-scale databases to enable large-scale phylogenomic studies of fishes is actively underway [104-108].

Here, we present a revised phylogenetic classification for bony fishes based on multi-locus trees inferred for nearly 2000 species. The classification is an update of the three previous versions (including two online updates posted on www.deepfin.org), originally published by R Betancur-R., RE Broughton, EO Wiley, K Carpenter, JA Lopez, C Li, NI Holcroft, D Arcila, M Sanciangco, J Cureton, et al. [8] and built on the Linnean scheme proposed by EO Wiley and GD Johnson [57]. Our phylogenetic classification has been adopted by several public databases and documentation resources, including NCBI (www.ncbi.nlm.nih.gov/Taxonomy), the Paleobiology Database (www.paleobiodb.org), FishBase (www.fishbase.org), Catalogue of Life (www.catalogueoflife.org [109]), and OneZoom (www.onezoom.org). The new version presented here incorporates phylogenetic results from recent studies and fixes involuntary errors and omissions. We also highlight and comment all cases where taxonomic decisions made by JS Nelson, T Grande and MVH Wilson [42] are in conflict with current phylogenetic hypotheses supporting this classification, as well as the differences with WN Eschmeyer [60] and R Van Der Laan, WN Eschmeyer and R Fricke [62].

\section{Construction and content}

The phylogenetic framework for this version of the classification (version 4) is based on a recent update of the fish Tree of Life [27] with the addition of four clades obtained by large-scale phylogenetic studies: cypriniforms [102], non-cypriniform otophysans (i.e., Characiformes, Siluriformes and Gymnotiformes; [101]), percomorphs [92], and syngnatharians [103]. Input subtrees were time-scaled using the R [110] package Ape ("chronos" function [111]) and grafted to the backbone tree using custom R code (see Additional files 1 and 2) based on secondary age calibrations and functions implemented in the R package phytools [112]. The secondary calibrations were obtained from a Bayesian analysis of a subset of 201 taxa with 61 fossil age constraints (primary calibrations). Further details on phylogenetic inference, fossil calibrations, and divergence time estimates are given in the original study [8]. This study does not intend to provide a new time scale for fish evolution; instead, it provides a synthesis of our current knowledge of fish divergence times into the extended phylogenetic tree assembled herein. Shallow-level relationships and ages for many specific groups should be taken cautiously.

The complete time tree includes 1990 species of extant bony fishes and two chondrichthyian outgroups (Figs. 1 and 2). This revision preserves names and taxonomic composition of groups presented in previous versions as much as possible; however, adjustments have been made to recognize well-supported clades, many of which have been obtained by other recent studies. Criteria for recognizing and naming clades, as in previous versions, include measures of support (bootstrap) and consistent resolution obtained by independent studies (indicated in each case). For stability purposes, we adopt some names proposed in the most recent edition of Fishes of the World [42] when they do not contradict our phylogeny (Fig. 2). Examples include classification of suborders in Osmeriformes, Zeiformes and Beryciformes, validation of Trachichthyiformes and recognition of Acanthopterygii. A complete list of 29 changes made in accordance with JS Nelson, T Grande and MVH Wilson [42] is presented in Additional file 3B. Many of the groups classified by JS Nelson, T Grande and MVH Wilson [42], however, are incongruent with our phylogeny and are thus not recognized. Examples of non-monophyletic taxa, as circumscribed by JS Nelson, T Grande and MVH Wilson [42], but not recognized here include Osmeromorpha, Zoroteleostei and Moroniformes. Others are recognized here, but have considerably different circumscriptions (e.g., Scombriformes, Perciformes). Tables 1 and 2 provide an exhaustive comparison of ordinal and supraordinal taxa and families that differ between this classification and JS Nelson, T Grande and MVH Wilson [42], respectively. Table 2 also lists differences with families recognized by $\mathrm{R}$ Van Der Laan, WN Eschmeyer and R Fricke [62].

A total of 72 orders and 79 suborders of bony fishes are classified in this version (compared to only 66 orders 


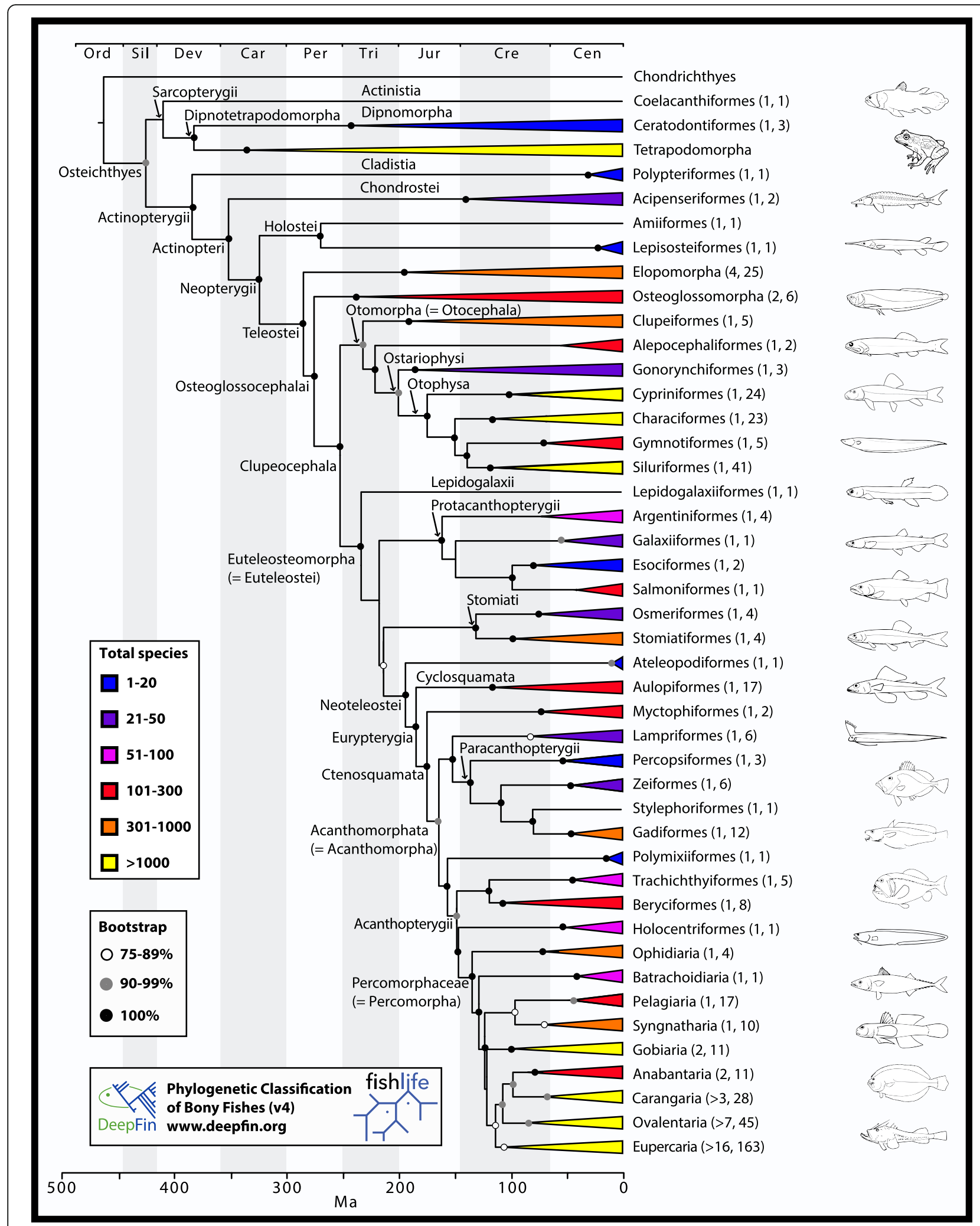

Fig. 1 Time-calibrated Fish Tree of Life with collapsed clades that highlight the relationships of major groups (ordinal or supraordinal taxa). The backbone tree is from R Betancur-R., G Orti and AR Pyron [27], with four taxonomically-dense clades grafted (see details under "Construction and content"). The complete tree is based on 1990 species of bony fishes (see Fig. 2). Numbers in parenthesis indicate number of orders and families included in each major clade, respectively. Please see Additional file 5 for high resolution image 


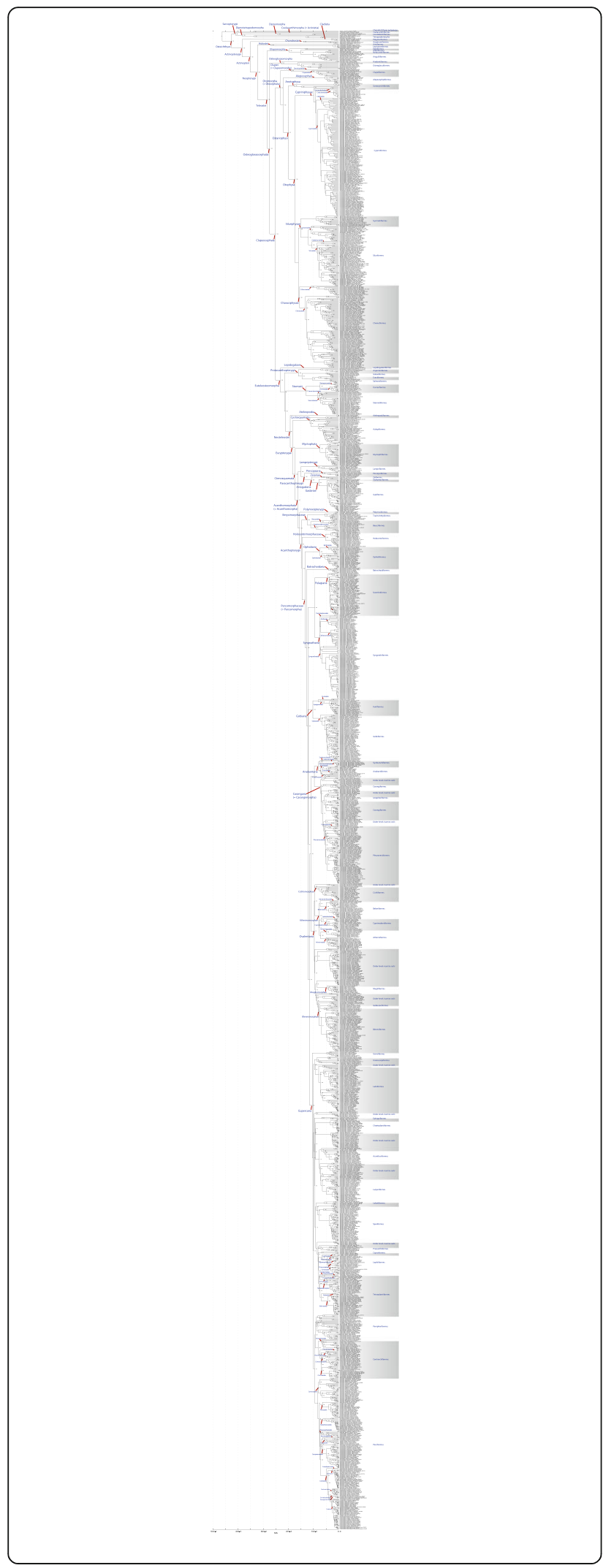

Fig. 2 Complete time-calibrated phylogeny including 1990 species of bony fishes. Taxon labels at the tips indicate family, species name, and specimen code (Family_Genus_species_Code). The backbone tree is from R Betancur-R., G Orti and AR Pyron [27], with four taxonomicallydense clades grafted: cypriniforms [102], non-cypriniform otophysans (i.e., Characiformes, Siluriformes and Gymnotiformes; [101]), percomorphs [92], and syngnatharians [103]. Taxonomic annotations for suborders, orders and higher taxonomic groups are shown in blue. Some nonmonophyletic suborders are not annotated (e.g., within Aulopiformes). Nodal numbers indicate bootstrap support values (not available for Cypriniformes or Syngnatharia, but see [102] and [103], respectively). To see details either zoom in (article PDF) or download the figure online. Please see Additional file 6 for high resolution image

in version 1). For each order/suborder we list all families examined as well as the unexamined families whose inclusion is expected on the basis of traditional classifications or other phylogenetic evidence. Order-level or supraordinal taxa are herein endorsed based on wellsupported clades $(>90 \%$ bootstrap values) or based on clades featuring lower support in the current tree, which are otherwise consistently obtained by other studies. In some cases, order-level taxa that are not monophyletic in our analysis are also validated, provided the incongruence is not substantially rejected by our results (i.e., incongruent clades that are poorly supported in our phylogeny). The classification is presented in phylogenetic order up to the subordinal rank (following the branching order in our tree), but families within orders and suborders are listed alphabetically (including hyperlinks to FishBase; Additional file 3A only).

Family names are largely based on R Van Der Laan, WN Eschmeyer and R Fricke [62] and WN Eschmeyer and JD Fong [113], but with several exceptions (Table 2). These studies should be consulted for authorship of family names. A total of 514 families of bony fishes are now recognized (excluding tetrapods), of which 410 $(\sim 80 \%)$ are included in our large-scale phylogenetic tree (Fig. 2). The list of 104 unexamined families can be obtained from Additional file 4 (spreadsheet) that also contains the complete classification, and is intended as a resource to stimulate future phylogenetic studies. To minimize the number of non-monophyletic taxa, we have changed the membership of some traditionally recognized families whose validity is strongly challenged by phylogenetic evidence. For instance, we no longer recognize families such as Carapidae, Scaridae, Caesionidae, and Microdesmidae (lumped with Ophidiidae, Labridae, Lutjanidae, and Gobiidae, respectively). Five lineages currently recognized as separate family-level entities ("Cyclopsettidae", "Percalatidae", "Percophidae", "Rivulidae" and "Pantanodontidae") await formal nomenclatural description in compliance with the International Code of Zoological Nomenclature (ICZN). The ordinal status of 30 percomorph families (vs. 50 in version 1) 
Table 1 Remarkable differences for ordinal or supraordinal taxa between JS Nelson, T Grande and MVH Wilson's (NGW [42]) classification and the update proposed herein. The circumscription of other orders may also differ due to variations in family validation (see Table 2) or due to inclusion of fossil taxa in NGW. Differences in taxonomic ranks and endings are considered minor and thus are not listed herein. NEL: [41]

\begin{tabular}{|c|c|c|}
\hline Taxon (order-level or above) & Differences with NGW & Justification/Remarks \\
\hline $\begin{array}{l}\text { Teleostomi, Ginglymodi, } \\
\text { Halecomorphi and } \\
\text { Teleosteomorpha/Teleocephala }\end{array}$ & Not classified herein & $\begin{array}{l}\text { Redundant with Osteichthyes, Amiiformes, Lepisosteiformes, and } \\
\text { Teleostei, respectively, when only extant taxa are considered. }\end{array}$ \\
\hline Dipnotetrapodomorpha & Not classified by NGW & $\begin{array}{l}\text { Only shown in one of NGW's cladograms but not formally } \\
\text { classified therein. }\end{array}$ \\
\hline Actinopteri & Not classified by NGW & Non-polypteriform actinopterygiians; a robust clade. \\
\hline Elopocephalai & Not classified by NGW & Not a major difference; it is redundant with Elopomorpha. \\
\hline Anguilliformes, Gadiformes & Classified into suborders in NGW but not herein & Phylogenetic incongruence with most subordinal classifications. \\
\hline Cypriniformes & Classified into suborders herein but not in NGW & Following [102]. \\
\hline Cetopsoidei & Not classified herein & The subordinal classification for Siluriformes follows [198]. \\
\hline Protacanthopterygii & $\begin{array}{l}\text { Includes four orders herein and only two in } \\
\text { NGW }\end{array}$ & $\begin{array}{l}\text { Differences are in part due to phylogenetic uncertainty. We } \\
\text { classify this taxon as sedis mutabilis. }\end{array}$ \\
\hline Zoroteleostei & Classified by NGW only & $\begin{array}{l}\text { Circumscription of this taxon is in conflict with } \\
\text { Protacanthopterygii. See comments in text. }\end{array}$ \\
\hline Osmeromorpha & Classified by NGW only & $\begin{array}{l}\text { Circumscription of this taxon is incongruent with all recent } \\
\text { higher-level phylogenetic analyses of fishes. See comments in } \\
\text { text. }\end{array}$ \\
\hline Stomiati & Not classified by NGW & $\begin{array}{l}\text { The circumscription of Stomiati herein is in conflict with NGW's } \\
\text { Osmeromorpha. See comments above and in text. }\end{array}$ \\
\hline Stomiiformes/Stomiatiformes & Spelling & Stomiatiformes sensu [43]; Stomiiformes sensu [207]. \\
\hline Stomiatoidei/Phosichthyoidei & Phosichthyoidei sensu NGW; Stomiatoidei herein & Based on Stomiidae. \\
\hline Paracanthopterygii & Includes Polymixiiformes in NGW but not here & $\begin{array}{l}\text { Polymixia has a rogue placement among early acanthomorphs. } \\
\text { Our classification is robust to phylogenetic uncertainty. }\end{array}$ \\
\hline Zeiogadaria & Not classified by NGW & $\begin{array}{l}\text { Denotes a robust clade including Zeiformes + (Stylephoriformes } \\
\text { + Gadiformes); this taxon has been recognized before (i.e., } \\
\text { Zeiogadiformes sensu [80]). }\end{array}$ \\
\hline Berycimorphaceae/Berycida & $\begin{array}{l}\text { Berycida sensu NGW is similar to } \\
\text { Berycimorphaceae as classified herein, but the } \\
\text { former includes Holocentriformes }\end{array}$ & $\begin{array}{l}\text { Holocentridae is sometimes recovered as the sister taxon of } \\
\text { percomophs, which may render Berycida sensu NGW non- } \\
\text { monophyletic. }\end{array}$ \\
\hline Anoplogastroidei & Not classified herein & Not monophyletic. \\
\hline Trachichthyoidei & Not classified herein & Not monophyletic. \\
\hline Holocentrimorphaceae & Not classified by NGW & Included in Berycida sensu NGW. See comments above. \\
\hline Pelagiaria & Not classified by NGW & $\begin{array}{l}\text { A robust clade (series) including } 17 \text { families in the order } \\
\text { Scombriformes, as classified herein. }\end{array}$ \\
\hline Scombriformes & $\begin{array}{l}\text { Includes } 17 \text { families herein and only nine in } \\
\text { NGW }\end{array}$ & $\begin{array}{l}\text { Scombriformes sensu NGW is paraphyletic considering all } \\
\text { higher-level molecular phylogenies of percomorphs. }\end{array}$ \\
\hline Scombroidei and Stromateoidei & Not classified herein & $\begin{array}{l}\text { Interfamilial resolution in Scombriformes is tenuous; classification } \\
\text { of scombriform families into suborders requires further work. }\end{array}$ \\
\hline Icosteiformes & Not classified herein & $\begin{array}{l}\text { Icosteidae, the sole family in this order, is part of Pelagiaria } \\
\text { (Scombriformes) herein. }\end{array}$ \\
\hline Scombrolabraciformes & Not classified herein & $\begin{array}{l}\text { Scombrolabracidae, the sole family in this order, is part of } \\
\text { Pelagiaria (Scombriformes) herein. }\end{array}$ \\
\hline Trachiniformes & $\begin{array}{l}\text { Not classified herein (similar to } \\
\text { Uranoscopiformes) }\end{array}$ & $\begin{array}{l}\text { Trachiniformes sensu NGW is polyphyletic. It includes families } \\
\text { placed in Pelagiaria and Eupercaria. }\end{array}$ \\
\hline Syngnatharia & Not classified by NGW & $\begin{array}{l}\text { A robust clade (series) including } 10 \text { families in the order } \\
\text { Syngnathiformes, as classified herein. }\end{array}$ \\
\hline Syngnathiformes & Includes 10 families herein and eight in NGW & $\begin{array}{l}\text { Exclusion of Mullidae and Callionymoidei renders } \\
\text { Syngnathiformes paraphyletic. }\end{array}$ \\
\hline Aulostomoidei & Not classified herein & Not monophyletic. \\
\hline
\end{tabular}


Table 1 Remarkable differences for ordinal or supraordinal taxa between JS Nelson, T Grande and MVH Wilson's (NGW [42]) classification and the update proposed herein. The circumscription of other orders may also differ due to variations in family validation (see Table 2) or due to inclusion of fossil taxa in NGW. Differences in taxonomic ranks and endings are considered minor and thus are not listed herein. NEL: [41] (Continued)

\begin{tabular}{ll}
\hline Callionymiformes & $\begin{array}{l}\text { Suborder (Callionymoid } \\
\text { herein }\end{array}$ \\
Anabantaria & Not classified by NGW \\
Indostomoidei & Not classified by NGW \\
Nandoidei & Not classified by NGW \\
Carangaria & Not classified by NGW
\end{tabular}

Istiophoriformes

Belonoidei/Exocoetoidei

Eupercaria

Gerreiformes

Acanthuriformes

Acanthuroidei and Sciaenoidei

Moroniformes/Ephippiformes

Spariformes

Chaetodontiformes

Lobotiformes

Lutjaniformes

Priacanthiformes

Uranoscopiformes

Moloidei

Triacanthodoidei

Ostracioidea/Ostracioide

Pempheriformes

Centrarchiformes

Perciformes
Includes two families herein and three in NGW

Exocoetoidei sensu NGW; Belonoidei herein

Not classified by NGW

Not classified by NGW

Includes three families herein and five in NGW

Not classified herein

Moroniformes in NGW (three families) and Ephippiformes herein (two families)

Includes three families herein and six in NGW

Not classified by NGW

Not classified by NGW

Not classified by NGW

Not classified by NGW

Not classified by NGW

Not classified by NGW

Not classified by NGW

Spelling

Not classified by NGW

Not classified by NGW

Includes 61 families herein and 62 in NGW (but with very different circumscriptions)
Recognition of Callionymiformes as a separate order renders Syngnathiformes paraphyletic.

A robust clade (series) including the orders Synbranchiformes (including Indostomidae) and Anabantiformes.

Indostomidae is not included in Synbranchiformes by NGW; exclusion of this family renders the order (and component suborders) non-monophyletic.

The order Anabantiformes in classified in three suborders herein. This scheme is robust to phylogenetic uncertainity.

A robust clade (series) including the orders Istiophoriformes, Carangiformes, Pleuronectiformes and several families listed as order-level incertae sedis.

Inclusion of Sphyraenidae renders Istiophoriformes non-monophyletic.

Belonoidei is the name-bearer.

A robust clade (series) including at least 17 orders and 161 families. The order Perciformes belongs in this clade.

Includes the family Gerreidae, which is sister to all other eupercarians (listed under Perciformes in NGW)

Inclusion of Emmelichthyidae and Sciaenidae renders Acanthuriformes non-monophyletic.

See comment under Acanthuriformes above.

Our results do not support a close relationship between Moronidae and Drepaneidae + Ephippidae.

Inclusion of Callanthiidae, Lobotidae (including Datnioididae) and Sillaginidae renders Spariformes non-monophyletic.

A robust clade (order) including the families Chaetodontidae and Leiognathidae.

A robust clade (order) including the families Hapalogenyidae, Datnioididae and Lobotidae (listed in Spariformes or Perciformes in NGW).

A robust clade (order) including the families Lutjanidae and Haemulidae (listed under Perciformes in NGW).

A robust clade (order) including the families Priacanthidae and Cepolidae (listed under Perciformes in NGW).

A robust clade (order) including the families Ammodytidae, Cheimarrichthyidae, Pinguipedidae and Uranoscopidae (listed under Trachiniformes in NGW).

Placement of Molidae in Tetraodontoidei often results in the non-monophyly of this suborder. The subordinal classification for Tetraodontiformes is robust to phylogenetic uncertainty

Placement of Triacanthodidae in Triacanthoidei often results in the non-monophyly of this suborder. The subordinal classification for Tetraodontiformes is robust to phylogenetic uncertainty

NGW recognize the "Suborder Ostracioidea", but the appropriate ending for the rank suborder is "-iodei."

A robust clade (order) including 17 families (most listed under Perciformes in NGW).

A robust clade (order) including five suborders and 18 families (most listed under Perciformes in NGW).

Our definition of Perciformes is monophyletic; NGW maintain the status quo by treating Perciformes as a taxonomic waste basket (polyphyletic). 
Table 1 Remarkable differences for ordinal or supraordinal taxa between JS Nelson, T Grande and MVH Wilson's (NGW [42]) classification and the update proposed herein. The circumscription of other orders may also differ due to variations in family validation (see Table 2) or due to inclusion of fossil taxa in NGW. Differences in taxonomic ranks and endings are considered minor and thus are not listed herein. NEL: [41] (Continued)

\begin{tabular}{|c|c|c|}
\hline Percoidei & Includes three families herein and 46 in NGW & $\begin{array}{l}\text { Our definition of Percoidei is monophyletic; NGW maintain the status } \\
\text { quo by treating Percoidei as a taxonomic waste basket (polyphyletic). }\end{array}$ \\
\hline Serranoidei & Not classified by NGW & Includes Serranidae. \\
\hline Bembropoidei & Not classified by NGW & Includes Bembropidae. \\
\hline Notothenioidei & Includes nine families herein and eight in NGW & $\begin{array}{l}\text { The family Percophidae is a member of Notothenioidei herein } \\
\text { [following 242], whereas in NGW it belongs in Trachiniformes. }\end{array}$ \\
\hline Scorpaeniformes & $\begin{array}{l}\text { Includes several families in NGW that are part of } \\
\text { four different perciform suborders herein }\end{array}$ & $\begin{array}{l}\text { Recognition of Scorpaeniformes as a separate order renders } \\
\text { Perciformes non-monophyletic. }\end{array}$ \\
\hline Gasterosteoidei/Gasterosteales & $\begin{array}{l}\text { Gasterosteoidei (suborder of Scorpaeniformes) in } \\
\text { NGW and Gasterosteales (suborder of } \\
\text { Perciformes) herein }\end{array}$ & $\begin{array}{l}\text { Gasterosteales herein is similar to Gasterosteoidei sensu NGW, } \\
\text { except that the former excludes Indostomidae (classified under } \\
\text { Synbranchiformes herein). }\end{array}$ \\
\hline Ceratodontoidei & Not classified by NGW & Classified by NEL. \\
\hline Lepidosirenoidei & Not classified by NGW & $\begin{array}{l}\text { Highlights sister-group relationship between African and South } \\
\text { American lungfishes (see also NEL). }\end{array}$ \\
\hline
\end{tabular}

included in the Series Carangaria, Ovalentaria, or Eupercaria remains uncertain due to either poor phylogenetic resolution or data unavailability. We therefore list these families as incertae sedis within each of these groups (Carangaria, Ovalentaria, or Eupercaria) awaiting new phylogenetic evidence to clarify their ordinal status. Twenty-three non-monophyletic families according to the framework phylogeny (Fig. 2) are recognized in this version (vs. 40 in version 1): Acropomatidae, Alepocephalidae, Bathydraconidae, Bathymasteridae, Chaenopsidae, Cheilodactylidae, Chlorophthalmidae, Clupeidae, Gempylidae, Grammatidae, Hemiramphidae, Ipnopidae, Labrisomidae, Nototheniidae, Paralepididae, Phosichthyidae, Scombridae, Scopelarchidae, Scorpaenidae, Stichaeidae, Synodontidae, Trachichthyidae, and Zenarchopteridae (see details below). Non-monophyly in these cases may be the result of poor resolution. These families are validated for stability purposes until additional evidence elucidating their status becomes available.

We cite sources for morphological synapomorphies for clades we have found in the literature. But there are caveats: (i) the original author/s may have polarized their characters using outgroups that are different than those appearing in this classification; (ii) we note that some suites of synapomorphies were meant for a more inclusive group than we recognize due to exclusion of one or more members of the previously recognized clade; and (iii) in some cases there is obvious conflict between morphological and molecular analyses. Our purpose is not to confirm these synapomorphies or to reject morphological conclusions that differ from our results. Rather, we seek to call attention to previously accomplished morphological analyses and to point out, where we can, conflicts and consilience between morphological and molecular studies, indicating groups that lack morphological support. See Additional file $3 \mathrm{~A}$ for an indented and comment-free version of the classification.

Megaclass Osteichthyes (= extant Euteleostomi)

Morphological synapomorphies: see G Arratia and HP Schultze [114], P Janvier [115], P Ahlberg [116], M Zhu and HP Schultze [117], M Zhu, X Yu and P Janvier [118].

Superclass Actinopterygii (100\%)

Morphological synapomorphies: see C Patterson [119], MI Coates [120], H-P Schultze and SL Cumbaa [121], R Cloutier and G Arratia [122], K Mickle [123].

Class Cladistia (100\%)

Morphological synapomorphies: see E Jarvik [124], R Britz and P Bartsch [125], AB Ward and NJ Kley [126].

Comments: polypteriforms or bichirs present a combination of characters that have led to their former identification as members of the Sarcopterygii (placed within Brachyopterygii). This view has changed since the implementation of explicit phylogenetic analyses, demonstrating that bichirs belong in Actinopterygii (e.g., [127]). Recent molecular analyses using the taxa necessary to assess the placement of bichirs (e.g., chondrichthyans, sarcopterygians and actinopterygians) have confirmed this view $[8,9]$.

\section{Order Polypteriformes}

Morphological synapomorphies: same as Cladistia (extant taxa only).

Polypteridae

\section{Class Actinopteri (100\%)}

Morphological synapomorphies: few morphological studies provide support for this clade; e.g., $\mathrm{R}$ Lund and C Poplin [128] and G-H Xu, K-Q Gao and JA Finarelli [129]. Note, however, that $\mathrm{R}$ Lund and $\mathrm{C}$ Poplin [128] did not include in their study fossil and/ 
Table 2 Differences in the recognition of families between JS Nelson, T Grande and MVH Wilson's (NGW [42]) and R Van Der Laan, WN Eschmeyer and R Fricke's(vdLE [62]) classifications and the update proposed herein. Taxa are listed in alphabetic order. NEL: [41]

\begin{tabular}{|c|c|c|c|}
\hline Family & Differences with NGW & Differences with vdLE & Justification/Remarks \\
\hline "Cyclopsettidae" & $\begin{array}{l}\text { Provisionally recognized as } \\
\text { "Cyclopsettidae" herein }\end{array}$ & $\begin{array}{l}\text { Provisionally recognized as } \\
\text { "Cyclopsettidae" herein }\end{array}$ & Awaits formal description; see [259] \\
\hline "Pantanodontidae" & $\begin{array}{l}\text { Provisionally recognized as } \\
\text { "Pantanodontidae" herein }\end{array}$ & $\begin{array}{l}\text { Provisionally recognized as } \\
\text { "Pantanodontidae" herein }\end{array}$ & Awaits formal description; see [283] \\
\hline "Percalatidae" & $\begin{array}{l}\text { Provisionally recognized as } \\
\text { "Percalatidae" herein }\end{array}$ & $\begin{array}{l}\text { Provisionally recognized as } \\
\text { "Percalatidae" herein }\end{array}$ & Awaits formal description; see text \\
\hline "Percophidae" & $\begin{array}{l}\text { Provisionally recognized as } \\
\text { "Percophidae" herein }\end{array}$ & $\begin{array}{l}\text { Provisionally recognized as } \\
\text { "Percophidae" herein }\end{array}$ & $\begin{array}{l}\text { Awaits formal description; lineage in } \\
\text { Pempheriformes not related to Percophidae } \\
\text { (Perciformes); see also [242] }\end{array}$ \\
\hline "Rivulidae" & $\begin{array}{l}\text { Provisionally recognized as "Rivulidae" } \\
\text { herein; Rivulidae in NGW }\end{array}$ & - & $\begin{array}{l}\text { The name Rivulidae is preoccupied in } \\
\text { Lepidoptera (see vdLE) }\end{array}$ \\
\hline Abyssocottidae & _- & Synonym of Cottidae herein & Following [345] \\
\hline Acheilognathidae & Subfamily of Cyprinidae in NGW & Subfamily of Cyprinidae in vdLE & Following [102] \\
\hline Achiropsettidae & Synonym of Rhombosoleidae herein & $\begin{array}{l}\text { Synonym of Rhombosoleidae } \\
\text { herein }\end{array}$ & $\begin{array}{l}\text { Lumped due to phylogenetic nestedness } \\
\text { [e.g., 259] }\end{array}$ \\
\hline Anotopteridae & Synonym of Paralepididae in NGW & _- & Following [216] \\
\hline Aphyonidae & Synonym of Bythitidae herein & Synonym of Bythitidae herein & Following [231] \\
\hline Apistidae & Subfamily of Scorpaenidae in NGW & - & Following vdLE and [231] \\
\hline Arapaimidae & - & $\begin{array}{l}\text { Synomym of Osteoglossidae } \\
\text { herein }\end{array}$ & Following [161] \\
\hline Atherionidae & $\begin{array}{l}\text { Synonym (subfamily) of } \\
\text { Atherinopsidae herein }\end{array}$ & - & Following [274] \\
\hline Bathygadidae & - & $\begin{array}{l}\text { Synonym (subfamily) of } \\
\text { Macrouridae in vdLE }\end{array}$ & Following [223] \\
\hline Bathylaconidae & Synonym of Alepocephalidae herein & - & Following vdLE \\
\hline Bathylutichthyidae & Synonym of Psychrolutidae herein & $\begin{array}{l}\text { Synonym of Psychrolutidae } \\
\text { herein }\end{array}$ & Following [345] \\
\hline Bathysauropsidae & Subfamily of Ipnopidae in NGW & - & Following [216] \\
\hline Bedotiidae & Subfamily of Melanotaeniidae in NGW & - & Following . [274] and vdLE \\
\hline Bembropidae & Subfamily of Percophidae in NGW & $\begin{array}{l}\text { Subfamily of Percophidae in } \\
\text { vdLE }\end{array}$ & Following [58] \\
\hline Botiidae & - & Subfamily of Cobitidae in vdLE & Following $[102,185]$ \\
\hline Bryconidae & Subfamily of Characidae in NGW & - & $\begin{array}{l}\text { Following }[83,101] \\
\text { and vdLE }\end{array}$ \\
\hline Butidae & _- & Subfamily of Eleotridae in vdLE & Following $[241,242]$ \\
\hline Caesionidae & Synonym of Lutjanidae herein & Synonym of Lutjanidae herein & Lumped due to phylogenetic nestedness \\
\hline Carapidae & Synonym of Ophidiidae herein & Synonym of Ophidiidae herein & Lumped due to phylogenetic nestedness \\
\hline Centracanthidae & - & Synonym of Sparidae herein & Following $[92,298]$ \\
\hline Chalceidae & Omitted by NGW and NEL & - & $\begin{array}{l}\text { Following }[83,101] \\
\text { and vdLE }\end{array}$ \\
\hline Cheimarrichthyidae & Spelled Cheimarrhichthyidae in NGW & - & Following vdLE \\
\hline Colocongridae & Synomym of Derichthyidae in NGW & $\begin{array}{l}\text { Synomym of Derichthyidae } \\
\text { herein }\end{array}$ & Following [158] \\
\hline Comephoridae & - & Synonym of Cottidae herein & Following [345] \\
\hline Congrogadidae & $\begin{array}{l}\text { Subfamily of Pseudochromidae in } \\
\text { NGW }\end{array}$ & $\begin{array}{l}\text { Subfamily of Pseudochromidae } \\
\text { in vdLE }\end{array}$ & Following our results and [268] \\
\hline Cottocomephoridae & - & $\begin{array}{l}\text { Subfamily of Cyprinidae in } \\
\text { NGW }\end{array}$ & Following [345] \\
\hline Danionidae & Subfamily of Cyprinidae in NGW & Subfamily of Cyprinidae in vdLE & Following [102] \\
\hline
\end{tabular}


Table 2 Differences in the recognition of families between JS Nelson, T Grande and MVH Wilson's (NGW [42]) and R Van Der Laan, WN Eschmeyer and R Fricke's(vdLE [62]) classifications and the update proposed herein. Taxa are listed in alphabetic order. NEL: [41] (Continued)

\begin{tabular}{|c|c|c|c|}
\hline Datnioididae & Synonym of Lobotidae in NGW & - & Following [92] \\
\hline Dinematichthyidae & $\begin{array}{l}\text { Synonym of Brosmophycinae, a } \\
\text { subfamily of Bythitidae in NGW }\end{array}$ & - & Following [231] \\
\hline Dussumieriidae & - & Synonym of Clupeidae herein & Following [171] \\
\hline Elassomatidae & Subfamily of Centrarchidae in NGW & - & Following vdLE and our results \\
\hline Ereuniidae & - & $\begin{array}{l}\text { Synonym of Rhamphocottidae } \\
\text { herein }\end{array}$ & Following [345] \\
\hline Eulophiidae & - & Synonym of Zoarcidae in vdLE & Following [344] \\
\hline Gaidropsaridae & Subfamily of Gadidae in NGW & Subfamily of Lotidae in vdLE & $\begin{array}{l}\text { Formerly a subfamily of Lotidae; raised to } \\
\text { family level in version } 3\end{array}$ \\
\hline Gastromyzontidae & - & Subfamily of Balitoridae in vdLE & Following $[102,186]$ \\
\hline Girellidae & Subfamily of Kyphosidae in NGW & $\begin{array}{l}\text { Subfamily of Kyphosidae in } \\
\text { vdLE }\end{array}$ & $\begin{array}{l}\text { Following our results and several recent } \\
\text { studies }[186,321,324,325,327]\end{array}$ \\
\hline Gobionellidae & - & Junior synonym of Oxudercidae & See NGW \\
\hline Gobionidae & Subfamily of Cyprinidae in NGW & Subfamily of Cyprinidae in vdLE & Following [102] \\
\hline Hapalogenyidae & Spelled Hapalogeniidae in NGW & - & See vdLE and [92] \\
\hline Hemerocoetidae & Subfamily of Percophidae in NGW & $\begin{array}{l}\text { Subfamily of Percophidae in } \\
\text { vdLE }\end{array}$ & Following [242] \\
\hline Hemitripteridae & _- & Synonym of Agonidae herein & Following [345] \\
\hline Iguanodectidae & Subfamily of Characidae in NGW & - & Following $[83,101]$ \\
\hline Jordaniidae & - & Subfamily of Cottidae in vdLE & Following [345] \\
\hline Kraemeriidae & _- & Synonym of Gobiidae herein & Following $[241,242]$ \\
\hline Kryptoglanidae & Synonym of Siluridae in NGW & - & Following vdLE and [345] \\
\hline Latidae & Synonym of Centropomidae herein & $\begin{array}{l}\text { Synonym of Centropomidae } \\
\text { herein }\end{array}$ & Following $[82,262]$ \\
\hline Leptobarbidae & Subfamily of Cyprinidae in NGW & Subfamily of Cyprinidae in vdLE & Following [102] \\
\hline Leptobramidae & Omitted by NGW; listed in erratum & - & _- \\
\hline Leptochilichthyidae & - & $\begin{array}{l}\text { Synomym of Alepocephalidae } \\
\text { herein }\end{array}$ & Following $[173,174]$ \\
\hline Lestidiidae & - & Tribe of Paralepididae in vdLE & Following [217] and NGW \\
\hline Leuciscidae & Subfamily of Cyprinidae in NGW & Subfamily of Cyprinidae in vdLE & Following [102] \\
\hline Lotidae & - & Synonym of Gadidae herein & Following NGW \\
\hline Macroramphosidae & $\begin{array}{l}\text { Synonym (subfamily) of Centriscidae } \\
\text { herein }\end{array}$ & - & Following vdLE \\
\hline Macruronidae & - & $\begin{array}{l}\text { Synonym of Merlucciinae in } \\
\text { vdLE }\end{array}$ & Following [223] \\
\hline Microdesmidae & - & Synonym of Gobiidae herein & Following $[241,242]$ \\
\hline Microcanthidae & Subfamily of Kyphosidae in NGW & $\begin{array}{l}\text { Subfamily of Kyphosidae in } \\
\text { vdLE }\end{array}$ & $\begin{array}{l}\text { Following several recent studies } \\
{[186,321,324,325,327]}\end{array}$ \\
\hline Milyeringidae & - & Subfamily of Eleotridae in vdLE & Following $[241,242]$ \\
\hline Neosebastidae & Subfamily of Scorpaenidae in NGW & - & Following vdLE \\
\hline Niphonidae & Tribe of Serranidae in NGW & Synonym of Serranidae in vdLE & Following [58] \\
\hline Notocheiridae & Subfamily of Atherinopsidae herein & $\begin{array}{l}\text { Subfamily of Atherinopsidae } \\
\text { herein }\end{array}$ & Following [274] \\
\hline Odacidae & Synonym of Labridae herein & Synonym of Labridae herein & Lumped due to phylogenetic nestedness \\
\hline Olyridae & - & Synomym of Bagridae herein & Following [198] \\
\hline Omosudidae & Synonym of Alepisauridae in NGW & - & Following [216] \\
\hline
\end{tabular}


Table 2 Differences in the recognition of families between JS Nelson, T Grande and MVH Wilson's (NGW [42]) and R Van Der Laan, WN Eschmeyer and R Fricke's(vdLE [62]) classifications and the update proposed herein. Taxa are listed in alphabetic order. NEL: [41] (Continued)

\begin{tabular}{|c|c|c|c|}
\hline Ostracoberycidae & Omitted by NGW; valid in NEL & - & Following vdLE \\
\hline Oxudercidae & - & Subfamily of Gobiidae in vdLE & Following $[241,242]$ \\
\hline Paedocyprididae & Synonym of Danioninae in NGW & $\begin{array}{l}\text { Synonym of Danioninae in } \\
\text { vdLE }\end{array}$ & Following $[81,102]$ \\
\hline Parabembridae & Synonym of Bembridae in NGW & - & Following vdLE and [357] \\
\hline Parabrotulidae & Synonym of Bythitidae herein & Synonym of Bythitidae herein & Following [232] \\
\hline Paralichthodidae & - & $\begin{array}{l}\text { Subfamily of Pleuronectidae in } \\
\text { vdLE }\end{array}$ & Following $[265,266]$ \\
\hline Parascorpididae & $\begin{array}{l}\text { Omitted by NGW; subfamily of } \\
\text { Kyphosidae in NEL }\end{array}$ & - & Following vdLE \\
\hline Perciliidae & Synonym of Percichthyidae herein & $\begin{array}{l}\text { Synonym of Percichthyidae } \\
\text { herein }\end{array}$ & Lumped due to phylogenetic nestedness \\
\hline Perryenidae & $\begin{array}{l}\text { Not recognized by NGW; Perryena } \\
\text { listed under Congiopodidae }\end{array}$ & - & Following [339] \\
\hline Phractolaemidae & - & Synomym of Kneriidae herein & Following [21] \\
\hline Phycidae & Subfamily of Gadidae in NGW & - & Following [223] \\
\hline Plectrogeniidae & Subfamily of Scorpaenidae in NGW & - & Following [336] and vdLE \\
\hline Poecilopsettidae & - & $\begin{array}{l}\text { Subfamily of Pleuronectidae in } \\
\text { vdLE }\end{array}$ & Following $[265,266]$ \\
\hline Polynemidae & Omitted by NGW; listed in erratum & - & - \\
\hline Prototroctidae & $\begin{array}{l}\text { Synonym (subfamily) of Retropinnidae } \\
\text { herein }\end{array}$ & - & Following vdLE \\
\hline Pseudomugilidae & Subfamily of Melanotaeniidae in NGW & - & Following [274] and vdLE \\
\hline Psilorhynchidae & - & $\begin{array}{l}\text { Synonym of Labeoninae in } \\
\text { vdLE }\end{array}$ & Following [102] \\
\hline Ranicipitidae & - & $\begin{array}{l}\text { Synonym (tribe) of Gadidae in } \\
\text { vdLE }\end{array}$ & Following [223] \\
\hline Rhombosoleidae & - & $\begin{array}{l}\text { Subfamily of Pleuronectidae in } \\
\text { vdLE }\end{array}$ & Following $[265,266]$ \\
\hline Scaridae & Synonym of Labridae herein & Synonym of Labridae herein & Lumped due to phylogenetic nestedness (e.g., [267] \\
\hline Schindleriidae & _ & Synonym of Gobiidae herein & Following $[241,242]$ \\
\hline Scomberesocidae & Synonym of Belonidae herein & Synonym of Belonidae herein & Lumped due to phylogenetic nestedness (e.g., [279] \\
\hline Scorpaenichthyidae & - & Subfamily of Cottidae in vdLE & Following [345] \\
\hline Scorpididae & Subfamily of Kyphosidae in NGW & $\begin{array}{l}\text { Subfamily of Kyphosidae in } \\
\text { vdLE }\end{array}$ & $\begin{array}{l}\text { Following several recent studies } \\
{[186,321,324,325,327]}\end{array}$ \\
\hline Sebastidae & Subfamily of Scorpaenidae in NGW & - & Following vdLE \\
\hline Setarchidae & Subfamily of Scorpaenidae in NGW & - & Following vdLE \\
\hline Sinipercidae & - & $\begin{array}{l}\text { Subfamily of Percichthyidae in } \\
\text { vdLE }\end{array}$ & Following [317] \\
\hline Steindachneriidae & - & $\begin{array}{l}\text { Subfamily of Merlucciidae in } \\
\text { vdLE }\end{array}$ & Following [223] \\
\hline Sudidae & - & $\begin{array}{l}\text { Synonym of Paralepididae in } \\
\text { vdLE }\end{array}$ & Following [216] \\
\hline Sundadanionidae & Synonym of Danioninae in NGW & $\begin{array}{l}\text { Synonym of Danioninae in } \\
\text { vdLE }\end{array}$ & Following [102] \\
\hline Sundasalangidae & - & Synomym of Clupeidae herein & Following [171] \\
\hline Symphysanodontidae & Omitted by NGW; valid in NEL & _ & Following vdLE \\
\hline
\end{tabular}


Table 2 Differences in the recognition of families between JS Nelson, T Grande and MVH Wilson's (NGW [42]) and R Van Der Laan, WN Eschmeyer and R Fricke's(vdLE [62]) classifications and the update proposed herein. Taxa are listed in alphabetic order. NEL: [41] (Continued)

\begin{tabular}{|c|c|c|c|}
\hline Synanceiidae & Subfamily of Scorpaenidae in NGW & - & Following vdLE \\
\hline Tanichthyidae & Synonym of Danioninae in NGW & $\begin{array}{l}\text { Synonym of Xenocypridinae in } \\
\text { vdLE }\end{array}$ & Following [102] \\
\hline Telmatherinidae & Subfamily of Melanotaeniidae in NGW & - & Following [274] and vdLE \\
\hline Tetrarogidae & Subfamily of Scorpaenidae in NGW & _- & Following vdLE \\
\hline Tincidae & Subfamily of Cyprinidae in NGW & Subfamily of Cyprinidae in vdLE & Following [102] \\
\hline Trachyrincidae & - & $\begin{array}{l}\text { Synonym (subfamily) of } \\
\text { Macrouridae in vdLE }\end{array}$ & Following [223] \\
\hline Triportheidae & $\begin{array}{l}\text { Synonym of Iguanodectinae, a } \\
\text { subfamily of Characidae in NGW }\end{array}$ & - & Following $[83,101]$ \\
\hline Xenisthmidae & - & Synonym of Eleotridae herein & Following $[241,242]$ \\
\hline Xenocyprididae & Subfamily of Cyprinidae in NGW & Subfamily of Cyprinidae in vdLE & Following [102] \\
\hline Zanclorhynchidae & Synonym of Congiopodidae in NGW & _ & Following vdLE \\
\hline Zaniolepididae & - & $\begin{array}{l}\text { Subfamily of Hexagrammidae } \\
\text { in vdLE }\end{array}$ & Following [345] \\
\hline
\end{tabular}

or extant members of chondrosteans and neopterygians. Likewise, G-H Xu, K-Q Gao and JA Finarelli [129] used in their phylogenetic analyses the Cheirolepis as an outgroup, not as part of the ingroup, and their coding of Polypterus does not consider the homologization problems that polypteriforms versus other actinopterygians present, as highlighted by $\mathrm{R}$ Cloutier and $\mathrm{G}$ Arratia [122].

Comment: Although morphological studies on Actinopteri are scarce, the currently accepted branching of chondrosteans, holosteans and teleosts (Fig. 1) is supported by several molecular studies (e.g., [8, 10, 11, 88-90]).

Subclass Chondrostei (100\%)

Morphological synapomorphies: see G Arratia and HP Schultze [114], L Grande and WE Bemis [130], WE Bemis, EK Findeis and L Grande [131].

\section{Order Acipenseriformes}

Morphological synapomorphies: same as Chondrostei (extant taxa only).

Acipenseridae

Polyodontidae

Subclass Neopterygii (100\%)

Morphological synapomorphies: see C Patterson and DE Rosen [47], BG Jamieson [132], L Grande [133], A López-Arbarello [134].

Infraclass Holostei (100\%)

Morphological synapomorphies: L Grande [133].

Comment: Holostei was readopted by L Grande [133], after several decades of dismissal in ichthyology. Monophyly of Holostei has been also confirmed by several molecular studies (e.g., [8-10, 135]).

Order Amiiformes (= extant Halecomorphi).

Morphological synapomorphies: see L Grande and WE Bemis [16], G Arratia [136], G Arratia [137].
Comment: it should be noted that the three synapomorphies proposed by L Grande and WE Bemis [16] for amiiforms become homoplasies when other primitive teleosts, such as Triassic pholidophorids, are included in the phylogenetic analysis (see [136, 137]).

Amiidae

Order Lepisosteiformes (= extant Ginglymodi) (100\%) Morphological synapomorphies: see EO Wiley [138], L Grande [133].

Lepisosteidae

Infraclass Teleostei (100\%)

Morphological synapomorphies: see G Arratia [17], G Arratia [136], G Arratia [46], G Arratia [137]. See also EO Wiley and GD Johnson [57].

Comment: Teleosteomorpha (or total group teleost including stem members), apomorphy-based Teleostei, and crown group Teleocephala in MCC de Pinna [139] are treated here as synonyms when only extant taxa are considered. However, we are aware that these three groups are diagnosed by different sets of synapomorphies (see G Arratia [46], G Arratia [137]). R Britz [140] criticism of the use of Teleosteomorpha and Teleocephala in his book review of Fishes of the World [42] lacks solid ground because no paleontologist or neoicthyologist is confused with the meaning of one name or the other, particularly when the concept followed is being explained. Nevertheless, we agree that the presentation of Teleocephala in JS Nelson, T Grande and MVH Wilson [42] is confusing and that the list of synapomorphies presented to support Teleocephala sensu MCC de Pinna [139] is a combination of three concepts.

Megacohort Elopocephalai sensu G Arratia [17] (100\%). Morphological synapomorphies: see G Arratia [17].

Cohort Elopomorpha (100\%) 
Morphological synapomorphies: see G Arratia [17], G Arratia [136]; see also comments below.

Comments: while divergence of Elopomorpha at the base of teleosts is counter to the prevailing view that the Osteoglossomorpha represents the earliest branching teleost lineage [36, 40, 47, 141-143], substantial morphological $[17,25,66,136,144-152]$ and molecular $[8,9,153,154]$ evidence favors elopomorphs as the first diverging teleosts. A more recent phylogenomic analysis based on 418 orthologous genes [155] obtained support for yet another topology - a sister-group relationship between elopomorphs and osteoglossomorphs. That study, however, has a limited taxonomic scope (12 taxa), with crucial lineages that bisect long branches missing (e.g., Hiodon, clupeiforms and Lepidogalaxias). Placement of Elopomorpha as sister to the remaining teleosts is herein maintained (i.e., it is congruent with the phylogeny presented in Figs. 1 and 2).

Order Elopiformes (100\%)

Morphological synapomorphies: see PL Forey [156], GD Johnson and R Britz [157].

Elopidae

Megalopidae

Order Albuliformes (95\%)

Morphological synapomorphies: see PL Forey [156].

Albulidae

Order Notacanthiformes (92\%)

Morphological synapomorphies: see PL Forey [156].

Halosauridae

Notacanthidae

Order Anguilliformes (100\%)

Morphological synapomorphies: see PL Forey [156], GD Johnson, H Ida, J Sakaue, T Sado, T Asahida and M Miya [158], GD Johnson and R Britz [157].

Comment: suborders recognized in EO Wiley and GD Johnson [57] based on previous work cited therein are significantly incongruent with the clades obtained in this analysis; thus, no subordinal classification is proposed.

Anguillidae

Congridae

Eurypharyngidae

Muraenesocidae

Muraenidae

Nemichthyidae

Ophichthidae

Saccopharyngidae

Serrivomeridae

Not examined: Chlopsidae, Cyematidae, Derichthyidae

(including Colocongridae [158]), Heterenchelyidae,

Monognathidae, Moringuidae, Myrocongridae,

Nettastomatidae, Protanguillidae, Synaphobranchidae.

Megacohort Osteoglossocephalai (= Osteoglossocephala sensu G Arratia [17]) (100\%).
Morphological synapomorphies: see G Arratia [17], EJ Hilton [159], J-Y Zhang [160], MVH Wilson and AM Murray [161].

Supercohort Osteoglossomorpha sensu G Arratia [17]

Morphological synapomorphies: see G Arratia [17], G Arratia [46], G Arratia [137]; see also comments under Elopomorpha above.

Comments: previous versions of the classification validated the supercohort Osteoglossocephala as well as the cohort Osteoglossomorpha, which were redundant in content. For simplicity and to avoid confusion -Osteoglossocephala sensu G Arratia [17] is the same as Osteoglossocephalai here and in previous versions, but not the same as Osteoglossocephala in previous versions - we now name this supercohort Osteoglossomorpha, but this change also means that the endings for the ranks cohort and supercohort are interchangeable.

Order Hiodontiformes (100\%)

Morphological synapomorphies: see EJ Hilton [159], JY Zhang [160], MVH Wilson and AM Murray [161].

Hiodontidae

Order Osteoglossiformes (42\%)

Morphological synapomorphies: see EJ Hilton [159], J-

Y Zhang [160], MVH Wilson and AM Murray [161].

Comment: Osteoglossidae includes Arapaima and Heterotis, formerly in Arapaimidae [161].

Gymnarchidae

Mormyridae

Notopteridae

Osteoglossidae

Pantodontidae

Supercohort Clupeocephala sensu G Arratia [48] (100\%) Morphological synapomorphies: see G Arratia [48].

Cohort Otomorpha (= Otocephala, Ostarioclupeomorpha) (92\%).

Morphological synapomorphies: Morphological characters supporting Otomorpha (but excluding Alepocephalidae) can be found in G Arratia [45], G Arratia [17], G Arratia [48], EO Wiley and GD Johnson [57].

Comments: Morphological support exists for the cohort Otomorpha, including only the subcohorts Clupei and Ostariophysi. According to G Arratia [17, 45, 48], otomorphs (her ostarioclupeomorphs) are clupeocephalans in which primitively there is an ankyloses or fusion between the mesial extrascapula and parietal alone or parietal and supraoccipital; hypurals 1 and 2 not joined by cartilage in any stage of growth, and autopalatine ossified early in ontogeny. Additionally, the presence of a modified uroneural or pleurostyle was listed as a potential synapomorphy because a pleurostyle is found in all extant otomorphs, but is absent in some of the primitive fossils of Clupei and Denticipitidae. Further research [48] re- 
interpreted the early ossification of the autopalatine as a clupeocephalan character, and EO Wiley and GD Johnson [57] listed a few potential synapomorphies. R Britz [140] considered the support of Otomorpha as "meagre." To disprove the first character mentioned above, he used the condition present in advanced gonorynchiforms, the paedomorphic kneriids Cromeria and Grasseichthys, which lack parietal bones and consequently this loss represents a further transformation of the otomorph synapomorphy within the clade. The second character is questioned based on a supposedly cartilaginous connection between hypurals 1 and 2 in early developmental stages of the characiform Salminus, a connection that is not mentioned in the publication, but whose presence is unclear considering the unsatisfactory quality of preparation of the illustrated specimens in SMT Mattox, $\mathrm{R}$ Britz and M Toledo-Piza [162]. Such connection has not been described (or illustrated) in larvae of other otomorphs (see for instance $[147,163-166])$.

Subcohort Clupei (= Clupeomorpha) (100\%)

Morphological synapomorphies: see L Grande [167].

Order Clupeiformes (100\%)

Morphological synapomorphies: same as Clupei.

\section{Suborder Denticipitoidei}

Morphological synapomorphies: L Grande [167], F Di Dario and MCC de Pinna [168], MCC de Pinna and F Di Dario [169].

\section{Denticipitidae}

\section{Suborder Clupeoidei (98\%)}

Morphological synapomorphies: L Grande [167], F Di Dario and MCC de Pinna [168], MCC de Pinna and F Di Dario [169].

Comment: family-level groupings may require major revision; Pristigasteridae, Chirocentridae and Engraulidae are supported by other molecular studies, but not Clupeidae [170, 171]; five well-supported lineages may become new families [171]. The family Sundasalangidae is no longer recognized because Sundasalanx is nested within Clupeidae (see also [172]). Clupeidae also includes the round herrings (subfamily Dussumieriinae [171]), sometimes placed in the family Dussumieriidae [62].

Chirocentridae

Clupeidae (not monophyletic in Fig. 2).

Engraulidae

Pristigasteridae

Subcohort Alepocephali (37\%)

Morphological synapomorphies: see GD Johnson and C Patterson [49].

Comments: To the best of our knowledge, no morphological study has tested the molecular hypotheses that include the Alepocephaliformes as sister of Ostariophysi. However, as pointed out by JY Poulsen,
PR Møller, S Lavoué, SW Knudsen, M Nishida and M Miya [173] "prior to the major publication of Greenwood et al. (1966), the prevailing hypothesis placed the Alepocephaliformes (with or without the Bathylaconidae) and the Clupeiformes (named Clupeoidei at this time) close to each other, within a larger group including other so-called "basal" or "primitive" teleosts, i.e., the "Isospondyli" (Berg, 1940; Bertin and Arambourg, 1958; Gosline, 1960; Marshall, 1966). Greenwood et al. (1966) tentatively transferred the Alepocephaliformes within the order Salmoniformes, only because these authors could not find any character to separate them from the Salmoniformes. However, they admitted: "there is little critical anatomical information on the Alepocephalidae, and any decision concerning their position must therefore be considered tentative... much more research is needed before the status of the Alepocephaloidei is understood."'

\section{Order Alepocephaliformes}

Morphological synapomorphies: same as Alepocephali.

Comment: Alepocephalidae includes Bathylaco, placed in Bathylaconidae by JS Nelson, T Grande and MVH Wilson [42], and the former Leptochilichthyidae [173, 174]. The position of alepocephaliforms as the sister group to Ostariophysi is contrary to their more traditional placement in Euteleostomorpha (e.g., [49]). Their current placement in Otomorpha has been consistently obtained by other molecular studies (e.g., [173, 174]).

Alepocephalidae (not monophyletic in Fig. 2).

Platytroctidae

\section{Subcohort Ostariophysi (99\%)}

Morphological synapomorphies: see SV Fink and WL Fink [175], SV Fink and WL Fink [176].

Section Anotophysa (= Anotophysi) $(100 \%)$

Morphological synapomorphies: see SV Fink and WL Fink [175], FJ Poyato-Ariza, T Grande and R Diogo [177], T Grande and FJ Poyato-Ariza [178], MP Davis, G Arratia and TM Kaiser [21].

\section{Order Gonorynchiformes}

Morphological synapomorphies: same as Anotophysa.

Comment: suborders in Gonorynchiformes are no longer recognized. See also JS Nelson, T Grande and MVH Wilson [42]. The former Phractolaemidae is now listed as a subfamily in Kneriidae [21].

Gonorynchidae

Chanidae

Kneriidae

Section Otophysa (= Otophysi) (100\%)

Morphological synapomorphies: see SV Fink and WL Fink [175], SV Fink and WL Fink [176].

Comment: although most molecular studies (e.g., [72, 179]) are incongruent regarding otophysan interrelationships, our recent investigation of this question 
using genome-wide exon data coupled with a novel method for interrogating gene genealogies [101] provides overwhelming support for the null morphological hypothesis of SV Fink and WL Fink [175], which places the monophyletic characiforms sister to a clade including siluriforms and gymnotiforms. Three otophysan superorders (Cypriniphysae, Characiphysae and Siluriphysae) are now recognized. Their taxonomic composition is similar to that originally proposed by SV Fink and WL Fink [175], except that Characiphysae now contains a single order (Characiformes) following JS Nelson, T Grande and MVH Wilson [42].

\section{Superorder Cypriniphysae (92\%)}

Morphological synapomorphies: see SV Fink and WL Fink [175], SV Fink and WL Fink [176], PM Mabee, EA Grey, G Arratia, N Bogutskaya, A Boron, MM Coburn, KW Conway, S He, A Naseka, N Rios, et al. [180], KW Conway [181].

\section{Order Cypriniformes}

Morphological synapomorphies: same as Cypriniphysae.

Comments: recognition of suborders and families in Cypriniformes follows CC Stout, M Tan, AR Lemmon, EM Lemmon and JW Armbruster [102], which builds on WJ Chen and RL Mayden [182]. Note that the phylogenomic results by CC Stout, M Tan, AR Lemmon, EM Lemmon and JW Armbruster [102] differ from those derived from the analysis of morphological data (e.g., KW Conway [181], R Britz, K Conway and L Ruber [183]), in that the latter obtain a "Cobitoidea" sensu lato clade (including Gyrinocheilus, Catostomidae, and Cobitoidei sensu stricto), but there are relatively few characters that support that grouping and clade support is weak. This subordinal classification, with three suborders for "Cobitoidea", is robust to phylogenetic uncertainty. Nodal support values of suborders are from CC Stout, M Tan, AR Lemmon, EM Lemmon and JW Armbruster [102].

Suborder Gyrinocheiloidei (100\%)

Morphological synapomorphies: see DJ Siebert [184], KW Conway [181], PM Mabee, EA Grey, G Arratia, N Bogutskaya, A Boron, MM Coburn, KW Conway, S He, A Naseka, N Rios, et al. [180], R Britz, K Conway and L Ruber [183].

Gyrinocheilidae

Suborder Catostomoidei (100\%)

Morphological synapomorphies: see DJ Siebert [184], KW Conway [181], PM Mabee, EA Grey, G Arratia, N Bogutskaya, A Boron, MM Coburn, KW Conway, S He, A Naseka, N Rios, et al. [180], KW Conway [181], R Britz, K Conway and L Ruber [183].

Catostomidae

Suborder Cobitoidei (100\%)

Morphological synapomorphies: see KW Conway [181], R Britz, K Conway and L Ruber [183].
Comment: recognition of Botiidae and Gastromyzontidae follows WJ Chen, V Lheknim and RL Mayden [185] and M Kottelat [186], respectively.

Balitoridae

Botiidae

Cobitidae

Gastromyzontidae

Nemacheilidae

Vaillantellidae

Not examined: Barbuccidae, Ellopostomatidae,

Serpenticobitidae.

Suborder Cyprinoidei (100\%)

Morphological synapomorphies: see KW Conway [181], R Britz, K Conway and L Ruber [183].

Comment: Cyprinidae sensu lato (not monophyletic) is now split into multiple monophyletic families that are coherent with biogeography. The rogue placement of Esomus in molecular and morphological analyses (see [102]) suggest that this genus may represent a distinct cyprinoid lineage, which is provisionally retained within Danionidae [102]. Recognition of Xenocyprididae is based on L Yang, T Sado, M Vincent Hirt, E Pasco-Viel, M Arunachalam, J Li, X Wang, J Freyhof, K Saitoh, AM Simons, et al. [187] and CC Stout, M Tan, AR Lemmon, EM Lemmon and JW Armbruster [102].

Acheilognathidae

Cyprinidae

Danionidae

Gobionidae

Leuciscidae

Paedocyprididae

Sundadanionidae

Tanichthyidae

Xenocyprididae

Not examined: Leptobarbidae,

Psilorhynchidae, Tincidae.

Superorder Characiphysae (= Characiphysi) $(100 \%)$

Morphological synapomorphies: those listed for Characiformes in SV Fink and WL Fink [175], SV Fink and WL Fink [176], RP Vari [188].

Comment: circumscription of Characiphysae here and in JS Nelson, T Grande and MVH Wilson [42] differs from that of SV Fink and WL Fink [175]; see comment under Otophysa above.

\section{Order Characiformes}

Morphological synapomorphies: same as Characiphysae.

Comments: although characifom monophyly has been elusive for most molecular studies (e.g., [72, 179, 189]), our recent phylogenomic study provides overwhelming support for the monophyly of the order [101]. Nodal support values of suborders are from D Arcila, G Ortí, RP Vari, JW Armbruster, MLJ Stiassny, $\mathrm{K}$ Ko, MH Sabaj, J Lundberg, LJ Revell and R Betancur-R. [101]. 
Suborder Citharinoidei (100\%)

Morphological synapomorphies: see RP Vari [190], SV

Fink and WL Fink [175], SV Fink and WL Fink [176],

RP Vari [188].

Citharinidae

Distichodontidae

Suborder Characoidei (100\%)

Morphological synapomorphies: see SV Fink and WL

Fink [175], SV Fink and WL Fink [176], RP Vari [188].

Acestrorhynchidae

Alestidae

Anostomidae

Chalceidae

Characidae

Chilodontidae

Crenuchidae

Ctenoluciidae

Curimatidae

Cynodontidae

Erythrinidae

Gasteropelecidae

Hemiodontidae

Hepsetidae

Iguanodectidae

Lebiasinidae

Parodontidae

Prochilodontidae

Serrasalmidae

Triportheidae

Not examined: Bryconidae.

Superorder Siluriphysae (= Siluriphysi) (100\%)

Morphological synapomorphies: see SV Fink and WL

Fink [175], SV Fink and WL Fink [176].

Order Gymnotiformes (100\%)

Morphological synapomorphies: see SV Fink and WL Fink [175], SV Fink and WL Fink [176], VA Tagliacollo, MJ Bernt, JM Craig, C Oliveira and JS Albert [191].

Comments: VA Tagliacollo, MJ Bernt, JM Craig, C Oliveira and JS Albert [191] proposed a revised classification for Gymnotiformes based on the most comprehensive phylogenetic analyses of the order to date, using both multi-locus sequence data and morphological evidence. They obtained two major clades within Sternopygoidei, which they named Rhamphichthyoidea (Rhamphichthyidae + Hypopomidae) and Sinusoidea (Sternopygidae + Apteronotidae). Although ranks for these clades are not explicit in their classification scheme, the endings suggest that these are superfamilies. According to the ICZN (article 61.2.2) "when a nominal taxon in the family group... is raised or lowered in rank, or its name is used at more than one rank simultaneously, the name-bearing type remains the same [Arts. 36.2, 43.1, 46.2]." In other words, the proper superfamily name for the "Sinusoidea" clade should be
Sternopygoidea (suborder Sternopygoidei), to reflect a name-bearing type. Aside from these nomenclatural points, a phylogenomic-based gymnotiform clade (with a limited taxonomic sampling) does not support the monophyly of "Sinusoidea" [101]. Nodal support values of suborders are from D Arcila, G Ortí, RP Vari, JW Armbruster, MLJ Stiassny, K Ko, MH Sabaj, J Lundberg, LJ Revell and R Betancur-R. [101].

Suborder Gymnotoidei (100\%)

Morphological synapomorphies: see VA Tagliacollo, MJ

Bernt, JM Craig, C Oliveira and JS Albert [191].

Gymnotidae

Suborder Sternopygoidei (not monophyletic here but see [191])

Morphological synapomorphies: see VA Tagliacollo, MJ

Bernt, JM Craig, C Oliveira and JS Albert [191].

Apteronotidae

Hypopomidae

Rhamphichthyidae

Sternopygidae

Order Siluriformes (100\%)

Morphological synapomorphies: see SV Fink and WL Fink [175], SV Fink and WL Fink [176], G Arratia [192], T Mo [193], G Arratia [194], MCC de Pinna [195], MCC de Pinna [196], R Diogo [197]; see also JP Sullivan, JG Lundberg and M Hardman [198].

Comments: recognition of catfish families follows JP Sullivan, JG Lundberg and M Hardman [198] and JG Lundberg, JP Sullivan, R Rodiles-Hernández and DA Hendrickson [77], except for Ailiidae, Auchenoglanididae and Ritidae that are herein recognized following JS Nelson, T Grande and MVH Wilson [42], and Kryptoglanidae that follows R Britz, F Kakkassery and $R$ Raghavan [199]. The subordinal classification is based on JP Sullivan, JG Lundberg and M Hardman [198]. Nodal support values of suborders are from D Arcila, G Ortí, RP Vari, JW Armbruster, MLJ Stiassny, K Ko, MH Sabaj, J Lundberg, LJ Revell and R Betancur-R. [101].

Suborder Loricarioidei (75\%)

Morphological synapomorphies: see R Diogo [197].

Astroblepidae

Callichthyidae

Loricariidae

Nematogenyidae

Trichomycteridae

Not examined: Scoloplacidae.

Suborder Diplomystoidei

Morphological synapomorphies: see G Arratia [192], G Arratia [194], MCC de Pinna [195], MCC de Pinna [196], G Arratia and C Quezada-Romegialli [200].

Diplomystidae

Suborder Siluroidei (100\%)

Morphological synapomorphies: see R Diogo [197]. 
Comment: Bagridae includes taxa formerly in Olyridae (following JP Sullivan, JG Lundberg and M Hardman [198]).

Ailiidae

Aspredinidae

Auchenipteridae

Bagridae

Cetopsidae

Clariidae

Claroteidae

Doradidae

Heptapteridae

Ictaluridae

Mochokidae

Pangasiidae

Pimelodidae

Plotosidae

Pseudopimelodidae

Siluridae

Sisoridae

Not examined: Akysidae, Amblycipitidae, Amphiliidae,

Anchariidae, Ariidae, Auchenoglanididae,

Austroglanididae, Chacidae, Cranoglanididae, Erethistidae,

Heteropneustidae, Horabagridae, Kryptoglanidae,

Lacantuniidae, Malapteruridae, Ritidae, and Schilbeidae.

Cohort Euteleosteomorpha (= Euteleostei sensu GD Johnson and C Patterson [49]) (100\%).

Morphological synapomorphies: see GD Johnson and C Patterson [49].

Comments: while relationships among major euteleost lineages are contentious (e.g., Protacanthopterygii; see below), many unexpected clades classified here are consistently obtained by other molecular studies. For instance, alepocephalids have affinities within Otomorpha, instead of Argentiformes as proposed by GD Johnson and C Patterson [49] (e.g., [173]; see also comments under Alepocephali above); Lepidogalaxias (order Lepidogalaxiiformes) lies at the base of the euteleost tree (e.g., [201]), rendering Galaxiidae sensu lato non-monophyletic; Osmeriformes (considered a suborder of Salmoniformes by EO Wiley and GD Johnson [57]) and Stomiatiformes are sister orders (see also [76]), placed here in the subcohort Stomiati.

\section{Subcohort Lepidogalaxii}

Morphological synapomorphies: see DE Rosen [202].

\section{Order Lepidogalaxiiformes}

Morphological synapomorphies: same as Lepidogalaxii. Lepidogalaxiidae

Subcohort Protacanthopterygii sedis mutabilis (100\%)

Comments: Circumscription of Protacanthopterygii is controversial (hence sedis mutabilis). JS Nelson, T Grande and MVH Wilson [42] restricted Protacanthopterygii to the clade including Salmoniformes and
Esociformes. They also placed the orders Galaxiiformes and Argentiniformes, along with Stomiatiformes and Osmeriformes, in a new taxon they named Osmeromorpha. Circumscription of Osmeromorpha follows the results of the molecular phylogeny of CP Burridge, RM McDowall, D Craw, MVH Wilson and JM Waters [203]. Note that Burridge et al.'s study was designed to address intrafamilial galaxiid relationships. Their selection of non-galaxiid outgroups was only for time-calibration purposes; they did not intend to assess supraordinal relationships among early euteleosts. In addition to Osmeromorpha, JS Nelson, T Grande and MVH Wilson [42] classified a purported clade including most euteleosts, except for Lepidogalaxiiformes, Salmoniformes and Esociformes, in an unranked taxon named Zoroteleostei by MVH Wilson and RG Williams [204]. Circumscriptions of Osmeromorpha and Zoroteleostei sensu JS Nelson, T Grande and MVH Wilson [42] are incongruent with all recent higher-level phylogenetic analyses of fishes (i.e., [8-10, 27]).

Order Argentiniformes (47\%)

Morphological synapomorphies: see GD Johnson and C Patterson [49].

Argentinidae

Bathylagidae

Microstomatidae

Opisthoproctidae

Order Galaxiiformes (94\%)

Morphological synapomorphies: lacking.

Galaxiidae

Order Salmoniformes (62\%)

Morphological synapomorphies: see CJ Sanford [205], GD Johnson and C Patterson [49], [206].

Salmonidae

Order Esociformes (100\%)

Morphological synapomorphies: see GD Johnson and C Patterson [49].

Esocidae

Umbridae

Subcohort Stomiati (100\%)

Morphological synapomorphies: lacking

Comments: see comments under Protacanthopterygii above.

Order Stomiatiformes sensu DE Rosen [43] (= Stomiiformes sensu WL Fink and SH Weitzman [207]) (100\%)

Morphological synapomorphies: see AS Harold and SH Weitzman [208], AS Harold [209].

Comments: suborders in Stomiatiformes are now recognized following JS Nelson, T Grande and MVH Wilson [42], except that their Phosichthyoidei is named Stomiatoidei herein (based on Stomiidae).

Suborder Gonostomatoidei (54\%)

Morphological synapomorphies: see AS Harold [209]. 
Comment: Diplophidae is no longer recognized as a separate family; it is listed as subfamily of Gonostomatidae in R Van Der Laan, WN Eschmeyer and R Fricke [62] and JS Nelson, T Grande and MVH Wilson [42]. Diplophos is sister to all other gonostomatids in Fig. 2.

Gonostomatidae

Suborder Stomiatoidei (= Phosichthyoidei) (61\%)

Morphological synapomorphies: lacking.

Phosichthyidae (not monophyletic in Fig. 2).

Sternoptychidae

Stomiidae

\section{Order Osmeriformes $(100 \%)$}

Morphological synapomorphies: Formal diagnosis of the present order is not established on synapomorphies. This concept conflicts with the morphological hypothesis of GD Johnson and C Patterson [49] who grouped retropinnids with galaxiids and lepidogalaxiids.

Comments: EO Wiley and GD Johnson [57], citing GD Johnson and C Patterson [49], placed Galaxiidae as sister to retropinnids within the suborder Osmeroidei (order Salmoniformes sensu EO Wiley and GD Johnson [57]). Suborders in Osmeriformes are now classified following JS Nelson, T Grande and $\mathrm{MVH}$ Wilson [42].

Suborder Osmeroidei (100\%)

Morphological synapomorphies: GD Johnson and C Patterson [49].

Osmeridae

Plecoglossidae

Salangidae

Suborder Retropinnoidei (100\%)

Morphological synapomorphies: GD Johnson and C Patterson [49].

Comment: Retropinnidae includes the former Prototroctidae, following JS Nelson, $\mathrm{T}$ Grande and $\mathrm{MVH}$ Wilson [42].

Retropinnidae

Subcohort Neoteleostei (100\%)

Morphological synapomorphies: see DE Rosen [43], GD Johnson [210], EO Wiley and GD Johnson [57]. Note that previous classifications (e.g., [57]) included Stomiiformes in Neoteleostei.

Infracohort Ateleopodia (= Ateleopodomorpha) (98\%). Morphological synapomorphies: see DE Rosen [43], JE Olney, DG Johnson and CC Baldwin [211].

\section{Order Ateleopodiformes}

Morphological synapomorphies: same as Ateleopodia. Ateleopodidae

Infracohort Eurypterygia (= Eurypterygii) (96\%)

Morphological synapomorphies: see GV Lauder and KF Liem [36], GD Johnson [210], MLJ Stiassny [212], VG Springer and DG Johnson [213].

Section Cyclosquamata (= Aulopa) (100\%)
Morphological synapomorphies: see C Baldwin and GD Johnson [214], TP Satoh and T Nakabo [215], MP Davis [216].

Comment: We now recognize Cyclosquamata sensu Rosen following other recent classifications (e.g., [42, 216]; = Aulopa in EO Wiley and GD Johnson [57] and in previous versions of this classification).

Order Aulopiformes (100\%)

Morphological synapomorphies: same as Cyclosquamata.

Comment: although not monophyletic herein, the monophyly of aulopiform suborders is supported by MP Davis [216]. Aulopiform families listed follow MP Davis [216] and other recent sources (see below).

Suborder Aulopoidei (not monophyletic in Fig. 2) (= Synodontoidei sensu C Baldwin and GD Johnson [214] and EO Wiley and GD Johnson [57]).

Morphological synapomorphies: see C Baldwin and GD Johnson [214], MP Davis [216].

Aulopidae

Pseudotrichonotidae

Synodontidae (not monophyletic in Fig. 2).

Suborder Paraulopoidei

Morphological synapomorphies: see MP Davis [216].

Paraulopidae

Suborder Alepisauroidei (not monophyletic in Fig. 2) Morphological synapomorphies: see MP Davis [216].

Comments: Alepisauridae includes taxa previously listed in Omosudidae and Anotopteridae, following MP Davis [216]. Lestidiidae is now recognized following MJ Ghedotti, RW Barton, AM Simons and MP Davis [217] and JS Nelson, $\mathrm{T}$ Grande and $\mathrm{MVH}$ Wilson [42].

Alepisauridae

Bathysauridae

Chlorophthalmidae (not monophyletic in Fig. 2)

Evermannellidae

Giganturidae

Ipnopidae (not monophyletic in Fig. 2)

Lestidiidae

Notosudidae

Paralepididae (not monophyletic in Fig. 2)

Scopelarchidae (not monophyletic in Fig. 2)

Sudidae (following [216])

Not examined: Bathysauroididae, Bathysauropsidae sensu MP Davis [216].

Section Ctenosquamata sensu DE Rosen [43] (100\%)

Morphological synapomorphies: see GD Johnson [210], MLJ Stiassny [212].

Subsection Myctophata (= Scopelomorpha) (100\%)

Morphological synapomorphies: see MLJ Stiassny [212], VG Springer and DG Johnson [213].

Order Myctophiformes

Morphological synapomorphies: same as Myctophata. 
Myctophidae

Neoscopelidae

Subsection Acanthomorphata (= Acanthomorpha) (96\%)

Morphological synapomorphies: see MLJ Stiassny [218], GD Johnson and C Patterson [51], D Davesne, C Gallut, V Barriel, P Janvier, G Lecointre and O Otero [24].

Division Lampripterygii (= Lampridacea in previous versions; = Lamprimorpha in [42]) (82\%).

Morphological synapomorphies: see JE Olney, DG Johnson and CC Baldwin [211] (but including Stylephorus, now in Stylephoriformes; see below), D Davesne, M Friedman, V Barriel, G Lecointre, P Janvier, C Gallut and O Otero [219].

Comments: Endings for the rank "division" have been changed to "-pterygii" (see comments under Acanthopterygii below).

Order Lampriformes (= Lampridiformes in previous versions, = Allotriognathi).

Morphological synapomorphies: same as Lampripterygii.

Lampridae (= Lamprididae in previous versions).

Lophotidae

Regalecidae

Trachipteridae

Not examined: Radiicephalidae, Veliferidae.

Division Paracanthopterygii sensu M Miya, T Satoh and M Nishida [69], T Grande, WC Borden and WL Smith [220] (but excluding Polymixiidae; = Paracanthomorphacea in previous versions) (100\%).

Morphological synapomorphies: see T Grande, WC Borden and WL Smith [220], but restricted to our concept of the clade (without Polymixia).

Comments: endings for the rank Division have been changed to "-pterygii" (see comments under Acanthopterygii below). Placement of Polymixiidae inside [69, 106, 220] or outside $[8,10,11,27]$ Paracanthopterygii is contentious. A restricted circumscription of Paracanthopterygii, including only the orders Percopsiformes, Zeiformes, Stylephoriformes, and Gadiformes is largely robust to phylogenetic uncertainty.

Series Percopsaria (100\%)

Morphological synapomorphies: see VG Springer and DG Johnson [213], T Grande, WC Borden and WL Smith [220], D Davesne, C Gallut, V Barriel, P Janvier, G Lecointre and O Otero [24].

\section{Order Percopsiformes}

Morphological synapomorphies: same as Percopsaria.

Amblyopsidae

Aphredoderidae

Percopsidae

Series Zeiogadaria (= Zeiogadiformes sensu B Li, A Dettai, C Cruaud, A Couloux, M Desoutter-Meniger and G Lecointre [80]) (100\%)

Morphological synapomorphies: see D Davesne, C Gallut, V Barriel, P Janvier, G Lecointre and O Otero [24].
Subseries Zeiariae (100\%)

Morphological synapomorphies: see GD Johnson and C Patterson [51], JC Tyler, B O'Toole and R Winterbottom [221], D Davesne, C Gallut, V Barriel, P Janvier, G Lecointre and O Otero [24].

\section{Order Zeiformes}

Morphological synapomorphies: same as Zeiariae.

Comment: Zeiform suborders are now classified following JC Tyler, B O'Toole and R Winterbottom [221] and JS Nelson, T Grande and MVH Wilson [42].

\section{Suborder Cyttoidei}

Morphological synapomorphies: see JC Tyler, B O'Toole and R Winterbottom [221].

Not examined: Cyttidae.

\section{Suborder Zeiodei}

Morphological synapomorphies: see JC Tyler, B O'Toole and R Winterbottom [221].

Parazenidae

Zeidae

Zeniontidae (= Zenionidae)

Not examined: Grammicolepididae, Oreosomatidae.

Subseries Gadariae (100\%)

Morphological synapomorphies: lacking; note that morphology unites Stylephoriformes with Zeiformes to the exclusion of Gadiformes [24].

Order Stylephoriformes sensu M Miya, NI Holcroft, TP Satoh, M Yamaguchi, M Nishida and EO Wiley [70].

Morphological synapomorphies: see JE Olney, DG Johnson and CC Baldwin [211].

Comment: Removal of Stylephoridae from Lampriformes is well supported by molecular evidence $[8,10,70]$.

Stylephoridae

Order Gadiformes (100\%)

Morphological synapomorphies: see H Endo [222].

Comments: the classification of suborders and families in Gadiformes is controversial (see discussion in A Roa-Varon and G Orti ([223]: Fig. 6) and recent results by $M$ Malmstrøm, $M$ Matschiner, OK Tørresen, B Star, LG Snipen, TF Hansen, HT Baalsrud, AJ Nederbragt, R Hanel, W Salzburger, et al. [106]). Until further evidence for resolution of relationships among families becomes available, we refrain from classifying suborders and list all families alphabetically. The family Lotidae is no longer recognized here because it is not monophyletic (see also [106]); the three genera (Brosme, Lota, and Molva) formerly in Lotidae are now included in Gadidae (see also JS Nelson, T Grande and MVH Wilson [42]). The families Bathygadidae, Macruronidae, Ranicipitidae, and Trachyrincidae (not validated in previous versions) are now recognized following JS Nelson, T Grande and MVH Wilson [42].

Bathygadidae

Gadidae 
Gaidropsaridae

Macrouridae

Macruronidae

Merlucciidae

Moridae

Muraenolepididae

Phycidae

Steindachneriidae

Not examined: Bregmacerotidae, Euclichthyidae,

Melanonidae, Ranicipitidae, Trachyrincidae.

Division Polymixiipterygii (100\%)

Morphological synapomorphies: see MLJ Stiassny [218], D Davesne, C Gallut, V Barriel, P Janvier, G Lecointre and O Otero [24].

Comments: endings for the rank Division have been changed to "-pterygii" (see comments under Acanthopterygii below). We place Polymixiidae in its own division (as opposed to Paracanthopterygii as in previous studies $[69,106,220])$ to recognize its rogue placement among early acanthomorph lineages. See also comments above under Paracanthopterygii.

Order Polymixiiformes

Morphological synapomorphies: same as Polymixiipterygii.

Polymixiidae

Division Acanthopterygii (= Euacanthomorphacea in previous versions) (95\%)

Morphological synapomorphies: see MLJ Stiassny and JA Moore [52], GD Johnson and C Patterson [51], EO Wiley and GD Johnson [57] (but their circumscription of the group includes Zeiformes).

Comment: previous versions of this classification named this clade Euacanthomorphacea, a taxon recognized by GD Johnson and C Patterson [51] to include polymixiids, percopsids and crown acanthomorphs. Because polymixiids and percopsids are not members of this group, it seems reasonable to instead adopt Acanthopterygii, recognizing its extensive use in ichthyology. Note that Acanthopterygii was listed but not classified by EO Wiley and GD Johnson [57]. This change follows TJ Near, A Dornburg, RI Eytan, BP Keck, WL Smith, KL Kuhn, JA Moore, SA Price, FT Burbrink, M Friedman, et al. [11] and JS Nelson, T Grande and MVH Wilson [42]. For consistency, we also changed all Division suffixes to "-pterygii."

\section{Subdivision Berycimorphaceae (100\%)}

Morphological synapomorphies: lacking for the entire group. A subgroup comprised of berycoids, trachichthyiforms and holocentriforms, but excluding stephanoberycoids has been recognized by presence of the Jakubowski's organ and the absence of pharyngobranchial 4 [51]. This subgroup plus the zeiforms was also united by GD Johnson and C Patterson [51] with Percomorphaceae based on three hypothesized synapomorphies. These authors also hypothesized a sister-group relationship between
Beryciformes (minus stephanoberycoids) and Percomorphaceae (forming the Euacanthopterygii) based on five other synapomorphies (see [57]). More recently, D Davesne, C Gallut, V Barriel, P Janvier, G Lecointre and O Otero [24] recognized holocentriforms as the sister to Percomorphaceae, as proposed originally by MLJ Stiassny and JA Moore [52]. We conclude that no current diagnosis based on morphological synapomorphies exists for this clade.

Comments: Beryciformes sensu lato (as in previous versions) is now split into Beryciformes sensu stricto (including Berycoidei and Stephanoberycoidei) and Trachichthyiformes sensu JA Moore [53], following JS Nelson, T Grande and MVH Wilson [42].

Order Beryciformes (100\%)

Morphological synapomorphies: lacking for current circumscription; see JA Moore [53] and MLJ Stiassny and JA Moore [52].

Comment: beryciform suborders are now classified following JS Nelson, T Grande and MVH Wilson [42].

Suborder Berycoidei (100\%)

Morphological synapomorphies: lacking for current circumscription; see JA Moore [53] and MLJ Stiassny and JA Moore [52].

Berycidae

Melamphaidae

Suborder Stephanoberycoidei (78\%)

Morphological synapomorphies: see GD Johnson and C Patterson [49], JA Moore [53]. Note that GD Johnson and C Patterson [49] did not consider stephanoberycoids closely related to other beryciforms and suggested that JA Moore [53]'s synapomorphies were ambiguous.

Barbourisiidae

Cetomimidae

Rondeletiidae

Stephanoberycidae

Not examined: Gibberichthyidae, Hispidoberycidae.

Order Trachichthyiformes sensu JA Moore [53] (100\%)

Morphological synapomorphies: see JA Moore [53] and

C Baldwin and GD Johnson [224].

Comment: The subordinal classification for Trachichthyiformes proposed by JS Nelson, T Grande and MVH Wilson [42] is incongruent with the phylogeny in Fig. 2 and is therefore not implemented herein.

\section{Anomalopidae}

Anoplogastridae

Diretmidae

Monocentridae

Trachichthyidae (not monophyletic in Fig. 2)

Subdivision Holocentrimorphaceae (100\%)

Morphological synapomorphies: MLJ Stiassny and JA Moore [52] and JA Moore [53] provided morphological evidence supporting a sister-group relationship between holocentrids and percomorphs, validating the placement 
of this family in its own order (but see [225, 226]). See also D Davesne, C Gallut, V Barriel, P Janvier, G Lecointre and O Otero [24].

Order Holocentriformes

Morphological synapomorphies: same as

Holocentrimorphaceae.

Holocentridae

Subdivision Percomorphaceae (= Percomorpha sensu M Miya, H Takeshima, H Endo, N Ishiguro, J Inoue, T Mukai, T Satoh, M Yamaguchi, A Kawaguchi, K Mabuchi, et al. [68], and M Miya, T Satoh and M Nishida [69]).

Morphological synapomorphies: see GD Johnson and C Patterson [49], EO Wiley and GD Johnson [57].

Comments: the diversity of percomorph fishes $(>17,000$ species) is grouped into nine well-supported series (supraordinal groups). See comments in the Introduction.

Series Ophidiaria (100\%)

Morphological synapomorphies: a cranial ophidiiform synapomorphy was recently proposed by G Carnevale and D Johnson [227]. Although monophyly of this group is robust from a molecular perspective, evidence from other anatomical studies is rather weak (e.g., [35, 57, 228, 229]).

\section{Order Ophidiiformes}

Morphological synapomorphies: same as Ophidiaria.

Suborder Ophidioidei (100\%)

Morphological synapomorphies: lacking; see JG Nielsen, Cohen, D. M., Markle, D. F. \& Robins, C. R. [229], EO Wiley and GD Johnson [57].

Ophidiidae (includes the former Carapidae).

Suborder Bythitoidei (100\%)

Morphological synapomorphies: see C Patterson and D Rosen [230] and JG Nielsen, Cohen, D. M., Markle, D. F. \& Robins, C. R. [229].

Comments: Carapidae is now synonymized with Ophidiidae due to phylogenetic nestedness. Recognition of Dinematichthyidae follows PR Møller, SW Knudsen, W Schwarzhans and JG Nielsen [231]; raised from subfamily Dinematichthyinae (formerly Bythitidae). These authors also lumped Aphyonidae with Bythitidae; thus, Aphyonidae is no longer validated. Finally, Parabrotulidae is also now synonymized with Bythitidae based on recent results by MA Campbell, JG Nielsen, T Sado, C Shinzato, M Kanda, TP Satoh and M Miya [232].

Dinematichthyidae

Bythitidae (includes the former Aphyonidae and

Parabrotulidae).

Series Batrachoidaria (100\%)

Morphological synapomorphies: see DW Greenfield, R Winterbottom and BB Collette [233], EO Wiley and GD Johnson [57] (references therein).

Order Batrachoidiformes

Morphological synapomorphies: same as Batrachoidaria. Batrachoididae
Series Pelagiaria (= Stromateoidei sensu B Li, A Dettai, C Cruaud, A Couloux, M Desoutter-Meniger and G Lecointre [80]; = Pelagia sensu M Miya, M Friedman, TP Satoh, $\mathrm{H}$ Takeshima, T Sado, W Iwasaki, Y Yamanoue, M Nakatani, K Mabuchi, JG Inoue, et al. [234]) (99\%).

Morphological synapomorphies: lacking. The diagnosis provided by EO Wiley and GD Johnson [57], based on GD Johnson [235], includes families placed outside this clade in Fig. 2 (e.g., Istiophoridae). The circumscription of Scombriformes presented here is also incongruent with that of BB Collette, T Potthoff, WJ Richards, S Ueyanagi, JL Russo and Y Nishikawa [236] and other studies cited by EO Wiley and GD Johnson [57]. No morphological diagnosis exists for pelagiarians, representing a case of significant incongruence between morphological and molecular data. Despite the disparate morphology among members of Scombriformes, most are offshore fishes that inhabit pelagic environments (hence the clade name).

\section{Order Scombriformes}

Morphological synapomorphies: same as Pelagiaria.

Comment: interfamilial resolution in Scombriformes is tenuous; classification of scombriform families into suborders (e.g., Scombroidei, Stromateoidei, Icosteoidei) or new orders requires further work. Our circumscription of Scombriformes includes taxa placed by JS Nelson, T Grande and MVH Wilson [42] in the orders Scombriformes, Trachiniformes in part, Icosteiformes and Scombrolabraciformes.

Ariommatidae

Arripidae

Bramidae

Caristiidae

Centrolophidae

Chiasmodontidae

Gempylidae (not monophyletic in Fig. 2)

Icosteidae

Nomeidae

Pomatomidae

Scombridae (not monophyletic here, but see [234])

Scombrolabracidae

Stromateidae

Trichiuridae

Not examined: Amarsipidae, Scombropidae,

Tetragonuridae (see $[234,237])$.

Series Syngnatharia $(84 \%)$

Morphological synapomorphies: lacking; no morphological character seems to unite some disparate groups (e.g., mullids) with other members of this clade (e.g., syngnathids).

Comment: Nodal support values of suborders are from SJ Longo, BC Faircloth, A Meyer, MW Westneat, ME Alfaro and PC Wainwright [103]. 
Order Syngnathiformes (see also [103, 238])

Morphological synapomorphies: same as Syngnatharia.

Suborder Syngnathoidei (100\%)

Morphological synapomorphies: EO Wiley and GD Johnson [57] diagnosis included the family Pegasidae, now placed in Dactylopteroidei.

Aulostomidae

Centriscidae (including taxa often placed in

Macroramphosidae)

Fistulariidae

Solenostomidae

Syngnathidae

Suborder Dactylopteroidei (>92\%; see [103])

Morphological synapomorphies: sea moths (pegasids) and flying gurnards (dactylopterids) share the condition of fused nasals in adults [57] - a possible synapomorphy.

Dactylopteridae

Pegasidae

Suborder Callionymoidei (= Callionymiformes sensu JS Nelson, T Grande and MVH Wilson [42]) (100\%)

Morphological synapomorphies: see EO Wiley and GD Johnson [57], citing WA Gosline [239], who grouped callionymoids with Gobiesocoidei in the order Gobiesociformes.

Callionymidae

Not examined: Draconettidae (assumed affinity with

Callionymidae).

Suborder Mulloidei (100\%)

Morphological synapomorphies: see B-J Kim [240].

Mullidae

Series Gobiaria (= Gobiiformes sensu CE Thacker [241], and CE Thacker, TP Satoh, E Katayama, RC Harrington, RI Eytan and TJ Near [242]) (100\%)

Morphological synapomorphies: CE Thacker [241], CE Thacker [241], and CE Thacker, TP Satoh, E Katayama, RC Harrington, RI Eytan and TJ Near [242].

Order Kurtiformes (= Apogonoidei sensu CE Thacker, TP Satoh, E Katayama, RC Harrington, RI Eytan and TJ Near [242]) (100\%)

Morphological synapomorphies: GD Johnson [50] noted that the configuration of dorsal gill-arch elements and sensory papillae may be homologous in Kurtus and apogonids (see also [241]).

Suborder Kurtoidei (100\%)

Morphological synapomorphies: see TM Berra [243].

Kurtidae

Suborder Apogonoidei (100\%)

Morphological synapomorphies: see C Baldwin and GD Johnson [244].

Apogonidae

Order Gobiiformes (100\%) (=Trichonotoidei sensu CE Thacker, TP Satoh, E Katayama, RC Harrington, RI Eytan and TJ Near [242])
Morphological synapomorphies: lacking for current circumscription, but see discussion in CE Thacker [241], and CE Thacker, TP Satoh, E Katayama, RC Harrington, RI Eytan and TJ Near [242].

Comments: The classification of suborders in Gobiiformes is now based on CE Thacker, TP Satoh, E Katayama, RC Harrington, RI Eytan and TJ Near [242], but with modifications. Our delimitation of Kurtiformes is the same as Apogonoidei in CE Thacker, TP Satoh, E Katayama, RC Harrington, RI Eytan and TJ Near [242]. We also place Trichonotus in its own suborder (Trichonotoidei) in Gobiiformes (see comments below); note that Trichonotoidei sensu CE Thacker, TP Satoh, E Katayama, RC Harrington, RI Eytan and TJ Near [242] is equivalent to Gobiiformes here. Finally, Odontobutoidei and Eleotroidei, validated in previous versions of the classification, are now considered synonyms of Gobioidei.

\section{Suborder Trichonotoidei}

Morphological synapomorphies: JS Nelson [245], DG Smith and GD Johnson [246].

Comments: DG Smith and GD Johnson [246] allied Trichonotus with two families we place in the Pempheriformes (Creediidae and Hemerocoetidae) as subfamilies of an expanded Trichonotidae on the basis of specialized configuration of the suspensorium (following JS Nelson [245]). Placement of Trichonotoide here is based on molecular evidence from CE Thacker, TP Satoh, E Katayama, RC Harrington, RI Eytan and TJ Near [242], who identified Trichonotus as the sister lineage of the gobies (rendering Trichonotidae sensu DG Smith and GD Johnson [246] polyphyletic).

Not examined: Trichonotidae.

\section{Suborder Gobioidei (100\%)}

Morphological synapomorphies: see $\mathrm{R}$ Winterbottom [247], GD Johnson and EB Brothers [248]; see also Gobiiformes in EO Wiley and GD Johnson [57].

Comments: recognition of Butidae, Oxudercidae and Milyeringidae follows CE Thacker [241] and CE Thacker, TP Satoh, E Katayama, RC Harrington, RI Eytan and TJ Near [242]. We now recognize Oxudercidae instead of Gobionellidae (Gobionellidae is a junior synonym). The former Microdesmidae, Kraemeriidae, Ptereleotridae, and Schindleriidae are now synonymized with Gobiidae [241, 242]. The former Xenisthmidae is now synonymized with Eleotridae [241]. Note that Schindleriidae was first recognized as a goby by GD Johnson and EB Brothers [248].

Eleotridae

Gobiidae

Odontobutidae

Not examined: Butidae, Milyeringidae, Oxudercidae

(= Gobionellidae), Rhyacichthyidae, Thalasseleotrididae. 
Series Anabantaria (= Anabantiformes sensu B Li, A Dettai, C Cruaud, A Couloux, M Desoutter-Meniger and G Lecointre [80]) (100\%)

Morphological synapomorphies: lacking.

Comments: members of this group are mostly of freshwater origin and their geographic distribution is largely restricted to Africa and South East Asia (although some synbranchid species occur in Mexico and Central and South America). Most species occupy marginal, stagnant waters due to their capacity to tolerate anoxia and to obtain oxygen directly from the air.

\section{Order Synbranchiformes (100\%)}

Morphological synapomorphies: lacking for current circumscription (with Indostomidae); for synapomorphies uniting Mastacembeloidei and Synbranchoidei, see RA Travers [249], GD Johnson and C Patterson [49], R Britz [250], EO Wiley and GD Johnson [57].

Suborder Mastacembeloidei (100\%)

Morphological synapomorphies: see RA Travers [249],

R Britz and M Kottelat [251].

Mastacembelidae

Not examined: Chaudhuriidae.

Suborder Indostomoidei (100\%)

Morphological synapomorphies: $\mathrm{R}$ Britz and GD Johnson [252], but placed phylogenetically with

Gasterosteales.

Indostomidae

\section{Suborder Synbranchoidei}

Morphological synapomorphies: see DE Rosen and PH Greewood [253].

Synbranchidae

Order Anabantiformes sensu R Britz [254] (= Labyrinthici) (100\%)

Morphological synapomorphies: see R Britz [254], R Britz [255].

Comment: Affinities of Channidae with other anabantiform families vary among studies (e.g., $[8,11,92])$. The subordinal scheme presented with three suborders is robust to this ambiguity.

\section{Suborder Anabantoidei (100\%)}

Morphological synapomorphies: see GV Lauder and KF Liem [36], R Britz [255], VG Springer and DG Johnson [213].

Anabantidae

Helostomatidae

Osphronemidae

Suborder Channoidei (100\%)

Morphological synapomorphies: see GV Lauder and KF Liem [36], EO Wiley and GD Johnson [57] and citations therein.

Channidae

Suborder Nandoidei (91\%)
Morphological synapomorphies: RA Collins, R Britz and L Rüber [256].

\section{Badidae}

Nandidae

Pristolepididae

Series Carangaria (= Carangimorpha sensu B Li, A Dettai, C Cruaud, A Couloux, M Desoutter-Meniger and G Lecointre [80]; = Carangimorpharia in previous versions of this classification) (99\%)

Morphological synapomorphies: in looking for possible anatomical synapomorphies uniting flatfishes, billfishes, and carangids, AG Little, SC Lougheed and CD Moyes [257] found that most taxa share a relatively low number of vertebrae, have multiple dorsal pterygiophores inserting before the second neural spine, and lack supraneurals. However, according to M Friedman [258], some of these characters are symplesiomorphies while others are absent in the remaining carangimorph groups. Despite the apparent lack of morphological synapomorphies for carangimorphs there is a strong molecular signal supporting their monophyly (e.g., [8, 11, 27, 80, 92, 100, 259-261]). Inclusion of the billfishes (Istiophoriformes) in this series represents a significant departure from previous work in morphology where most studies placed them within or sister to the scombriforms (among pelagiarians) (see [57]).

Comment: Centropomidae includes the former Latidae, following $\mathrm{PH}$ Greenwood [262] and $\mathrm{C} \mathrm{Li}, \mathrm{R}$ Betancur-R., WL Smith and G Orti [82].

\section{Order-level incertae sedis in Carangaria}

Centropomidae

Lactariidae

Leptobramidae

Menidae

Polynemidae

Sphyraenidae

Toxotidae

Order Istiophoriformes (= superfamily Xiphiicae sensu I Nakamura [263]) (100\%)

Morphological synapomorphies: see I Nakamura [263].

Comment: our tree (Fig. 2) does not support placement of Sphyraenidae in this order, as suggested by JS Nelson, T Grande and MVH Wilson [42].

Istiophoridae

Xiphiidae

Order Carangiformes (not monophyletic in Fig. 2)

Morphological synapomorphies: see GD Johnson [59], WF Smith-Vaniz [264].

Comment: monophyly of Carangiformes is not significantly rejected by the data [259].

Carangidae

Coryphaenidae

Echeneidae 
Nematistiidae

Rachycentridae

Order Pleuronectiformes (21\%)

Morphological synapomorphies: see F Chapleau [265],

TA Munroe [266].

Comment: although contentious (e.g., [261]), the monophyly of Pleuronectiformes is resolved by several molecular studies [92, 100, 259, 260].

Suborder Psettodoidei (100\%)

Morphological synapomorphies: see F Chapleau [265], TA Munroe [266].

Psettodidae

Suborder Pleuronectoidei (99\%)

Morphological synapomorphies: see F Chapleau [265],

TA Munroe [266].

Comment: Paralichthyidae is monophyletic if the Cyclopsetta group is included in its own family [259]. Formal description of a new family for Cyclopsetta is needed in compliance with the ICZN (hence "Cyclopsettidae"). Poecilopsettidae and Paralichthodidae are validated following previous work [265, 266]. Rhombosoleidae includes taxa formerly listed in Achiropsettidae [259, 265, 266].

Achiridae

Bothidae

Citharidae

Cynoglossidae

"Cyclopsettidae" (see comments)

Paralichthyidae

Pleuronectidae

Poecilopsettidae

Rhombosoleidae

Samaridae

Scophthalmidae

Soleidae

Not examined: Paralichthodidae.

Series Ovalentaria sensu Smith and Near in [267] (= Stiassnyiformes sensu B Li, A Dettai, C Cruaud, A Couloux, M Desoutter-Meniger and G Lecointre [80]) (97\%).

Morphological synapomorphies: lacking, but see diagnosis by Smith and Near in [267].

Order-level incertae sedis in Ovalentaria

Comment: Congrogadidae is validated following CM

Godkin and R Winterbottom [268] (formerly a subfamily of Pseudochromidae).

Ambassidae (= Chandidae)

Congrogadidae

Embiotocidae

Grammatidae (= Grammidae; not monophyletic in Fig.

2, but see [269])

Opistognathidae

Plesiopidae

Polycentridae

Pomacentridae

Pseudochromidae
Superorder Cichlomorphae (94\%)

Morphological synapomorphies: lacking; but see PC Wainwright, WL Smith, SA Price, KL Tang, JS Sparks, LA Ferry, KL Kuhn, RI Eytan and TJ Near [267].

\section{Order Cichliformes}

Morphological synapomorphies: same as Cichlomorphae.

Comment: the circumscription of Cichliformes is expanded herein to include Pholidichthyidae (formerly Pholidichthyiformes [42]).

Cichlidae

Pholidichthyidae

Superoder Atherinomorphae (= Atherinomorpha sensu PH Greenwood, DE Rosen, SH Weitzman and GS Myers [6]) (100\%)

Morphological synapomorphies: LR Parenti [270], VG Springer and TM Orrell [271], LR Parenti [272].

Order Atheriniformes (100\%)

Morphological synapomorphies: see LR Parenti [270], BS Dyer and B Chernoff [273], LR Parenti [272].

Suborder Atherinoidei (100\%)

Morphological synapomorphies: see BS Dyer and B Chernoff [273].

Comment: classification of suborders and families in Atheriniformes follows D Campanella, LC Hughes, PJ Unmack, DD Bloom, KR Piller and G Orti [274]; Notocheiridae is no longer recognized (subfamily of Atherinopsidae). These authors did not include Cairnsichthys in Melanotaeniidae, and recommend that it should be recognized as an independent lineage (potential new family).

Atherinidae

Bedotiidae

Isonidae

Melanotaeniidae

Phallostethidae

Pseudomugilidae

Telmatherinidae

Not examined: Atherionidae, Dentatherinidae.

\section{Suborder Atherinopsoidei (100\%)}

Morphological synapomorphies: see BS Dyer and B Chernoff [273].

Comment: Atherinopsidae includes the subfamilies Atherinopsinae, Notocheirinae and Menidiinae. The circumscription of Atherinopsidae sensu JS Nelson, T Grande and MVH Wilson [42] includes only Menidiinae and Atherinopsinae, which renders Atherinopsidae nonmonophyletic (Notocheirinae is nested within; see [274]).

Atherinopsidae

Order Beloniformes (79\%)

Morphological synapomorphies: see DE Rosen and LR Parenti [275], LR Parenti [272], LR Parenti [276].

Suborder Adrianichthyoidei

Morphological synapomorphies: see LR Parenti [276]. 
Adrianichthyidae

Suborder Belonoidei (100\%) (= Exocoetoidei sensu EO Wiley and GD Johnson [57], JS Nelson, T Grande and MVH Wilson [42]).

Morphological synapomorphies: see DE Rosen and LR Parenti [275], LR Parenti [277].

Comment: Belonidae includes the former Scomberesocidae [278, 279].

Belonidae

Exocoetidae

Hemiramphidae (not monophyletic in Fig. 2)

Zenarchopteridae (not monophyletic here, but see

[279])

Order Cyprinodontiformes (100\%)

Morphological synapomorphies: see DE Rosen and LR Parenti [275], LR Parenti [277].

Suborder Aplocheiloidei

Morphological synapomorphies: see LR Parenti [277], WJEM Costa [280].

Comment: according to $\mathrm{R}$ Van Der Laan, WN Eschmeyer and R Fricke [62] the name Rivulidae Myers 1925 is preoccupied by Rivulini Grote 1895 in Lepidoptera (hence "Rivulidae").

Aplocheilidae

Not examined: Nothobranchiidae, "Rivulidae"

(see comments).

Suborder Cyprinodontoidei (100\%)

Morphological synapomorphies: see LR Parenti [277], WJEM Costa [281].

Comments: Cyprinodontidae and Poeciliidae are monophyletic here, with reduced taxonomic sampling, but not in two other recent studies that included a much broader coverage [282, 283]. M Pohl, FC Milvertz, A Meyer and M Vences [283] identified a rogue placement for Pantanodon among cyprinodontiforms. The topology most often obtained by these authors included Pantanodon as sister to all cyprinodontoids. Formal description of a new family for Pantanodon is needed in compliance with the ICZN. The family Valenciidae is herein circumscribed to include the genus Aphanius (formerly in Cyprinodontidae), forming an Eurasian clade (following [283]). This revised circumscription renders Cyprinodontidae monophyletic.

Cyprinodontidae

Fundulidae

Poeciliidae

Not examined: Anablepidae, Goodeidae, Profundulidae, Valenciidae (includes Aphanius; see comments). Possibly included: "Pantanodontidae" (see comments).

Superorder Mugilomorphae (100\%)

Morphological synapomorphies: see MLJ Stiassny [284], GD Johnson [50], GD Johnson and C Patterson [51].

\section{Order Mugiliformes}

Morphological synapomorphies: same as Mugilomorphae. Mugilidae

Superorder Blenniimorphae (90\%)

Morphological synapomorphies: see H-C Lin and PA Hastings [285] (unnamed clade including gobiesocids and blennioids), VG Springer and TM Orrell [271].

Comment: see also PC Wainwright, WL Smith, SA Price, KL Tang, JS Sparks, LA Ferry, KL Kuhn, RI Eytan and TJ Near [267] for additional molecular evidence supporting the reciprocal monophyly of gobiesocoids and blennioids.

Order Gobiesociformes (100\%) (= Gobiesocoidei in EO Wiley and GD Johnson [57])

Morphological synapomorphies: see WA Gosline [239], LR Parenti and J Song [286], EO Wiley and GD Johnson [57].

Comment: the order Gobiesociformes is now recognized following EO Wiley and GD Johnson [57] (but excluding Callionymoidei) and JS Nelson, T Grande and MVH Wilson [42].

Gobiesocidae

Order Blenniiformes (39\%) (= Blennioidei in V Springer [287])

Morphological synapomorphies: see V Springer [287], GD Johnson [50], RD Mooi and AC Gill [288], VG Springer and TM Orrell [271], EO Wiley and GD Johnson [57].

Comments: Circumscription of Blenniiformes follows $\mathrm{H}-\mathrm{C}$ Lin and PA Hastings [285], based on V Springer [287] (Blennioidei). Our new tree (Fig. 2) resolves the blennioids as monophyletic, a result not obtained in our previous large-scale studies. According to $\mathrm{H}-\mathrm{C}$ Lin and PA Hastings [285], Chaenopsidae is monophyletic if Stathmonotus is included in Labrisomidae.

Blenniidae

Chaenopsidae (not monophyletic in Fig. 2)

Clinidae

Dactyloscopidae

Labrisomidae (not monophyletic in Fig. 2, but see [285])

Tripterygiidae

Series Eupercaria (= Percomorpharia in previous versions of this classification) (83\%)

Morphological synapomorphies: lacking.

Comments: with more than 6000 species arranged in 161 families and at least 17 orders (Fig. 1), Eupercaria is by far the largest series of percomorphs. Some of the most diverse orders (e.g., Perciformes, Labriformes, Lophiiformes, and Tetraodontiformes) and families (e.g., Labridae, Serranidae, and Scorpaenidae) of fishes are included in this group. Previous molecular studies obtained monophyletic groups with a combination of taxa here assigned to Eupercaria, but including far more limited sampling (e.g, [11, 58, 68, 69, 289]). Although most family-level and ordinal groups within this series receive 
high nodal support, interrelationships among them are largely unresolved - Eupercaria constitutes the "new bush at the top" [8]. The largest group within Eupercaria is the order Perciformes, as currently circumscribed.

Order-level incertae sedis in Eupercaria.

Comment: although we lack phylogenetic evidence, the family Parascorpididae, traditionally classified in "Perciformes", is provisionally listed here; it is not placed in Perciformes, as currently circumscribed, given the long history of phylogenetic indistinctiveness between Percoidei, Perciformes, and Percomorpha [50, $51,58]$. While not examined, Dinolestidae and Dinopercidae are included here based on previous molecular work [58].

Callanthiidae

Centrogenyidae

Emmelichthyidae

Malacanthidae

Monodactylidae

Moronidae

Pomacanthidae

Scatophagidae

Sciaenidae

Siganidae

Sillaginidae

Not examined: Dinolestidae, Dinopercidae,

Parascorpididae.

Order Gerreiformes (100\%)

Morphological synapomorphies: lacking.

Comment: validation of Gerreiformes (Bleeker name; resurrected herein) reflects the consistent placement of Gerreidae as sister to all other eupercarians.

Gerreidae

Order Uranoscopiformes (= Paratrachinoidei sensu B Li, A Dettai, C Cruaud, A Couloux, M DesoutterMeniger and G Lecointre [80]) (98\%).

Morphological synapomorphies: lacking, but see $\mathrm{H}$ Imamura and K Odani [290] for a review of hypotheses of relationships of the five families in this order to other members of the former suborder Trachinoidei. See also comments in EO Wiley and GD Johnson [57].

Ammodytidae

Cheimarrichthyidae (= Cheimarrhichthyidae)

Pinguipedidae

Uranoscopidae

Order Labriformes (100\%)

Morphological synapomorphies: see M Stiassny and J Jensen [291] and GD Johnson [50].

Labridae (includes taxa previoulsy listed in Scaridae and Odacidae; see also [267]).

Order Ephippiformes (100\%)

Morphological synapomorphies: lacking; however, $\mathrm{PH}$ Greenwood, DE Rosen, SH Weitzman and GS Myers [6] hypothesized a close affinity between Drepane and ephippids, and GD Johnson [50] cites an unpublished dissertation by Blum that provides additional morphological support.

Comments: JS Nelson, T Grande and MVH Wilson [42] named this clade Moroniformes, including Moronidae in addition to Drepaneidae and Ephippidae. Our results do not support the placement of Moronidae in this order.

Drepaneidae

Ephippidae

Order Chaetodontiformes (66\%)

Morphological synapomorphies: lacking.

Comment: this clade has been consistently obtained by previous studies with higher nodal support than that reported here.

Chaetodontidae

Leiognathidae

Order Acanthuriformes, restricted circumscription (see also [292]) (100\%)

Morphological synapomorphies: see JC Tyler, GD Johnson, I Nakamura and BB Collette [293].

Comments: JS Nelson, T Grande and MVH Wilson [42] included Emmelichthyidae and Sciaenidae in this order, in addition to Acanthuridae, Luvaridae and Zanclidae. Our results do not support the placement of Emmelichthyidae and Sciaenidae in Acanthuriformes.

Acanthuridae

Luvaridae

Zanclidae

Order Lutjaniformes, new circumscription (59\%) Morphological synapomorphies: lacking.

Comment: the order Lutjaniformes (Bleeker name) is herein resurrected for the clade including lutjanids and haemulids. Although nodal support is low, this clade is often obtained in various large-scale studies.

Haemulidae

Lutjanidae (includes the former Caesionidae; e.g., [50, 294])

Order Lobotiformes (100\%)

Morphological synapomorphies: lacking, but JM Leis and BM Carson-Ewart [295] suggested that Lobotes, Datnioides, and Hapalogenys share remarkable similarities in larval morphology. See discussion in MD Sanciangco, KE Carpenter and R Betancur-R. [92].

Hapalogenyidae (= Hapalogeniidae)

Datnioididae

Lobotidae

Order Spariformes sensu M Akazaki [296] and GD Johnson [297] (87\%)

Morphological synapomorphies: see M Akazaki [296], GD Johnson [50] and GD Johnson [297].

Comments: the family Centracanthidae is no longer recognized as valid; synonym of Sparidae following $\mathrm{F}$ Santini, G Carnevale and L Sorenson [298] and MD Sanciangco, KE Carpenter and R Betancur-R. [92]. JS 
Nelson, T Grande and MVH Wilson [42] also included in this order the families Callanthiidae, Lobotidae (including Datnioididae) and Sillaginidae. Our results do not support the placement of these three or four families in Spariformes.

Lethrinidae

Nemipteridae

Sparidae (includes the former Centracanthidae)

Order Priacanthiformes, new circumscription (98\%)

Morphological synapomorphies: lacking, but implied by unspecified larval similarities (discussed by JM Leis and BM Carson-Ewart [295]).

Comments: a sister-group relationship between cepolids and priacanthids is strongly supported by other molecular studies (see also [295]).

Priacanthidae

Cepolidae

Order Caproiformes (37\%)

Morphological synapomorphies: lacking, but see F Santini and G Lecointre [299].

Comment: this order is herein recognized following JS

Nelson, T Grande and MVH Wilson [42].

Caproidae

Order Lophiiformes (100\%)

Morphological synapomorphies: see TW Pietsch [300], TW Pietsch [301].

Comments: this order is the sister group of Tetraodontiformes (45\% bootstrap). This relationship is also supported by anatomical evidence [302], larval characters [303], and previous molecular studies $[68,304]$.

Suborder Lophioidei (100\%)

Morphological synapomorphies: see TW Pietsch [300]. Lophiidae

Suborder Antennarioidei (100\%)

Morphological synapomorphies: see TW Pietsch [300].

Antennariidae

Not examined: Brachionichthyidae, Lophichthyidae, Tetrabrachiidae.

Suborder Chaunacoidei (100\%)

Morphological synapomorphies: the suborder is unquestionably monophyletic, but a list of synapomorphies is lacking [57]; for a morphological diagnosis see TW Pietsch and DB Grobecker [305].

Chaunacidae

Suborder Ogcocephaloidei (100\%)

Morphological synapomorphies: the suborder is unquestionably monophyletic, but a list of synapomorphies is lacking [57]; for a morphological diagnosis see TW Pietsch and DB Grobecker [305].

Ogcocephalidae

Suborder Ceratioidei (100\%)

Morphological synapomorphies: T Pietsch and J Orr [306].

Ceratiidae
Gigantactinidae

Himantolophidae

Melanocetidae

Oneirodidae

Not examined: Caulophrynidae, Centrophrynidae,

Diceratiidae, Linophrynidae, Neoceratiidae,

Thaumatichthyidae.

\section{Order Tetraodontiformes (100\%)}

Morphological synapomorphies: several studies by J. Tyler and colleagues (e.g., [307-310]). Morphological synapomorphies for suborders are implied in several recent phylogenetic analyses of fossils and extant taxa (e.g., [23, 310, 311]).

Comments: Although interrelationships of major tetraodontiform lineages is controversial, several clades are congruent across studies. The subordinal classification proposed here differs from that by $\mathrm{F}$ Santini and JC Tyler [310], with many more suborders now recognized. Our scheme is robust to phylogenetic uncertainty and has recently been adopted by AF Bannikov, JC Tyler, D Arcila and G Carnevale [311].

\section{Suborder Triodontoidei}

Morphological synapomorphies: implied in various phylogenetic analyses by J. Tyler and colleagues (e.g., [23, 310, 311]).

Triodontidae

\section{Suborder Triacanthoidei}

Morphological synapomorphies: implied in various phylogenetic analyses by J. Tyler and colleagues (e.g., [23, 310, 311]).

Triacanthidae

Suborder Triacanthodoidei (100\%)

Morphological synapomorphies: implied in various phylogenetic analyses by J. Tyler and colleagues (e.g., $[23,310,311])$.

Triacanthodidae

Suborder Tetraodontoidei (100\%)

Morphological synapomorphies: implied in various phylogenetic analyses by J. Tyler and colleagues (e.g., [23, 310, 311]).

\section{Diodontidae}

Tetraodontidae

Suborder Moloidei (100\%)

Morphological synapomorphies: implied in various phylogenetic analyses by J. Tyler and colleagues (e.g., [23, 310, 311]).

Molidae

Suborder Balistoidei (100\%)

Morphological synapomorphies: implied in various phylogenetic analyses by J. Tyler and colleagues (e.g., [23, 310, 311]).

Balistidae

Monacanthidae 
Suborder Ostracioidei (100\%)

Morphological synapomorphies: implied in various phylogenetic analyses by J. Tyler and colleagues (e.g., $[23,310,311])$.

Aracanidae

Ostraciidae

\section{Order Pempheriformes (33\%)}

Morphological synapomorphies: lacking. Note that $\mathrm{Y}$ Tominaga [312] suggested that features of the cranium and swimbladder may be homologous in Pempheris and Glaucosoma; see also GD Johnson [50].

Comments: Although support for Pempheriformes is low, this clade has been obtained by several studies. Because Percophis brasiliensis (type species of Percophidae) is a Notothenioid [313], and the remaining "percophids" are in Pempheriformes, then the pempheriform "percophids" require family relocation. The subfamily Hemerocoetinae Kaup 1873 is now raised to the family level, following CE Thacker, TP Satoh, E Katayama, RC Harrington, RI Eytan and TJ Near [242]: "Additional proposed changes to the classification of Percomorpha include... recognition of Hemerocoetidae as a taxonomic family containing Matsubaraea, Enigmapercis, Pteropsaron, Acanthaphritis, and Osopsaron and the unsampled Dactylopsaron, Hemerocoetes, and Squamicreedia." See comments under Order Gobiiformes for notes regarding the placement of Creediidae and Hemerocoetidae in Pempheriformes rather than Trachinoidei.

Acropomatidae (not monophyletic in Fig. 2)

Banjosidae

Bathyclupeidae

Champsodontidae

Creediidae

Epigonidae

Glaucosomatidae

Howellidae

Lateolabracidae

Ostracoberycidae

Pempheridae

Pentacerotidae

"Percophidae" (see comments)

Polyprionidae

Symphysanodontidae

Not examined: Hemerocoetidae, Leptoscopidae

(assumed affinity with Creediidae; see [314]).

Order Centrarchiformes (98\%)

Morphological synapomorphies: lacking.

Comment: although the family name Cirrithidae Macleay 1841 is older than Centrarchidae Bleeker 1859, we retain the name Centrarchiformes for this order (in agreement with previous usage) but expand its membership following recent proposals [11, 315, 316].

Suborder Centrarchoidei (93\%)

Morphological synapomorphies: lacking.
Comments: inclusion of Enoploside in this suborder differs from the results obtained by $\mathrm{S}$ Lavoué, $\mathrm{K}$ Nakayama, DR Jerry, Y Yamanoue, N Yagishita, N Suzuki, M Nishida and M Miya [316]. Sinipercidae is recognized following $\mathrm{C} \mathrm{Li}, \mathrm{G}$ Orti and J Zhao [317] (formerly a synonym of Percichthyidae). As suggested by earlier classifications and confirmed by recent molecular studies (e.g., [318]), pygmy sunfishes (Elassoma) and sunfishes (centrarchids) are allied (placed in separate orders by EO Wiley and GD Johnson [57]).

Centrarchidae

Elassomatidae

Enoplosidae

Sinipercidae

Suborder Cirrhitoidei (similar to Cirrhitoidea sensu PH Greenwood [319], and CP Burridge and AJ Smolenski [320]; treated as Cirrhitiformes in previous versions of the classification) (97\%).

Morphological synapomorphies: see PH Greenwood [319].

Comment: the families Latridae, Chironemidae and Aplodactylidae are nested within Cheilodactylidae, rendering the latter non-monophyletic [92].

Aplodactylidae

Cheilodactylidae (not monophyletic in Fig. 2)

Chironemidae

Cirrhitidae

Latridae

Suborder Percichthyoidei (100\%)

Morphological synapomorphies: GD Johnson [59], but with a different circumscription (a series of nested synapomorphies uniting all members except Percalates).

Comment: percichthyoids and Percichthyidae sensu GD Johnson [59] are not monophyletic: the Australian species Percalates colonorum and Percalates novemaculeata are not closely related to other members of Percichthyidae $[8,315,316]$, so these species are herein placed in their own suborder [P. Unmack pers. comm.; 317]. Percalates is listed as a junior synonym of Macquaria by WN Eschmeyer [60], but the type species of Macquaria ( $M$. australasica) is closely related to other species of Macquaria (M. ambigua) within Percichthyidae sensu stricto, thus both are valid genus names [P. Unmack pers. comm.; 317]. Percichthyidae sensu stricto includes Percilia (formerly placed in its own family, Perciliidae).

Percichthyidae

Suborder Percalatoidei (100\%)

Morphological synapomorphies: lacking.

Comment: formal description of a new family for Percalates is required to comply with the ICZN.

"Percalatidae" (see comment)

Suborder Terapontoidei (= Clade "h2" of N Yagishita, M Miya, Y Yamanoue, SM Shirai, K Nakayama, N Suzuki, TP Satoh, K Mabuchi, M Nishida and T Nakabo 
[321]; = Terapontiformes in previous versions of the classification) (99\%)

Morphological synapomorphies: lacking for current circumscription. GD Johnson and RA Fritzsche [322] cite nerve pattern evidence uniting all but one of the families listed here (Dichistiidae) plus other groups currently placed in Pelagiaria (Arripdidae and stromateoids).

Comment: The families Girellidae, Microcanthidae and Scorpididae are herein recognized following several recent studies [321, 323-327]; these are listed as subfamilies of Kyphosidae in $\mathrm{R}$ Van Der Laan, WN Eschmeyer and R Fricke [62] and JS Nelson, T Grande and MVH Wilson [42].

Dichistiidae

Girellidae

Kuhliidae

Kyphosidae

Oplegnathidae

Terapontidae

Not examined: Microcanthidae, Scorpididae.

Order Perciformes (= Serraniformes sensu B Li, A Dettai, C Cruaud, A Couloux, M Desoutter-Meniger and G Lecointre [80], and A-C Lautredou, H Motomura, C Gallut, C Ozouf-Costaz, C Cruaud, G Lecointre and A Dettai [328]) (93\%)

Morphological synapomorphies: lacking.

Comments: although Perciformes has been traditionally regarded as a "taxonomic waste basket" (e.g., [41, 42, $50,51,57-59]$ ), the first version of this classification [8] proposed for the first time a monophyletic definition of the order based on robust molecular analyses. Compared to classification by other authors, the revised circumscription of Perciformes reduces significantly the number of included taxa, while retaining remarkable diversity that is now organized into several suborders and infraorders. Our definition comprises 61 perciform families, including species assigned by previous classifications to the orders Scorpaeniformes, Cottiformes, and Trachiniformes (no longer validated as orders herein).

Suborder Bembropoidei, new (100\%)

Morphological synapomorphies: lacking.

Comment: This suborder is newly classified to accommodate the family Bembropidae. Bembropidae is recognized following WL Smith and MT Craig [58]; it is a synonym of Percophidae according to R Van Der Laan, WN Eschmeyer and R Fricke [62].

Bembropidae

\section{Suborder Normanichthyoidei}

Morphological synapomorphies: see $\mathrm{M}$ Yabe, and $\mathrm{T}$. Uyeno. [329].

Comment: this suborder is classified following $\mathrm{R}$ Van Der Laan, WN Eschmeyer and R Fricke [62] and JS Nelson, T Grande and MVH Wilson [42].
Not examined: Normanichthyidae.

\section{Suborder Serranoidei (64\%)}

Morphological synapomorphies: see GD Johnson [330], C Baldwin and GD Johnson [331], but with a different circumscription (including Niphon).

Comments: we do not recognize Epinephelidae as a separate family, following WL Smith and MT Craig [58] and KY Ma, MT Craig, JH Choat and L van Herwerden [332]. The main justification for such nomenclatural change was that Smith and Craig's phylogenetic analysis failed to resolve the monophyly of serranids (including epinephelines, anthiines and serranines); however, they did not conduct a topology test to ask whether this null hypothesis is rejected by their data. Our large-scale analysis supports the monophyly of Serranidae (excluding Niphon; see comments under Percoidei below), albeit with low support. Also, while elevating Epinephelinae to family is a minor nomenclatural change, this rearrangement creates confusion for fish managers and conservation biologists given the commercial importance of groupers and the endangered status of many species.

\section{Serranidae}

Suborder Percoidei, restricted circumscription (99\%) Morphological synapomorphies: lacking.

Comments: A-C Lautredou, H Motomura, C Gallut, C Ozouf-Costaz, C Cruaud, G Lecointre and A Dettai [328] obtained a clade uniting Percidae and Trachinidae with full support, based on the analysis of seven nuclear markers. Like with Perciformes, the restricted and monophyletic circumscription of Percoidei in this classification contrasts markedly with the long history of confusion regarding the limits and polyphyly of Percoidei (e.g., [50, 51, 58, 59]). Removal of Niphon from Serranidae (e.g., as in $[330,331]$ ) and placement in its own family (Niphonidae) is consistent with several other studies (e.g., [58, 333]).

Niphonidae

Percidae

Not examined: Trachinidae.

Suborder Notothenioidei $(=$ Nototheniiformes in EO Wiley and GD Johnson [57]) (100\%)

Morphological synapomorphies: see PA Hastings [334], EO Wiley and GD Johnson [57] (but with a different circumscription; see comment below).

Comment: Percophidae is herein placed in Notothenioidei following TJ Near, A Dornburg, RC Harrington, C Oliveira, TW Pietsch, CE Thacker, TP Satoh, E Katayama, PC Wainwright, JT Eastman, et al. [313]; see comments above under Pempheriformes.

Artedidraconidae

Bathydraconidae (not monophyletic here; but see [335])

Bovichtidae

Channichthyidae 
Eleginopsidae

Harpagiferidae

Nototheniidae (not monophyletic in Fig. 2)

Pseudaphritidae

Not examined: Percophidae.

Suborder Scorpaenoidei (72\%)

Morphological synapomorphies: lacking. Phylogenetic analysis on all or part of various scorpaenoid families (e.g., [336-338]) vary to a greater or lesser degree than the results presented here.

Comment: nine families now included in Scorpaenoidei were listed in previous versions of this classification as not examined under Perciformes. See also $\mathrm{H}$ Imamura [336].

Scorpaenidae (not monophyletic in Fig. 2)

Sebastidae

Setarchidae

Synanceiidae

Tetrarogidae

Not examined: Apistidae, Aploactinidae,

Congiopodidae, Eschmeyeridae, Gnathanacanthidae,

Neosebastidae, Pataecidae, Perryenidae (see [339]),

Zanclorhynchidae.

Suborder Platycephaloidei (= Bembroidei in previous versions) (26\%)

Morphological synapomorphies: lacking (see comments).

Comment: previous versions of this classification included Bembridae and Parabembridae in the suborder Bembroidei, which we now expand to also include Hoplichthyidae, Platycephalidae and Plectrogeniidae (previously listed as suborder-level incertae sedis in Perciformes) - a well-supported clade in our analysis (100\% BS). We now name this taxon Platycephaloidei in accordance to other classifications (e.g., [336, 340]). Note that the family composition differs from that in other studies as Peristediidae and Triglidae are herein placed in a different suborder (Triglioidei).

Bembridae

Hoplichthyidae

Parabembridae

Platycephalidae

Not examined: Plectrogeniidae (see [336]).

Suborder Triglioidei sensu DS Jordan [341] (100\%)

Morphological diagnosis: SA Mandrytsa [338] presents synapomorphies; other results by H Imamura [336], and H Imamura [340] differ significantly from ours.

Peristediidae

Triglidae

Suborder Cottoidei (= Cottimorpha sensu Li, A Dettai, C Cruaud, A Couloux, M Desoutter-Meniger and G Lecointre [80]) (100\%)

Morphological synapomorphies: H Imamura, S Shirai and M Yabe [342].
Comment: we have chosen to recognize clades within this suborder as infraorders, adopting the ending "-ales" for this rank. Gasterosteales and Zoarcales have been grouped in a clade named Zoarciformes by B Li, A Dettai, C Cruaud, A Couloux, M DesoutterMeniger and $\mathrm{G}$ Lecointre [80].

Infraorder Anoplopomatales (= Anoplopomatoidei in previous classifications).

Morphological synapomorphies: H Imamura, S Shirai and M Yabe [342].

Anoplopomatidae

Infraorder Zoarcales (= Zoarcoidei in previous classifications) (100\%)

Morphological synapomorphies: ME Anderson [343], I Imamura and M Yabe [337].

Anarhichadidae

Bathymasteridae (not monophyletic in Fig. 2)

Cryptacanthodidae

Pholidae

Stichaeidae (not monophyletic in Fig. 2).

Zaproridae

Zoarcidae

Not examined: Eulophiidae [42, 344], Ptilichthyidae,

Scytalinidae.

Infraorder Gasterosteales (similar to Gasterosteoidei in other classifications, but excluding Indostomidae) (100\%)

Morphological synapomorphies: $\mathrm{R}$ Britz and GD Johnson [252] and EO Wiley and GD Johnson [57] provided synapomorphies for this clade but their diagnosis included Indostomidae, now placed in the series Anabantaria.

Aulorhynchidae

Gasterosteidae

Hypoptychidae

Infraorder Zaniolepidoales (= Zaniolepidoidei sensu WL Smith and MS Busby [345]).

Morphological synapomorphies: WL Smith and MS Busby [345], H Imamura, S Shirai and M Yabe [342]

Zaniolepididae (formerly a subfamily of

Hexagrammidae [62, 345])

Infraorder Hexagrammales (100\%) (= Hexagrammoidei in previous classifications)

Morphological synapomorphies: WL Smith and MS Busby [345].

Comment: Hexagrammidae as formerly defined is not monophyletic. We now split it into two families (formerly subfamilies): Hexagrammidae (sensu stricto) and Zaniolepididae [345-347]. As in previous cottoid classifications, these families are placed in their own infraorders (note that previous classifications use suborders instead of infraorders).

Hexagrammidae (sensu stricto; following [345])

Infraorder Cottales (99\%) (= Cottoidei sensu WL Smith and MS Busby [345]) 
Morphological synapomorphies: WL Smith and MS Busby [345].

Comments: WL Smith and MS Busby [345] changed the membership of Agonidae (now including the former Hemitripteridae), Cottidae (now including the former Abyssocottidae, Comephoridae, and Cottocomephoridae), and Psycholutridae (now including the former Bathylutichthyidae and many marine genera previously placed in Cottidae) to achieve monophyly of these families. Our phylogenetic results support their revised circumscription.

Agonidae

Cottidae

Cyclopteridae

Liparidae

Psychrolutidae

Scorpaenichthyidae

Trichodontidae

Not examined: Jordaniidae (following [345]) and

Rhamphocottidae (includes the former Ereuniidae; see [345]).

Superclass Sarcopterygii (58\%)

Morphological synapomorphies: see $\mathrm{R}$ Cloutier and $\mathrm{P}$ Ahlberg [348], HP Schultze and R Cloutier [349], M $\mathrm{Zhu}, \mathrm{X} \mathrm{Yu}$ and P Janvier [118].

Comment: Phylogenetic studies on sarcopterygians, based on morphological evidence, include both fossil and extant taxa. Some ranks below are thus redundant in content when only extant taxa are considered (e.g., Dipnomorpha, Ceratodontae and Ceratodontiformes).

Class Coelacanthimorpha (= Actinistia).

Morphological synapomorphies: see $\mathrm{R}$ Cloutier and $\mathrm{P}$ Ahlberg [348], H Dutel, JG Maisey, DR Schwimmer, P Janvier, M Herbin and G Clément [350] and G Arratia and HP Schultze [351] (extant taxa only).

\section{Order Coelacanthiformes}

Morphological synapomorphies: same as Coelacanthimorpha (extant taxa only).

Latimeriidae

Class Dipnotetrapodomorpha (100\%)

Morphological synapomorphies: $\mathrm{R}$ Cloutier and $\mathrm{P}$ Ahlberg [348].

Comment: recent genomic evidence supports the sister-group relationship between lungfishes and tetrapods [352, 353].

Subclass Dipnomorpha

Morphological synapomorphies: see HP Schultze and KSW Campbell [354], WE Bemis [355], R Cloutier and P Ahlberg [348], G Arratia, HP Schultze and J Casciotta [356] (extant taxa only).

Superorder Ceratodontae (= Dipnoi)

Morphological synapomorphies: same as Dipnomorpha (extant taxa only).

Order Ceratodontiformes
Morphological synapomorphies: same as Dipnomorpha (extant taxa only).

\section{Suborder Ceratodontoidei}

Morphological synapomorphies: see Cloutier and P Ahlberg [342].

Neoceratodontidae

Suborder Lepidosirenoidei (100\%)

Morphological synapomorphies: see Cloutier and P Ahlberg [342].

Lepidosirenidae

Protopteridae

Subclass Tetrapodomorpha $(100 \%)$

\section{Conclusions}

This update of the phylogenetic classification of bony fishes is substantially improved, implementing over a hundred changes (Additional file $3 \mathrm{~B}$ ) relative to the first version published in 2013 [8]. The updated classification is based on a global phylogenetic tree assembled from four different phylogenetic studies that collectively resolve the placement for nearly 2000 species representing 410 families ( $80 \%$ of the total) of fishes. Citations have been included to refer readers to morphological studies that provide evidence for the monophyly of specific groups, where available. A total of 514 families of bony fishes in 72 orders and 79 suborders are classified in the current version. Several families, however, remain unexamined or lack phylogenetic resolution. Comments are also included to support taxonomic decisions and an exhaustive comparison with conflicting taxonomic groups proposed by others is presented. In summary, rather than maintaining the taxonomic status quo that that has prevailed in ichthyology for decades, this classification uses an explicit and robust phylogenetic framework based on a large-scale phylogenetic backbone as well as on multiple recent, clade-specific studies that continue to improve our knowledge of the fish Tree of Life.

\section{Additional files}

Additional file 1: $\mathrm{R}$ code (including newick file examples) used for grafting crown clades into the backbone tree. (ZIP $110 \mathrm{~kb}$ )

Additional file 2: Complete tree in newick format. See details under legend of Fig. 2. (TRE 125 kb)

Additional file 3: (A) Comment-free classification; (B) list of changes. (DOCX 104 kb)

Additional file 4: Table S1. Spreadsheet with the complete classification. (XLSX $130 \mathrm{~kb}$ )

Additional file 5: Figure S1. High resolution image of Figure 1. (PDF $1120 \mathrm{~kb})$

Additional file 6: Figure S2. High resolution image of Figure 2. (PDF $4040 \mathrm{~kb}$ )

\section{Acknowledgments}

We wish to acknowledge G. David Johnson for reviewing the initial manuscript and then agreeing to review the revision. Dave's insistence that we pay closer 
attention to the morphological evidence, both supporting and conflicting our conclusions, has resulted in a much improved and more complete classification. For that he has our deepest thanks. We also thank W. Leo Smith, M. Tan, S. Longo, C. Stout, J. Armbruster, E. Ribeiro, R. Rivero, C. Pedraza, L. Hughes and D. Arcila for additional comments and suggestions on the classification.

\section{Funding}

This work is supported by National Science Foundation (NSF) grants to R.B.R. (DEB-147184, DEB-1541491), E.O.W. (NSF DEB-0732819), and G.O. (DEB-1457426 and DEB-1541554), and JSPS/MEXT JSPS KAKENHI grants to M.M. (22,370,035 and $26,291,083)$.

\section{Availability of data and materials}

All supporting data are included as additional files in the form of Additional files $1,2,3$ and 4 .

\section{Authors' contributions}

All authors contributed intellectually to the work and approved the submission.

\section{Competing interests}

The authors declare that they have no competing interests.

\section{Ethics approval and consent to participate}

Not applicable.

\section{Consent for publication}

Not applicable.

\section{Publisher's Note}

Springer Nature remains neutral with regard to jurisdictional claims in published maps and institutional affiliations.

\section{Author details}

'Department of Biology, University of Puerto Rico, Río Piedras, P.O. Box 23360, San Juan, PR 00931, USA. ²Department of Vertebrate Zoology, National Museum of Natural History, Smithsonian Institution, Washington, DC, USA. ${ }^{3}$ Biodiversity Institute and Department of Ecology \& Evolutionary Biology, University of Kansas, Lawrence, KS, USA. ${ }^{4}$ Sam Houston State Natural History Collections, Sam Houston State University, Huntsville, Texas, USA. ${ }^{5}$ Universidad Nacional de Colombia sede Caribe, Cecimar, El Rodadero, Santa Marta, Magdalena, Colombia. ${ }^{6}$ FishBase Information and Research Group, Los Baños, Philippines. ${ }^{7}$ Department Ecology and Environmental Sciences, Natural History Museum and Institute, Chiba, Japan. ${ }^{8}$ Institut de Systématique, Evolution, Biodiversité (ISYEB), Muséum National d'Histoire Naturelle, Paris, France. ${ }^{9}$ Department of Biology, The George Washington University, Washington, DC, USA

Received: 6 December 2016 Accepted: 26 April 2017

Published online: 06 July 2017

\section{References}

1. Linnaeus C: Philosophia Botanica. Stockholm \& Amsterdam; 1751.

2. Darwin CR. On the Origin of Species by Means of Natural Selection, Or, the Preservation of Favoured Races in the Struggle for Life. London: John Murray, Albemarle Street; 1859.

3. Hillis D: Personal communication. 2015. In: http://www.facebook.com/ Accessed on 30 Apr 2015.

4. Zuckerkandl E, Pauling L. Molecules as documents of evolutionary history. J Theor Biol. 1965:8:357-66.

5. Nelson G. Origin and diversification of teleostean fishes. Ann N Y Acad Sci. 1969;167:18-30

6. Greenwood PH, Rosen DE, Weitzman SH, Myers GS. Phyletic studies of teleostean fishes, with a provisional classification of living forms. Bull Am Mus Nat Hist. 1966;131(4):339-456.

7. Berg LS: Classification of fishes, both recent and fossil, vol. 5 (part 2): Trudy Zoologiceskogo Instituta, Akademii Nauk SSSR, Moskva, Leningrad; 1940.

8. Betancur-R R, Broughton RE, Wiley EO, Carpenter K, Lopez JA, Li C, et al. The tree of life and a new classification of bony fishes. PLoS Currents Tree of Life. 2013; Edition 1
9. Broughton RE, Betancur-R R, Li C, Arratia G, Orti G. Multi-locus phylogenetic analysis reveals the pattern and tempo of bony fish evolution. PLOS Currents Tree of Life. 2013; Edition 1

10. Near TJ, Eytan Rl, Dornburg A, Kuhn KL, Moore JA, Davis MP, et al. Resolution of ray-finned fish phylogeny and timing of diversification. Proc Natl Acad Sci. 2012;109(34):13698-703.

11. Near TJ, Dornburg A, Eytan Rl, Keck BP, Smith WL, Kuhn KL, et al. Phylogeny and tempo of diversification in the superradiation of spiny-rayed fishes. Proc Natl Acad Sci. 2013;110(31):12738-43.

12. Parham JF, Donoghue PC, Bell CJ, Calway TD, Head JJ, Holroyd PA, et al. Best practices for justifying fossil calibrations. Syst Biol. 2012;61(2): 346-59.

13. Inoue JG, Miya M, Venkatesh B, Nishida M. The mitochondrial genome of Indonesian coelacanth Latimeria menadoensis (Sarcopterygii :

Coelacanthiformes) and divergence time estimation between the two coelacanths. Gene. 2005;349:227-35.

14. Matsuura K, Nishida M. The mitochondrial genome spotted green pufferfish Tetraodon nigroviris (Teleostei: Tetraodontiformes) and divergence time estimation among model organisms in fishes. Gene Genet Syst. 2006:81:29-39.

15. Gauthier J, Kluge AG, Rowe T. Amniote phylogeny and the importance of fossils. Cladistics. 1988:4:105-209.

16. Grande L, Bemis WE. A comprehensive phylogenetic study of amiid fishes (Amiidae) based on comparative skeletal anatomy. An empirical search for interconnected patterns of natural history. Journal of Vertebrate Paleontology (Memoir 4, supplement). 1998;18(1):690.

17. Arratia G. The monophyly of Teleostei and stem-group teleosts. Consensus and disagreements. In: Arratia G, Schultze HP, editors. Mesozoic Fishes 2 - Systematics and Fossil Record. München: Verlag Dr. F. Pfeil; 1999. p. 265-334.

18. Otero O. Anatomy, systematics and phylogeny of both Recent and fossil latid fishes (Teleostei, Perciformes, Latidae). Zool J Linnean Soc. 2004;141(1):81-133.

19. Tyler JC, Santini F. A phylogeny of the fossil and extant zeiform-like fishes, Upper Cretaceous to recent, with comments on the putative zeomorph clade (Acanthomorpha). Zool Scr. 2005:34(2):157-75.

20. Friedman M. The evolutionary origin of flatfish asymmetry. Nature. 2008 454(7201):209-12

21. Davis MP, Arratia G, Kaiser TM. The first fossil shellear and its implications for the evolution and divergence of the Kneriidae (Teleostei: Gonorynchiformes). In: Arratia G, Schultze H-P, MVH W, editors. Mesozoic Fishes 5 - Global Diversity and Evolution. Muenchen: Verlag Dr. F. Pfeil; 2013. p. 325-62.

22. Grande T, Poyato-Ariza FJ, Diogo R: Gonorynchiformes and ostariophysan relationships: Science Publishers; 2010.

23. Arcila D, Pyron R, Tyler C, Ortí G, Betancur-R R. An evaluation of fossil tipdating versus node-age calibrations in tetraodontiform fishes (Teleostei: Percomorphaceae). Mol Phylogenet Evol. 2015;82:131-45.

24. Davesne D, Gallut C, Barriel V, Janvier P, Lecointre G, Otero O. The phylogenetic intrarelationships of spiny-rayed fishes (Acanthomorpha, Teleostei, Actinopterygii): fossil taxa increase the congruence of morphology with molecular data. Front Ecol Evol. 2016:4:129.

25. Arratia G. Phylogenetic relationships of Teleostei: past and present. Estud Oceanol. 2000:19:19-51.

26. Albert JS, Johnson DM, Knouft JH. Fossils provide better estimates of ancestral body size than do extant taxa in fishes. Acta Zool. 2009:90:357-84.

27. Betancur-R R, Orti G, Pyron AR. Fossil-based comparative analyses reveal ancient marine ancestry erased by extinction in ray-finned fishes. Ecol Lett. 2015;18:441-50

28. Hunt G, Slater $\mathrm{G}$. Integrating paleontological and phylogenetic approaches to macroevolution. Annu Rev Ecol Evol Syst. 2016;47(1):null.

29. Clarke JT, Lloyd GT, Friedman M. Little evidence for enhanced phenotypic evolution in early teleosts relative to their living fossil sister group. Proc Natl Acad Sci. 2016;113(41):11531-6.

30. Dornburg A, Friedman M, Near TJ. Phylogenetic analysis of molecular and morphological data highlights uncertainty in the relationships of fossil and living species of Elopomorpha (Actinopterygii: Teleostei). Mol Phylogenet Evol. 2015;89:205-18

31. Säve-Söderbergh G. Some points of view concerning the evolution of the vertebrates and the classification of this group. Ark Zool. 1934;26:1-20.

32. Mayr E. Methods and Principles of Systematic Zoology. New York: McGrawHill; 1953.

33. Greenwood P, Miles R, Patterson C. Interrelationships of fishes. London: Academic Press; 1973. 
34. Smith WL. Promoting resolution of the percomorph bush: a reply to Mooi and Gill. Copeia. 2010;3:520-4.

35. Rosen DE. An essay on euteleostean classification. Am Mus Novit. 1985; 2827:1-57.

36. Lauder GV, Liem KF. The evolution and interrelationships of the actinopterygian fishes. Bulletin of the Museum of Comparative Zoology. 1983;150(95-197):103.

37. Stiassny M, Parenti L, Johnson G. Interrelationships of fishes. San Diego: Academic Press; 1996.

38. Nelson JS. Fishes of the world, First edition edn. Hoboken: John Wiley \& Sons; 1976.

39. Nelson JS. Fishes of the world, Second edition edn. Hoboken: John Wiley \& Sons; 1984.

40. Nelson JS. Fishes of the world. 3rd ed. Hoboken: John Wiley \& Sons; 1994.

41. Nelson JS. Fishes of the world. 4th ed. Hoboken: John Wiley \& Sons; 2006.

42. Nelson JS, Grande T, Wilson MVH. 5th ed. Fishes of the World. Hoboken: John Wiley \& Sons; 2016

43. Rosen DE. Interrelationships of higher euteleostean fishes. In: Greenwood PH, Miles RS, Patterson C, editors. Interrelationships of fishes. London: Academic Press; 1973. p. 397-513.

44. Patterson C. The contribution of paleontology to teleostean phylogeny. In: Hecht MK, Goody PC, Hecht BM, editors. Major patterns in vertebrate evolution. New York; 1977. p. 579-643.

45. Arratia G. Basal teleosts and teleostean phylogeny. Palaeo Ichthyologica. 1997:7:1-168.

46. Arratia G. Complexities of early Teleostei and the evolution of particular morphological structures through time. Copeia. 2015:103(4):999-1025.

47. Patterson C, Rosen DE. Review of ichthyodectiform and other Mesozoic teleost fishes and the theory and practice of classifying fossils. Bull Am Mus Nat Hist. 1977:158:83-172.

48. Arratia G. The Clupeocephala re-visited: Analysis of characters and homologies. Revista de Biologia Marina \& Oceanografia. 2010;45(Special issue):635-57.

49. Johnson GD, Patterson C. Relationships of lower euteleostean fishes. In: ML S, Parenti LR, Johnson GD, editors. Interrelationships of fishes. San Diego: Academic Press; 1996. p. 251-332.

50. Johnson GD. Percomorph phylogeny: progress and problems. Bull Mar Sci. 1993:52(1):3-28.

51. Johnson GD, Patterson C. Percomorph phylogeny: a survey of acanthomorphs and a new proposal. Bull Mar Sci. 1993;52(1):554-626.

52. Stiassny MLJ, Moore JA. A review of the pelvic girdle of atherinomorph fishes. Zool J Linnean Soc. 1992;104:209-42.

53. Moore JA. Phylogeny of the Trachichthyiformes (Teleostei: Percomorpha), Bull Mar Sci. 1993;52(1):114-36.

54. Nelson G. Phylogeny of major fish groups. In: Fernholm B, Bremer K, Brundin L, Jörnvall H, Rutberg L, Wanntorp HE, editors. The Hierarchy of Life. Amsterdam: Elsevier Science; 1989. p. 325-36.

55. Chakrabarty P. The Transitioning state of systematic ichthyology. Copeia. 2010;2010(3):513-5.

56. Wiley EO, Chakrabarty P, Craig MT, Davis MP, Holcroft NI, Mayden RL, et al. Will the real phylogeneticists please stand up? Zootaxa. 2011;2946:7-16.

57. Wiley EO, Johnson GD. A teleost classification based on monophyletic groups. In: Nelson JS, Schultze HP, MVH W, editors. Origin and Phylogenetic Interrelationships of Teleosts. München: Verlag Dr. F. Pfeil; 2010. p. 123-82.

58. Smith WL, Craig MT. Casting the percomorph net widely: The importance of broad taxonomic sampling in the search for the placement of serranid and percid fishes. Copeia. 2007;2007(1):35-55.

59. Johnson GD. Percoidei: development and relationships. In: Moser $H_{\text {, }}$ Richards W, Cohen D, Fahay M, Kendell Jr A, Richardson S, editors. Ontogeny and Systematics of Fishes. Lawrence: American Society of Ichthyologists and Herpetologists Special Publication; 1984. p. 438-47.

60. Catalog of Fishes. http://research.calacademy.org/redirect?url=http:// researcharchive.calacademy.org/research/lchthyology/catalog/fishcatmain. asp. Accessed on 30 June 2016

61. Eschmeyer WN. Catalog of Fishes, vol. 1-3: California Academy of Sciences; 1998.

62. Van Der Laan R, Eschmeyer WN, Fricke R. Family-group names of Recent fishes. Zootaxa. 2014;3882(1):230.

63. Parenti L. Book review: Fishes of the World, third edition. Copeia. 1995;1:262-4.

64. Lé HLV, Lecointre G, Perasso R. A $28 \mathrm{~S}$ rRNA-based phylogeny of the gnathostomes: first steps in the analysis of conflict and congruence with morphologically based cladograms. Mol Phylogenet Evol. 1993;2: $31-51$.
65. Lecointre G, Nelson G. Clupeomorpha, sister-group of Ostariophysi. In: Stiassny M, Parenti $L$, Johnson $G$, editors. Interrelationships of fishes. San Diego: Academic Press; 1996. p. 193-207.

66. Arratia G. Reassessment of the phylogenetic relationships of Jurassic teleosts and their implications in teleostean phylogeny. In: Arratia G, Viohl G, editors. Mesozoic Fishes — Systematics and Paleoecology. Verlag Dr. F. Pfeil: München; 1996.

67. Miya M, Nishida M. Organization of the mitochondrial genome of a deepsea fish, Gonostoma gracile (Teleostei: Stomiiformes): first example of transfer RNA gene rearrangements in bony fishes. Marine biotechnology (New York, NY). 1999;1(5):416-0426.

68. Miya M, Takeshima H, Endo H, Ishiguro N, Inoue J, Mukai T, et al. Major patterns of higher teleostean phylogenies: a new perspective based on 100 complete mitochondrial DNA sequences. Mol Phylogenet Evol. 2003;26(1):121-38.

69. Miya M, Satoh T, Nishida M. The phylogenetic position of toadfishes (order Batrachoidiformes) in the higher ray-finned fish as inferred from partitioned Bayesian analysis of 102 whole mitochondrial genome sequences. Biol J Linn Soc. 2005;85:289-306.

70. Miya M, Holcroft NI, Satoh TP, Yamaguchi M, Nishida M, Wiley EO. Mitochondrial genome and a nuclear gene indicate a novel phylogenetic position of deep-sea tube-eye fish (Stylephoridae). Ichthyol Res. 2007;54(4):323-32.

71. Yamanoue Y, Miya M, Matsuura K, Katoh M, Sakai H, Nishida M. A new perspective on phylogeny and evolution of tetraodontiform fishes (Pisces: Acanthopterygii) based on whole mitochondrial genome sequences: basal ecological diversification? BMC Evol Biol. 2008;8(1):212.

72. Nakatani M, Miya M, Mabuchi K, Saitoh K, Nishida M. Evolutionary history of Otophysi (Teleostei), a major clade of the modern freshwater fishes: Pangaean origin and Mesozoic radiation. BMC Evol Biol. 2011;11:177.

73. Miya M, Nishida M. The mitogenomic contributions to molecular phylogenetics and evolution of fishes: a 15-year retrospect. Ichthyol Res. 2015:29-71.

74. Li C, Orti G, Zhang G, Lu G. A practical approach to phylogenomics: the phylogeny of ray-finned fish (Actinopterygii) as a case study. BMC Evol Biol. 2007;7(1):44

75. Chen W, Bonillo C, Lecointre G. Repeatability of clades as a criterion of reliability: a case study for molecular phylogeny of Acanthomorpha (Teleostei) with larger number of taxa. Mol Phylogenet Evol. 2003;26:262-88.

76. López JA, Chen WJ, Orti G. Esociform phylogeny. Copeia. 2004;2004(3):449-64.

77. Lundberg JG, Sullivan JP, Rodiles-Hernández R, Hendrickson DA. Discovery of African roots for the Mesoamerican Chiapas catfish, Lacantunia enigmatica, requires an ancient intercontinental passage. Proc Acad Natl Sci Phila. 2007;156:39-53.

78. Li C, Lu G, Orti G. Optimal data partitioning and a test case for ray-finned fishes (actinopterygii) based on ten nuclear Loci. Syst Biol. 2008;57(4):519-39.

79. Dettai A, Lecointre G. New insights into the organization and evolution of vertebrate IRBP genes and utility of IRBP gene sequences for the phylogenetic study of the Acanthomorpha (Actinopterygii: Teleostei). Mol Phylogenet Evol. 2008;48(1):258-69.

80. Li B, Dettai A, Cruaud C, Couloux A, Desoutter-Meniger M, Lecointre G. RNF213, a new nuclear marker for acanthomorph phylogeny. Mol Phylogenet Evol. 2009;50(2):345-63.

81. Mayden RL, Chen WJ. The world's smallest vertebrate species of the genus Paedocypris: a new family of freshwater fishes and the sister group to the world's most diverse clade of freshwater fishes (Teleostei: Cypriniformes). Mol Phylogenet Evol. 2010;57(1):152-75.

82. Li C, Betancur-R R, Smith WL, Orti G. Monophyly and interrelationships of snook and barramundi (Centropomidae sensu Greenwood) and five new markers for fish phylogenetics. Mol Phylogenet Evol. 2011;60(3):463-71.

83. Oliveira C, Avelino GS, Abe KT, Mariguela TC, Benine RC, Orti G, et al. Phylogenetic relationships within the speciose family Characidae (Teleostei: Ostariophysi: Characiformes) based on multilocus analysis and extensive ingroup sampling. BMC Evol Biol. 2011;11:275.

84. Near TJ, Bossu CM, Bradburd GS, Carlson RL, Harrington RC, Hollingsworth PR Jr, et al. Phylogeny and temporal diversification of darters (Percidae: Etheostomatinae). Syst Biol. 2011;60(5):565-95.

85. Ishiguro NB, Miya M, Nishida M. Basal euteleostean relationships: a mitogenomic perspective on the phylogenetic reality of the "Protacanthopterygii". Mol Phylogenet Evol. 2003;27(3):476-88.

86. Saitoh K, Miya M, Inoue JG, Ishiguro NB, Nishida M. Mitochondrial genomics of ostariophysan fishes: perspectives on phylogeny and biogeography. J Mol Evol. 2003;56(4):464-72. 
87. Saitoh K, Sado T, Mayden RL, Hanzawa N, Nakamura K, Nishida M, et al. Mitogenomic evolution and interrelationships of the cypriniformes (Actinopterygii : Ostariophysi): The first evidence toward resolution of higher-level relationships of the world's largest freshwater fish clade based on 59 whole mitogenome sequences. J Mol Evol. 2006;63(6):826-41.

88. New and Revised Classification of Bony Fishes. Version 2: http://www. deepfin.org/Classification_v2.htm. Accessed 27 Nov 2013.

89. Mirande JM. Combined phylogeny of ray-finned fishes (Actinopterygii) and the use of morphological characters in large-scale analyses. Cladistics. 2016;

90. Rabosky DL, Santini F, Eastman J, Smith SA, Sidlauskas B, Chang J, et al. Rates of speciation and morphological evolution are correlated across the largest vertebrate radiation. Nat Commun. 2013;4:1958.

91. Phylogenetic Classification of Bony Fishes. Version 3. http://www.deepfin. org/Classification_v3.htm. Accessed 31 July 2014

92. Sanciangco MD, Carpenter KE, Betancur-R. R: Phylogenetic placement of enigmatic percomorph families (Teleostei: Percomorphaceae). Mol Phylogenet Evol 2015, 94:565-576.

93. Faircloth BC, McCormack JE, Crawford NG, Harvey MG, Brumfield RT, Glenn TC. Ultraconserved elements anchor thousands of genetic markers spanning multiple evolutionary timescales. Syst Biol. 2012;61(5):717-26.

94. Lemmon AR, Emme SA, Lemmon EM. 2012. Anchored hybrid enrichment for massively high-throughput phylogenomics. Syst Biol. 2012,61:727-744.

95. Li C, Hofreiter M, Straube N, Corrigan S, Naylor GJ. Capturing protein-coding genes across highly divergent species. BioTechniques. 2013;54(6):321-6.

96. Faircloth BC, Sorenson L, Santini F, Alfaro ME. A phylogenomic perspective on the radiation of ray-finned fishes based upon targeted sequencing of ultraconserved elements (UCEs). PLoS One. 2013;8(6):e65923.

97. Gilbert PS, Chang J, Pan C, Sobel EM, Sinsheimer JS, Faircloth BC, et al Genome-wide ultraconserved elements exhibit higher phylogenetic informativeness than traditional gene markers in percomorph fishes. Mol Phylogenet Evol. 2015:92:140-6.

98. Eytan RI, Evans BR, Dornburg A, Lemmon AR, Lemmon EM, Wainwright PC, et al. Are 100 enough? Inferring acanthomorph teleost phylogeny using Anchored Hybrid Enrichment. BMC Evol Biol. 2015;15:113.

99. McGee MD, Faircloth BC, Borstein SR, Zheng J, Darrin Hulsey C, Wainwright PC, et al. Replicated divergence in cichlid radiations mirrors a major vertebrate innovation. Proc Biol Sci. 2016:283:1822.

100. Harrington RC, Faircloth BC, Eytan Rl, Smith WL, Near TJ, Alfaro ME, et al. Phylogenomic analysis of carangimorph fishes reveals flatfish asymmetry arose in a blink of the evolutionary eye. BMC Evol Biol. 2016:16(1):224.

101. Arcila D, Ortí G, Vari RP, Armbruster JW, Stiassny MLJ, Ko K, et al. Genome wide interrogation advances resolution of recalcitrant groups in the Tree of Life. Nature Eco Evo. 2017:1.

102. Stout CC, Tan M, Lemmon AR, Lemmon EM, Armbruster JW. Resolving Cypriniformes relationships using an anchored enrichment approach. BMC Evol Biol. 2016;16(1):244.

103. Longo SJ, Faircloth BC, Meyer A, Westneat MW, Alfaro ME, Wainwright PC: Phylogenomic analysis of a rapid radiation of misfit fishes (Syngnathiformes) using ultraconserved elements Mol Phylogenet Evol; 113:33-48.

104. Bernardi G, Wiley EO, Mansour H, Miller MR, Orti G, Haussler D, et al. The fishes of Genome 10K. Mar Genomics. 2012;7:3-6.

105. Braasch I, Peterson SM, Desvignes T, McCluskey BM, Batzel P, Postlethwait JH. A new model army: emerging fish models to study the genomics of vertebrate Evo-Devo. J Exp Zool B Mol Dev Evol. 2015; 324(4):316-41.

106. Malmstrøm M, Matschiner M, Tørresen OK, Star B, Snipen LG, Hansen TF, et al. Evolution of the immune system influences speciation rates in teleost fishes. Nat Genet. 2016:48:1204-10.

107. Sun Y, Huang Y, Li X, Baldwin CC, Zhou Z, Yan Z, et al. Fish-T1K (Transcriptomes of 1,000 Fishes) Project: large-scale transcriptome data for fish evolution studies. Gigascience. 2016;5:18

108. Pasquier J, Cabau C, Nquyen T, Jouanno E, Severac D, Braasch I, et al. Gene evolution and gene expression after whole genome duplication in fish: the PhyloFish database. BMC Genomics. 2016;17:368.

109. Ruggiero MA, Gordon DP, Orrell TM, Bailly N, Bourgoin T, Brusca RC, et al. A Higher Level Classification of All Living Organisms. PLoS One. 2015;10(4): e0119248.

110. R: a Language and environment for statistical computing [http://www.rproject.org/.]
111. Paradis E, Claude J, Strimmer K. APE: analyses of phylogenetics and evolution in R language. Bioinformatics. 2004;20:289-90.

112. Revell $\amalg$. phytools: an R package for phylogenetic comparative biology (and other things). Methods Ecol Evol. 2012;3(2):217-23.

113. Species of Fishes by family/subfamily. http://research.calacademy.org/ ichthyology/catalog/family. Accessed 3 July 2016.

114. Arratia G, Schultze HP. Palatoquadrate and its ossifications: development and homology within osteichthyans. J Morphol. 1991;208:1-81.

115. Janvier P. Early vertebrates. Oxford: Oxford University Press; 1996.

116. Ahlberg P. Major Events in Early Vertebrate Evolution: Paleontology, Phylogeny, Genetics, and Development. London: Taylor and Francis; 2001.

117. Zhu M, Schultze HP: Interrelationships of basal osteichthyans. In: Major Events in Early Vertebrate Evolution: Paleontology, Phylogeny, Genetics, and Development. Edited by Ahlberg P. London: Taylor and Francis; 2001;289-314.

118. Zhu $M, Y u X$, Janvier $P$. A primitive fossil fish sheds light on the origin of bony fishes. Nature. 1999;397(6720):607-10.

119. Patterson C. Morphology and interrelationships of primitive actinopterygians. Am Zool. 1982;22:241-59.

120. Coates Ml. Actinopterygians the namurian of bearsden, scotland, with comments on early actinopterygian neurocrania. Zool J Linnean Soc. 1998;122:27-59.

121. Schultze H-P, Cumbaa SL. Dialipina and the characters of basal actinopterygians. In: Ahlberg PE, editor. Major events in Early Vertebrate Evolution, Paleontology, Phylogeny, Genetics and Development. London and New York: Systematic Association Special Volume - Taylor \& Francis; 2001. p. 315-32.

122. Cloutier R, Arratia G. Early diversification of actinopterygians. In: Arratia G, MVH W, Cloutier R, editors. Recent Advances in the Origin and Early Radiation of Vertebrates. Munich: Verlag Dr. Friedrich Pfeil; 2004. p. 217-70.

123. Mickle K. The lower actinopterygian fauna from the Lower Carboniferous Albert shale formation of New Brunswick, Canada - A review of previously described taxa and a description of a new genus and species. Fossil Record. 2017;20:47-67.

124. Jarvik E. Basic Structure and Evolution of Vertebrates. New York: Academic Press; 1996

125. Britz R, Bartsch P. The myth of dorsal ribs in gnathostome vertebrates. Proc R Soc B Biol Sci. 2003;270:1-4.

126. Ward $A B$, Kley NJ. Effects of precaudal elongation on visceral topography in a basal clade of ray-finned fishes. Anat Rec Adv Integr Anat Evol Biol. 2012; 295(2):289-97.

127. Bartsch P, Britz R. A single micropyle in the eggs of the most basal living actinopterygian Polypterus (Actinopterygii, Polypteriformes). J Zool. 1997; 241:589-92.

128. Lund R, Poplin C. Cladistic analysis of the relationships of the terrasiids (Lower Carboniferous, Actinopterygians). J Vertebr Paleontol. 2002:22(3):480-6

129. Xu G-H, Gao K-Q, Finarelli JA. A revision of the Middle Triassic scanilepiform fish Fukonichthys longidorsalis from Xinjiang, China, with comments on the phylogeny of the Actinoptery. J Vertebr Paleontol. 2014;34(4):747-59.

130. Grande L, Bemis WE. Interrelationships of Acipenseriformes with comments on "Chondrostei". In: ML S, Parenti LR, Johnson GD, editors. Interrelationships of fishes. London: Academic Press; 1996. p. 85-115.

131. Bemis WE, Findeis EK, Grande L. An overview of Acipenseriformes. Environ Biol Fish. 1997:48:25-71.

132. Jamieson BG. Fish Evolution and Systematics: Evidence from Spermatozoa Cambridge: Cambridge University Press; 1991

133. Grande L: An empirical synthetic pattern study of gars (Lepisosteiformes) and closely related species, based mostly on skeletal anatomy. The resurrection of Holostei Copeia 2010, 10(2A suppl.):1-871.

134. López-Arbarello A. Phylogenetic interrelationships of ginglymodian fishes (Actinopterygii: Neopterygii). PLoS One. 2012;7(7):e39370.

135. Hurley IA, Mueller RL, Dunn KA, Schmidt EJ, Friedman M, Ho RK, et al. A new time-scale for ray-finned fish evolution. Proceedings of the Royal Society B-Biological Sciences. 2007;274(1609):489-98.

136. Arratia G. Morphology, taxonomy, and phylogeny of Triassic pholidophorid fishes (Actinopterygii, Teleostei). J Vertebr Paleontol. 2013;33(sup1):1-138.

137. Arratia G. New remarkable Late Jurassic teleosts from southern Germany: Ascaloboidae n. fam., its content, morphology, and phylogenetic relationships. Fossil Record. 2016;19:31-59.

138. Wiley EO. The phylogeny and biogeography of fossil and recent gars (Actinopterygii: Lepisosteidae). University of Kansas Museum of Natural History, Miscellaneous Publications. 1976;64:1-111. 
139. de MCC P. Teleostean monophyly. In: ML S, Parenti LR, Johnson GD, editors. Interrelationships of Fishes. San Diego: Academic Press; 1996. p. 147-62.

140. Britz R. Book review: Fishes of the World. Fifth edition. by J. S. Nelson, T. C. Grande \& M. V. W. Wilson. J Fish Biol. 2017;2017(90):451-9.

141. Inoue JG, Miya M, Tsukamoto K, Nishida M. A mitogenomic perspective on the basal teleostean phylogeny: resolving higher-level relationships with longer DNA sequences. Mol Phylogenet Evol. 2001;20(2):275-85.

142. Lavoué S, Miya M, Arnegard ME, Sullivan JP, Hopkins CD, Nishida M. Comparable ages for the independent origins of electrogenesis in African and South American weakly electric fishes. PLoS One. 2012;7(5):e36287.

143. Austin CM, Tan MH, Croft LJ, Hammer MP, Gan HM. Whole genome sequencing of the Asian arowana (Scleropages formosus) provides insights into the evolution of ray-finned fishes. Genome Biol Evol. 2015;7(10):2885-95.

144. Arratia G. The caudal skeleton of Jurassic teleosts: A phylogenetic analysis. In: Chang MM, Liu YH, Zhang GR, editors. Early Vertebrates and Related Problems in Evolutionary Biology. Beijing: Science Press; 1991. p. 249-340.

145. Arratia G. Remarkable teleostean fishes from the Late Jurassic of southern Germany and their phylogenetic relationships. Mitteilungen aus dem Museum für Naturkunde, Berlin, Geowissenschaftliche Reihe. 2000;3:137-79.

146. Arratia G. New teleostean fishes from southern Germany and the systematic problems concerning the 'pholidophoriforms'. Paläontol Z. 2000;74:113-43.

147. Arratia G. Critical analysis of the impact of fossils on teleostean phylogenies, especially that of basal teleosts. In: Elliott DK, Maisey JG, Yu X, Miao DS, editors. Morphology, Phylogeny and Paleobiogeography of Fossil Fishes. München: Verlag Dr. F. Pfeil; 2010. p. 247-74.

148. Shen M. Fossil "osteoglossomorphs" in East Asia and their implications in teleostean phylogeny. In: Arratia G, Viohl G, editors. Mesozoic Fishes Systematics and Paleoecology. München: Verlag Dr. F. Pfeil; 1996. p. 261-72.

149. Zhang YJ. Morphology and phylogenetic relationships of Kuntulunia Ma 1980 (Teleostei: Osteoglossomorpha). J Vertebr Paleontol. 1998;18:280-300.

150. Li G-Q, MVH W. Early divergence of Hiodontiformes sensu stricto in East Asia and phylogeny of some Late Mesozoic teleosts from China. In: Arratia G, Schultze H-P, editors. Mesozoic Fishes 2 - Systematics and Fossil Record. München: Verlag Dr. F. Pfeil; 1999. p. 369-84.

151. Li G-Q. New osteoglossomorphs (Teleostei) from the Upper Cretaceous and Lower Tertiary of North America and their phylogenetic significance. Edmonton: University of Alberta; 1995.

152. Li G-Q. A new species of Late Cretaceous osteoglossid (Teleostei) from the Oldman formation of Alberta, Canada, and its phylogenetic relationships. In: Arratia G, Viohl G, editors. Mesozoic Fishes — Systematics and Paleoecology. Munich: Verlag Dr. Friedrich Pfeil; 1996. p. 285-98.

153. Santini F, Harmon L, Carnevale G, Alfaro M. Did genome duplication drive the origin of teleosts? A comparative study of diversification in ray-finned fishes. BMC Evol Biol. 2009;9(1):194.

154. Near TJ, Dornburg A, Kuhn KL, Eastman JT, Pennington JN, Patarnello T, et al. Ancient climate change, antifreeze, and the evolutionary diversification of Antarctic fishes. Proc Natl Acad Sci U S A. 2012;109(9):3434-9.

155. Bian C, Hu Y, Ravi V, Kuznetsova IS, Shen X, Mu X, et al. The Asian arowana (Scleropages formosus) genome provides new insights into the evolution of an early lineage of teleosts. Sci Rep. 2016;6:24501.

156. Forey PL. Interrelationships of elopomorph fishes. In: ML S, Parenti LR, Johnson GD, editors. Interrelationships of fishes. San Diego: Academic Press; 1996. p. 175-91.

157. Johnson GD, Britz R. Occipito-vertebral fusion in actinopterygians: conjecture, myth and reality. Part 2: Teleosts. In: Nelson JS, Schultze HP, MVH W, editors. Origin and Phylogenetic Interrelationships of Teleosts. München: Verlag Dr. F. Pfeil; 2010. p. 95-110.

158. Johnson GD, Ida H, Sakaue J, Sado T, Asahida T, Miya M. A 'living fossil' eel (Anguilliformes: Protanguillidae, fam. nov.) from an undersea cave in Palau. Proc Biol Sci B. 2012;279(1730):934-43.

159. Hilton EJ. Comparative osteology and phylogenetic systematics of fossil and living bony-tongue fishes (Actinopterygii, Teleostei, Osteoglossomorpha). Zool J Linnean Soc. 2003;137:1-100.

160. Zhang J-Y. Phylogeny of Osteoglossomorpha. Vert Pal Asiat. 2006;44(1):43-59.

161. Wilson MVH, Murray AM. Osteoglossomorpha: phylogeny, biogeography, and fossil record and the significance of key African and Chinese fossil taxa. Geol Soc Lond, Spec Publ. 2008;295(1):185-219.

162. Mattox SMT, Britz R, Toledo-Piza M. Skeletal development and ossification sequence of the characiform Salminus brasiliensis (Ostariophysi: Characidae). Ichthyol Explor Freshwaters. 2014;25(2):103-58.
163. Bird NC, Mabee PM. Developmental morphology of the axial skeleton of the zebrafish, Danio rerio (Ostariophysi: Cyprinidae). Developmental dynamics an official publication of the American Association of Anatomists. 2003; 228(3):337-57.

164. Bensimon-Brito A, Cancela ML, Huysseune A, Witten PE. Vestiges, rudiments and fusion events: the zebrafish caudal fin endoskeleton in an evo-devo perspective. Evolution \& development. 2012;14(1):116-27.

165. Wiley EO, Fuiten AM, Doosey MH, Lohman BK, Merkes C, Azuma M. The caudal skeleton of the zebrafish, Danio rerio, from a phylogenetic perspective: a polyural interpretation of homologous structures. Copeia. 2015;103(4):740-50

166. Schultze HP, Arratia G. The caudal skeleton of basal teleosts, its conventions, and some of its major evolutionary novelties in a temporal dimension. In: Arratia G, Schultze H-P, MVH W, editors. Mesozoic Fishes 5 - Global Diversity and Evolution. Muenchen: Verlag Dr. F. Pfeil; 2013. p. 187-246.

167. Grande L. Recent and fossil clupeomorph fishes with material for revision of the subgroups of clupeoids. Bull Amer Mus Natur Hist. 1985;181:231-372.

168. Di Dario F, de Pinna MCC. The supratemporal system and the pattern ofamification of cephalic sensory canals in Denticeps clupeoides (Denticipitidae, Teleostei): additional evidence for monophyly of Clupeiformes and Clupeoidei. Papéis Avulsos de Zoologia. 2006;46(10):107-23.

169. de Pinna MCC, Di Dario F. The branchial arches of the primitive clupeomorph fish, Denticeps clupeoides, and their phylogenetic implication (Clupeiformes, Denticipitidae). In: Nelson JS, Schultze HP, MVH W, editors. Origin and Phylogenetic Interrelationships of Teleosts. München: Verlag Dr. F. Pfeil; 2010. p. 251-68.

170. Li C, Orti G. Molecular phylogeny of Clupeiformes (Actinopterygii) inferred from nuclear and mitochondrial DNA sequences. Mol Phylogenet Evol. 2007;44(1):386-98

171. Lavoué S, Miya M, Musikasinthorn P, Chen WJ, Nishida M. Mitogenomic evidence for an Indo-West Pacific origin of the Clupeoidei (Teleostei: Clupeiformes). PLoS One. 2013;8(2):e56485.

172. Siebert DJ. Notes on the anatomy and relationships of Sundasalanx Roberts (Teleostei, Clupeidae), with descriptions of four new species from Borneo. Bulletin of The Natural History Museum Zoology Series. 1997;63:13-26.

173. Poulsen JY, Møller PR, Lavoué S, Knudsen SW, Nishida M, Miya M. Higher and lower-level relationships of the deep-sea fish order Alepocephaliformes (Teleostei: Otocephala) inferred from whole mitogenome sequences. Biol J Linn Soc. 2009;98(4):923-36.

174. Lavoué S, Miya M, Poulsen JY, Møller PR, Nishida M. Monophyly, phylogenetic position and inter-familial relationships of the Alepocephaliformes (Teleostei) based on whole mitogenome sequences. Mol Phylogenet Evol. 2008;47(3):1111-21.

175. Fink SV, Fink WL. Interrelationships of the Ostariophysan Fishes (Teleostei). Zool J Linnean Soc. 1981;72(4):297-353.

176. Fink SV, Fink WL. Interrelationships of ostariophysan fishes (Teleostei). In: ML S, Parenti LR, Johnson GD, editors. Interrelationships of fishes. San Diego: Academic Press; 1996. p. 209-49.

177. Poyato-Ariza FJ, Grande T, Diogo R. Gonorynchiform interrelationships: Historic Overview, Analysis, and Revised Systematics of the Group. In: Grande T, Poyato-Ariza FJ, Diogo R, editors. Gonorynchiformes and Ostariophysan Relationships. 338: Science Publishers; 2010. p. 227.

178. Grande T, Poyato-Ariza FJ. Phylogenetic relationships of fossil and recent gonorynchiform fishes (Teleostei: Ostariophysi). Zool J Linnean Soc. 1999; 125(2):197-238.

179. Chen WJ, Lavoué S, Mayden RL. Evolutionary origin and early biogeography of otophysan fishes (Ostariophysi: Teleostei). Evolution. 2013;67(8):2218-39.

180. Mabee PM, Grey EA, Arratia G, Bogutskaya N, Boron A, Coburn MM, et al. Gill arch and hyoid arch diversity and cypriniform phylogeny: Distributed integration of morphology and web-based tools. Zootaxa. 2012;2877:1-40.

181. Conway KW. Osteology of the South Asian Genus Psilorhynchus McClelland, 1839 (Teleostei: Ostariophysi: Psilorhynchidae), with investigation of its phylogenetic relationships within the order Cypriniformes. Zool J Linnean Soc. 2011(163):50-154

182. Chen WJ, Mayden RL. Molecular systematics of the Cyprinoidea (Teleostei: Cypriniformes), the world's largest clade of freshwater fishes: further evidence from six nuclear genes. Mol Phylogenet Evol. 2009:52(2):544-9.

183. Britz R, Conway K, Ruber L. Miniatures, morphology and molecules: Paedocypris and its phylogenetic position (Teleostei, Cypriniformes). Zool J Linnean Soc. 2014 
184. Siebert DJ. Interrelationships Among Families of the Order Cypriniformes (Teleostei). New York: City University of New York; 1987.

185. Chen WJ, Lheknim V, Mayden RL. Molecular phylogeny of the Cobitoidea (Teleostei: Cypriniformes) revisited: position of enigmatic loach Ellopostoma resolved with six nuclear genes. J Fish Biol. 2009;75(9):2197-208.

186. Kottelat M. Conspectus Cobitidum: an inventory of the loaches of the world (Teleostei: Cypriniformes: Cobitoidei). Raffles Bull Zool. 2012;26:1-199.

187. Yang L, Sado T, Vincent Hirt M, Pasco-Viel E, Arunachalam M, Li J, Wang X, Freyhof J, Saitoh K, Simons AM et al: Phylogeny and polyploidy: resolving the classification of cyprinine fishes (Teleostei: Cypriniformes). Mol Phylogenet Evol. 2015;85:97-116

188. Vari RP. Higher level phylogenetic concepts within Characiformes (Ostariophysi), a historical review. In: Malabarba LR, Reis RE, Vari RP, ZMS L, CAS L, editors. Phylogeny and Classification of Neotropical Fishes. Porto Alegre: EDIPUCRS; 1998. p. 111-22.

189. Chakrabarty P, Faircloth BC, Alda F, Ludt WB, McMahan CD, Near TJ, et al. Phylogenomic systematics of ostariophysan fishes: ultraconserved elements support the surprising non-monophyly of characiformes. Syst Biol. 2017; In press

190. Vari RP. Anatomy, relationships and classification of the families Citharinidae and Distichodontidae (Pisces: Characoidei). Bull Brit Mus (Natur Hist), Zool. 1979:36:261-344.

191. Tagliacollo VA, Bernt MJ, Craig JM, Oliveira C, Albert JS. Model-based total evidence phylogeny of Neotropical electric knifefishes (Teleostei, Gymnotiformes). Mol Phylogenet Evol. 2015;95:20-33.

192. Arratia G. Description of the primitive family Diplomystidae (Siluriformes, Teleostei, Pisces): morphology, taxonomy, and phylogenetic implications. Bonner Zoologische Monographien. 1987;24.

193. Mo T. Anatomy, relationships and systematics of the Bagridae (Teleostei: Siluroidei) with a hypothesis of siluroid phylogeny. Theses Zoologicae. 1991;17:1-216.

194. Arratia G. Development and variation of the suspensorium of primitive catfishes (Teleostei: Ostariophysi) and their phylogenetic relationships. Bonner Zoologische Monographien. 1992;32:1-149.

195. de MCC P. Higher-Level Phylogeny of the Siluriformes, with a New Classification of the Order, Ph.D. thesis. New York: City University of New York; 1993.

196. de Pinna MCC. Phylogenetic relationships of Neotropical Siluriformes (Teleostei: Ostariophysi): historical overview and synthesis of hypotheses. In: Malabarba LR, Reis RE, Vari RP, ZMS L, CAS L, editors. Phylogeny and Classification of Neotropical Fishes. EDIPUCRS: Porto Alegre; 1998.

197. Diogo R. Phylogeny, origin and biogeography of catfishes: support for a Pangean origin of 'modern teleosts' and reexamination of some Mesozoic Pangean connections between the Gondwanan and Laurasian supercontinents. Anim Biol. 2004;54(4):331-51.

198. Sullivan JP, Lundberg JG, Hardman M. A phylogenetic analysis of the major groups of catfishes (Teleostei : Siluriformes) using rag1 and rag2 nuclear gene sequences. Mol Phylogenet Evol. 2006;41(3):636-62.

199. Britz R, Kakkassery F, Raghavan R. Osteology of Kryptoglanis shajii, a stygobitic catfish (Teleostei: Siluriformes) from peninsular India, with diagnosis of a new family Kryptoglanidae. Ichthyol Explor Freshwaters. 2014;24(3):193-207.

200. Arratia G, Quezada-Romegialli C. Understanding morphological variability in a taxonomic context in Chilean diplomystids (Teleostei: Siluriformes), including the description of a new species. PeerJ. 2017;5:e2991.

201. Li J, Xia R, McDowall RM, Lopez JA, Lei G, Fu C. Phylogenetic position of the enigmatic Lepidogalaxias salamandroides with comment on the orders of lower euteleostean fishes. Mol Phylogenet Evol. 2010;57(2):932-6.

202. Rosen DE. Phylogeny and zoogeography of salmoniform fishes and relationships of Lepidogalaxias salamandroides. Bull Am Mus Nat Hist. 1974;153:265-326.

203. Burridge CP, McDowall RM, Craw D, Wilson MVH, Waters JM. Marine dispersal as a pre-requisite for Gondwanan vicariance among elements of the galaxiid fish fauna. J Biogeogr. 2012;39(2):306-21.

204. Wilson MVH, Williams RG. Salmoniform fishes: key fossils, supertree, and possible morphological synapomorphies. In: Nelson JS, Schultze HP, MVH W, editors. Origin and Phylogenetic Interrelationships of Teleosts. München: Verlag Dr. F. Pfeil; 2010. p. 379-402.

205. Sanford CJ. The phylogenetic relationships of salmonoid fishes. Bull Brit Mus Natur Hist, Zool. 1990;56:145-53.

206. Sanford CJ. Salmonid Fish Osteology and Phylogeny (Teleostei: Salmonoidei). Ruggell: Lichtenstein; 2000.

207. Fink WL, Weitzman SH. Relationships of the stomiiform fishes (Teleostei), with a redescription of Diplophos. Bull Mus Comp Zool. 1982;150:31-93
208. Harold AS, Weitzman SH. Interrelationships of stomiiform fishes. In: ML S, Parenti LR, Johnson GD, editors. Interrelationships of fishes. San Diego: Academic Press; 1996. p. 333-53.

209. Harold AS. Phylogenetic relationships of the Gonostomatidae (Teleostei: Stomiiformes). Bull Mar Sci. 1998;62(3):715-41.

210. Johnson GD. Monophyly of the euteleostean clades Neoteleostei, Eurypterygii and Ctenosquamata. Copeia. 1992;8:8-25.

211. Olney JE, Johnson DG, Baldwin CC. Phylogeny of lampridiform fishes. Bull Mar Sci. 1993;52(1):137-69.

212. MLJ S. Basal ctenosquamate relationships and the interrelationships of the myctophiform (scopelomorph) fishes. In: ML S, Parenti LR, Johnson GD, editors. Interrelationships of fishes. San Diego: Academic Press; 1996. p. 405-26

213. Springer VG, Johnson DG. Study of the dorsal gill-arch musculature of teleostome fishes, with special reference to the Actinopterygii. Bulletin of the Biological Society of Washington. 2004;11:1-235.

214. Baldwin C, Johnson GD. Relationships of lower euteleostean fishes. In: ML S, Parenti LR, Johnson GD, editors. Interrelationships of fishes. San Diego: Academic Press; 1996. p. 355-404.

215. Satoh TP, Nakabo T. Paraulopidae and Paraulopus, a new family and genus of aulopiform fshes with revised relationships within the order. Ichthyol Res. 2002;49(1):25-46.

216. Davis MP. Evolutionary relationships of the Aulopiformes (Euteleostei: Cyclosquamata): a molecular and total evidence approach. In: Nelson JS, Schultze HP, MVH W, editors. Origin and Phylogenetic Interrelationships of Teleosts. München: Verlag Dr. F. Pfeil; 2010. p. 317-36.

217. Ghedotti MJ, Barton RW, Simons AM, Davis MP. The first report of luminescent liver tissue in fishes: evolution and structure of bioluminescent organs in the deep-sea naked barracudinas (Aulopiformes: Lestidiidae). J Morphol. 2015;276(3):310-8.

218. Stiassny MLJ. The limits and relationships of the acanthomorph teleosts. J Zool. 1986:411-60.

219. Davesne D, Friedman M, Barriel V, Lecointre G, Janvier P, Gallut C, Otero O: Early fossils illuminate character evolution and interrelationships of Lampridiformes (Teleostei, Acanthomorpha). Zool J Linnean Soc 2014:n/a-n/a.

220. Grande T, Borden WC, Smith WL. Limits and relationships of Paracanthopterygii: a molecular framework for evaluating past morphological hypotheses. In: Arratia G, Schultze H-P, MVH W, editors. Mesozoic Fishes 5 - Global Diversity and Evolution. Verlag Dr. F. Pfeil: Muenchen; 2013.

221. Tyler JC, O'Toole B, Winterbottom R. Phylogeny of the genera and families of zeiform fishes, with comments on their relationships with tetraodontiforms and caproids. Smithsonian Contributions to Zoology. 2003;618:1-51.

222. Endo H. Phylogeny of the order gadiformes (Teleostei, Paracanthopterygii). Mem Grad Sch Fish Sci Hokkaido Univ. 2002;49:75-149.

223. Roa-Varon A, Orti G. Phylogenetic relationships among families of Gadiformes (Teleostei, Paracanthopterygii) based on nuclear and mitochondrial data. Mol Phylogenet Evol. 2009;52(3):688-704.

224. Baldwin C, Johnson GD. A larva of the Atlantic flashlight fish, Kryptophanaron alfredi (Beryciformes: Anomalopidae), with a comparison of beryciform and stephanoberyciform larvae. Bull Mar Sci. 1995;56(1):1-24.

225. Dornburg A, Moore JA, Webster R, Warren DL, Brandley MC, Iglesias TL, et al. Molecular phylogenetics of squirrelfishes and soldierfishes (Teleostei: Beryciformes: Holocentridae): Reconciling more than 100 years of taxonomic confusion. Mol Phylogenet Evol. 2012;65(2):727-38.

226. Dornburg A, Townsend JP, Brooks W, Spriggs E, Eytan RI, Moore JA, et al. New insights on the sister lineage of percomorph fishes with an anchored hybrid enrichment dataset. Mol Phylogenet Evol. 2017;110:27-38.

227. Carnevale G, Johnson D. A Cretaceous Cusk-Eel (Teleostei, Ophidiiformes) from Italy and the Mesozoic Diversification of Percomorph Fishes. Copeia. 2015;103(2015:4):771-91.

228. Howes GJ. Notes on the anatomy and classifi cation of ophidiiform fishes with particular reference to the abyssal genus Acanthonus Günther. Bull Brit Mus (Natur Hist), Zool. 1992;58:95-131.

229. Nielsen JG, Cohen DM, Markle DF, Robins CR. Ophidiiform fishes of the world (Order Ophidiiformes). An annotated and illustrated catalogue of pearlfishes, cusk-eels, brotulas and other ophidiiform fishes known to date, vol. 125; 1999.

230. Patterson C, Rosen D. The Paracanthopterygii revisited: order and disorder. In: Cohen DM, editor. Papers on the systematics of gadiform fishes, vol. 32. Los Angeles: Natural History Museum of Los Angeles County; 1989. p. 5-36.

231. Møller PR, Knudsen SW, Schwarzhans W Nielsen JG. A new classification of viviparous brotulas (Bythitidae) - with the establishment of a new family 
Dinematichthyidae - based on molecular, morphological and fossil data. Mol Phylogenet Evol. 2016;100:391-408.

232. Campbell MA, Nielsen JG, Sado T, Shinzato C, Kanda M, Satoh TP, et al. Evolutionary affinities of the unfathomable Parabrotulidae: Molecular data indicate placement of Parabrotula within the Ophidifformes. Mol Phylogenet Evol. 2017;

233. Greenfield DW, Winterbottom R, Collette BB. Review of the toadfi sh genera (Teleostei: Batra-choididae). Proc California Acad Sci. 2008;59: 665-710.

234. Miya M, Friedman M, Satoh TP, Takeshima H, Sado T, Iwasaki W, et al. Evolutionary origin of the Scombridae (tunas and mackerels): members of a paleogene adaptive radiation with 14 other pelagic fish families. PLoS One. 2013;8(9):e73535.

235. Johnson GD. Scombroid phylogeny: An alternative hypothesis. Bull Mar Sci. 1986;39:1-41.

236. Collette BB, Potthoff T, Richards WJ, Ueyanagi S, Russo JL, Nishikawa Y. Scombroidei: development and relationships. In: Moser H, Richards W, Cohen D, Fahay M, Kendell Jr A, Richardson S, editors. Ontogeny and Systematics of Fishes. Lawrence: American Society of Ichthyologists and Herpetologists Special Publication; 1984. p. 591-620.

237. Doiuchi R, Sato T, Nakabo T. Phylogenetic relationships of the stromateoid fishes (Perciformes). Ichthyol Res. 2004;51(3):202-12.

238. Song HY, Mabuchi K, Satoh TP, Moore JA, Yamanoue Y, Miya M, et al. Mitogenomic circumscription of a novel percomorph fish clade mainly comprising "Syngnathoidei" (Teleostei). Gene. 2014;542(2):146-55.

239. Gosline WA. A reinterpretation of the teleostean fish order Gobiesociformes. Proc California Acad Sci. 1970;37(19):363-82.

240. Kim B-J. Comparative anatomy and phylogeny of the family Mullidae (Teleostei: Perciformes). Mem Grad Sch Fish Sci Hokkaido Univ. 2002:49(1):1-74.

241. Thacker CE. Phylogeny of Gobioidei and placement within acanthomorpha, with a new classification and investigation of diversification and character evolution. Copeia. 2009;2009(1):93-104.

242. Thacker CE, Satoh TP, Katayama E, Harrington RC, Eytan Rl, Near TJ. Molecular phylogeny of Percomorpha resolves Trichonotus as the sister lineage to Gobioidei (Teleostei: Gobiiformes) and confirms the polyphyly of Trachinoidei. Mol Phylogenet Evol. 2015:93:72-9.

243. Berra TM: Nurseryfsh, Kurtus gulliveri (Perciformes: Kurtidae), from northern Australia: Redescription, distribution, egg mass, and comparison with $K$. indicus from southeast Asia. 2003

244. Baldwin C, Johnson GD. Paxton concilians: A new genus and species of pseudamine apogonid (Teleostei: Percoidei) from western Australia: the sister group of the enigmatic Gymnapogon. Copeia. 1999;1999(4):1050-71.

245. Nelson JS. Some characters of Trichonotidae, with emphasis to those distinguishing it from Creediidae (Perciformes: Trachinioidei). Japanese Journal of Ichthyology. 1986;33:1-6.

246. Smith DG, Johnson GD. A New Species of Pteropsaron (Teleostei: Trichonotidae: Hemerocoetinae) from the Western Pacific, with Notes on Related Species. Copeia. 2007;2007(2):364-77.

247. Winterbottom R. Search for the gobioid sister group (Actinopterygii: Percomorpha). Bull Mar Sci. 1993;52:395-414.

248. Johnson GD, Brothers EB. Schindleria: a paedomorphic goby (Teleostei: Gobioidei). Bull Mar Sci. 1993;52:441-71.

249. Travers RA. A review of the Mastacembeloidei, a suborder of synbranchiform teleost fishes. Part II: Phylogenetic analysis. Bull Brit Mus (Natur Hist), Zool. 1984:47:83-150.

250. Britz R. Ontogeny of the ethmoidal region and hyopalatine arch in Macrognathus pancalus (Teleostei, Mastacembeloidei), with critical remarks on mastacembeloid inter- and intrarelationships. Amer Mus Novitates 3181. 1996;3181:1-18.

251. Britz R, Kottelat M. Descriptive osteology of the family Chaudhuriidae (Teleostei, Synbranchiformes, Mastacembeloidei). Amer Mus Novitates. 2002; 3418:1-62.

252. Britz R, Johnson GD. "Paradox Lost": Skeletal ontogeny of Indostomus paradoxus and its significance for the phylogenetic relationships of Indostomidae (Teleostei, Gasterosteiformes). Amer Mus Novitates. 2002;3383:1-43.

253. Rosen DE, Greewood PH. A fourth Neotropical species of synbranchid eel and the phylogeny and systematics of synbranchiform fishes. Bull Amer Mus Natur Hist. 1976;157:1-70.

254. Britz R. Ontogenetic features of Luciocephalus (Perciformes, Anabantoidei), with a revised hypothesis of anabantoid intrarelationships. Zool J Linnean Soc. 1994;112:491-508
255. Britz R. Suborder Anabantoidei: Labyrinth fishes. In: Hutchins M, Thoney DA, Loiselle PV, Schlager N, editors. Grzimek's Animal Life Encyclopedia, vol. 5. Fishes II, 2nd ed. Farmington Hills: Gale Group; 2003. p. 427-36.

256. Collins RA, Britz R, Rüber L. Phylogenetic systematics of leaffishes (Teleostei: Polycentridae, Nandidae). J Zool Syst Evol Res. 2015;53(4):259-72.

257. Little AG, Lougheed SC, Moyes CD. Evolutionary affinity of billfishes (Xiphiidae and Istiophoridae) and flatfishes (Plueronectiformes): independent and trans-subordinal origins of endothermy in teleost fishes. Mol Phylogenet Evol. 2010;56(3):897-904.

258. Friedman M. Osteology of tHeteronectes chaneti (Acanthomorpha, Pleuronectiformes), an Eocene stem flatfish, with a discussion of flatfish sister-group relationships. J Vertebr Paleontol. 2012;32(4):735-56.

259. Betancur-R R, Li C, Munroe TA, Ballesteros JA, Orti G. Addressing gene-tree discordance and non-stationarity to resolve a multi-locus phylogeny of the flatfishes (Teleostei: Pleuronectiformes). Syst Biol. 2013;62(5):763-85

260. Betancur-R R, Orti G. Molecular evidence for the monophyly of flatfishes (Carangimorpharia: Pleuronectiformes). Mol Phylogenet Evol. 2014; 73(2014):18-22.

261. Campbell MA, Chen WJ, Lopez JA. Are flatfishes (Pleuronectiformes) monophyletic? Mol Phylogenet Evol. 2013;69(3):664-73.

262. Greenwood PH. A review of the family Centropomidae (Pisces, Perciformes). Bulletin of the British Museum (Natural History) Zoology. 1976;29:1-81

263. Nakamura I. Systematics of the billfishes (Xiphiidae and Istiophoridae). Publ Seto Mar Biol Lab. 1983;28(5-6):255-396.

264. Smith-Vaniz WF. Carangidae: relationships. In: Moser HG, Richards WJ, Cohen DM, Fahay MP, Kendell Jr AW, Richardson SL, editors. Ontogeny and Systematics of Fishes, vol. 1: Am. Soc. Ichthyo. Herpe. Spec. Publ; 1984. p. 640-70.

265. Chapleau F. Pleuronectiform relationships - A cladistic reassessment. Bull Mar Sci. 1993:52(1):516-40.

266. Munroe TA. Chapter 2: Systematic Diversity of the Pleuronectiformes. In: Gibson RN, editor. Flatfishes: Biology and Exploitation. Oxford: Blackwell Science Ltd; 2005. p. 10-41.

267. Wainwright PC, Smith WL, Price SA, Tang KL, Sparks JS, Ferry LA, et al. The evolution of pharyngognathy: a phylogenetic and functional appraisal of the pharyngeal jaw key innovation in labroid fishes and beyond. Syst Biol. 2012;61(6):1001-27.

268. Godkin CM, Winterbottom R. Phylogeny of the family Congrodgadidae (Pisces: Perciformes) and its placement as a subfamily of Pseudochromidae. Bull Mar Sci. 1985;36(3):633-71.

269. Gill A, Mooi RD. Monophyly of the Grammatidae and of the Notograptidae, with evidence for their phylogenetic positions among perciforms. Bull Mar Sci. 1993;52(1):327-50.

270. Parenti LR. Relationships of atherinomorph fishes (Teleostei). Bull Mar Sci. 1993;52:170-96.

271. Springer VG, Orrell TM. Phylogenetic analysis of the families of acanthomorph fishes based on dorsal gill-arch muscles and skeleton. Bulletin of the Biological Society of Washington. 2004;11:237-60.

272. Parenti LR. The Phylogeny of Atherinomorphs: Evolution of a Novel Fish Reproductive System. In: Uribe MC, Grier HJ, editors. Viviparous Fishes Systematics, Biogeography, and Evolution. Homestead: New Life Publications; 2005. p. 13-30.

273. Dyer BS, Chernoff B. Phylogenetic relationships among atheriniform fishes Zool J Linnean Soc. 1996;117:1-69.

274. Campanella D, Hughes LC, Unmack PJ, Bloom DD, Piller KR, Orti G. Multilocus fossil-calibrated phylogeny of Atheriniformes (Teleostei, Ovalentaria). Mol Phylogenet Evol. 2015;86:8-23.

275. Rosen DE, Parenti LR. Relationships of Oryzias and the groups of atherinomorph fishes. Amer Mus Novitates. 1981;2719:1-15.

276. Parenti LR. A phylogenetic analysis and taxonomic revision of ricefishes, Oryzias and relatives (Beloniformes, Adrianichthyidae). Zool J Linnean Soc. 2008;154:494-610

277. Parenti LR. A phylogenetic and biogeographic analysis of cyprinodontiform fishes (Teleostei, Atherinomorpha). Bull Am Mus Nat Hist. 1981;168.

278. Lovejoy NR, Collette BB. Phylogenetic relationships of new world needlefishes (Teleostei : Belonidae) and the biogeography of transitions between marine and freshwater habitats. Copeia. 2001; 2:324-38.

279. Lovejoy NR, Iranpour M, Collette BB. Phylogeny and jaw ontogeny of beloniform fishes. Integr Comp Biol. 2004;44(5):366-77. 
280. Costa WJEM. Phylogeny and classification of Rivulidae revisited: origin and evolution of annualism and miniatureization in rivulid fishes (Cyprinodontiformes: Aplocheiloidei). J Comp Biol. 1998;3(1):33-94.

281. Costa WJEM. Phylogeny and classification of the Cyprinodontidae revisited (Teleostei: Cyprinodontiformes): are Andean and Anatolian killifishes sister taxa? J Comp Biol. 1997;2(1):1-17.

282. Pollux BJ, Meredith RW, Springer MS, Garland T, Reznick DN. The evolution of the placenta drives a shift in sexual selection in livebearing fish. Nature. 2014;513(7517):233-6.

283. Pohl M, Milvertz FC, Meyer A, Vences M. Multigene phylogeny of cyprinodontiform fishes suggests continental radiations and a rogue taxon position of Pantanodon. Vertebrate Zoology. 2015;65(1):37-44.

284. Stiassny MLJ. What are grey mullets? Bull Mar Sci. 1993;52:197-219.

285. Lin $\mathrm{H}-\mathrm{C}$, Hastings PA. Phylogeny and biogeography of a shallow water fish clade (Teleostei: Blenniiformes). BMC Evol Biol. 2013:13

286. Parenti LR, Song J. Phylogenetic Significance of the pectoral-pelvic fin association in acanthomorph fishes: a reassessment using comparative neuroanatomy. In: MLJ S, Parenti LR, Johnson GD, editors. Interrelationships of Fishes. San Diego: Academic Press; 1996. p. 427-44.

287. Springer V. Definition of the suborder Blennioidei and its included families (Pisces: Perciformes). Bull Mar Sci. 1993;52:472-95.

288. Mooi RD, Gill AC. Association of epaxial musculature with dorsal-fin pterygiophores in acanthomorph fishes, and its phylogenetic significance. Bull Natur Hist Mus London (Zool). 1995;61(2):121-37.

289. Smith WL, Wheeler WC. Venom evolution widespread in fishes: a phylogenetic road map for the bioprospecting of piscine venoms. J Hered 2006;97(3):206-17.

290. Imamura H, Odani K. An overview of the phylogenetic relationships of the suborder Trachinoidei (Acanthomorpha: Perciformes). Ichthyol Res. 2013. 2013(60):1-15.

291. Stiassny M, Jensen J. Labroid intrarelationships revisited: morphological complexity, key innovations, and the study of comparative diversity. Bulletin of the Museum of Comparative Zoology. 1987;151:269-319.

292. Holcroft NI, Wiley EO. Acanthuroid relationships revisited: a new nuclear gene-based analysis that incorporates tetraodontiform representatives. Ichthyol Res. 2008;55:274-83.

293. Tyler JC, Johnson GD, Nakamura I, Collette BB. Morphology of Luvarus imperialis (Luvaridae), with a phylogenetic analysis of the Acanthuroidei. Smithsonian Contributions to Zoology. 1989;485:1-78.

294. Miller TL, Cribb TH. Phylogenetic relationships of some common IndoPacific snappers (Perciformes: Lutjanidae) based on mitochondrial DNA sequences, with comments on the taxonomic position of the Caesioninae. Mol Phylogenet Evol. 2007:44(1):450-60.

295. Leis JM, Carson-Ewart BM. The larvae of Indo-Pacific coastal fishes. An identification guide to marine fish larvae. Fauna Malesiana Handbooks 2 Brill; 2000.

296. Akazaki M. Studies on the spariform fishes-anatomy - phylogeny, ecology, and taxonomy. Osaka: Kosugi Co. Ltd.; 1962.

297. Johnson GD. The limits and relationships of the Lutjanidae and associated families. Bulletin of the Scripps Institution of Oceanography. 1981;24:1-114

298. Santini F, Carnevale G, Sorenson L. First multi-locus timetree of seabreams and porgies (Percomorpha: Sparidae). Italian Journal of Zoology 2014;81(1):55-71.

299. Santini F, Lecointre G. Phylogeny of the Caproidae (Acanthomorpha) with comments on their relationship with Tetraodontiformes and Acanthuroidae. In: Integrative and Comparative Biology: 2005: Oxford University Press. p. 1189-9.

300. Pietsch TW. The osteology and relationships of the anglerfish genus Tetrabrachium, with comments on lophiiform classification. US Fish Bull. 1981;79:387-419.

301. Pietsch TW. Lophiiformes: Development and relationships. In: Moser HG, Richards WJ, Cohen DM, Fahay MP, Kendell Jr AW, Richardson SL, editors. Ontogeny and Systematics of Fishes, vol. 1. Lawrence: American Society of Ichthyologists and Herpetologists Special Publication; 1984. p. 320-5.

302. Chanet B, Guintard C, Betti E, Gallut C, Dettai A, Lecointre G. Evidence for a close phylogenetic relationship between the teleost orders Tetraodontiformes and Lophiiformes based on an analysis of soft anatomy. Cybium. 2013;37(3):179-98.

303. Baldwin CC. The phylogenetic significance of colour patterns in marine teleost larvae. Zool J Linnean Soc. 2013;168(3):496-563.
304. Miya M, Pietsch T, Orr J, Arnold R, Satoh T, Shedlock A, et al. Evolutionary history of anglerfishes (Teleostei: Lophiiformes): a mitogenomic perspective. BMC Evol Biol. 2010;10(1):58.

305. Pietsch TW, Grobecker DB. Frogfishes of the world. Systematics, Zoogeography \& Behavioral ecology. Stanford: Stanford University Press; 1987.

306. Pietsch T, Orr J. Phylogenetic relationships of deep-sea anglerfishes of the suborder Ceratioidei (Teleostei: Lophiiformes) based on morphology. Copeia. 2007;2007:1-34.

307. Tyler JC: Osteology phylogeny and higher classification of the fishes of the order plectognathi tetraodontiformes. vol. 431: NMFS Circ; 1980.

308. Tyler JC, Santini F. Review and reconstruction of the tetraodontiforms fishes from the eocene of Monte Bolca, Italy, with comments on related tertiary taxa. Studi e Ricerche sui Glacimenti Terziari di Bolca, Museo Civico di Storia Naturale di Verona. 2002;9:47-119.

309. Tyler JC, Sorbini L. New superfamily and three new families of tetraodontiform fishes from the Upper Cretaceous: the earliest and most morphologically primitive plectognaths. Smithson Contrib Paleobiol. 1996:82:1-59.

310. Santini F, Tyler JC. A phylogeny of the families of fossil and extant tetraodontiform fishes (Acanthomorpha, Tetraodontiformes), Upper Cretaceous to recent. Zool J Linnean Soc. 2003;139:565-617.

311. Bannikov AF, Tyler JC, Arcila D, Carnevale G. A new family of gymnodont fish (Tetraodontiformes) from the earliest Eocene of the Peri-Tethys (Kabardino-Balkaria, northern Caucasus, Russia). J Syst Palaeontol. 2016:1-18

312. Tominaga $Y$. The relationships of the families Glaucosomatidae and Pempherididae. In: Uyeno T, Arai R, Taniuchi T, Matsuura K, editors. IndoPacific fish biology. Tokyo: Ichthyological Society of Japan; 1986. p. 595-9.

313. Near TJ, Dornburg A, Harrington RC, Oliveira C, Pietsch TW, Thacker CE, et al Identification of the notothenioid sister lineage illuminates the biogeographic history of an Antarctic adaptive radiation. BMC Evol Biol. 2015;15:109.

314. Odani K, Imamura H. New Phylogenetic Proposal for the Family Leptoscopidae (Perciformes: Trachinoidei). Bulletin of Fisheries Sciences Hokkaido University. 2011;61(2):49-63.

315. Chen W-J, Lavoué S, Beheregaray LB, Mayden RL, Riddle B. Historical biogeography of a new antitropical clade of temperate freshwater fishes. J Biogeogr. 2014;41(9):1806-18

316. Lavoué S, Nakayama K, Jerry DR, Yamanoue Y, Yagishita N, Suzuki N, et al. Mitogenomic phylogeny of the Percichthyidae and Centrarchiformes (Percomorphaceae): comparison with recent nuclear gene-based studies and simultaneous analysis. Gene. 2014;549(1):46-57.

317. Li C, Orti G, Zhao J. The phylogenetic placement of sinipercid fishes ("Perciformes") revealed by 11 nuclear loci. Mol Phylogenet Evol. 2010;56(3):1096-104.

318. Near TJ, Sandel M, Kuhn KL, Unmack PJ, Wainwright PC, Leo Smith W. Nuclear gene-inferred phylogenies resolve the relationships of the enigmatic Pygmy Sunfishes, Elassoma (Teleostei: Percomorpha). Mol Phylogenet Evol. 2012;63(2):388-95

319. Greenwood PH. A revised familial classification for certain cirrhitoid genera (Teleostei, Percoidei, Cirrhitoidea), with comments on the groups monophyly and taxonomic ranking. Bulletin of the British Museum (Natural History) Zoology. 1995;61:1-10.

320. Burridge CP, Smolenski AJ. Molecular phylogeny of the Cheilodactylidae and Latridae (Perciformes: Cirrhitoidea) with notes on taxonomy and biogeography. Mol Phylogenet Evol. 2004:30(1):118-27.

321. Yagishita N, Miya M, Yamanoue Y, Shirai SM, Nakayama K, Suzuki N, et al. Mitogenomic evaluation of the unique facial nerve pattern as a phylogenetic marker within the percifom fishes (Teleostei: Percomorpha). Mol Phylogenet Evol. 2009;53(1):258-66.

322. Johnson GD, Fritzsche RA. Graus nigra Philippi, an omnivorous girellid, with comments on relationships of the Girellidae (Pisces: Perciformes). Proc Acad Natur Sci Philadelphia. 1989;141:1-27.

323. Carpenter K. Girellidae, Scorpididae, Microcanthidae. In: Carpenter K, Niem VH, editors. The Living Marine Resources of the Western Central Pacific FAO Species Identification Guide for Fisheries Purposes, vol. 5. Rome: FAO; 2001. p. 2791-3379.

324. Yagishita N, Kobayashi T, Nakabo T. Review of monophyly of the Kyphosidae (sensu Nelson, 1994), inferred from the mitochondrial ND2 gene. Ichthyol Res. 2002;49:103-8.

325. Knudsen SW. Revision of the fish family Kyphosidae (Teleostei: Perciformes). Zootaxa. 2013;3751:1-101.

326. Knudsen SW, Clements KD. World-wide species distributions in the family Kyphosidae (Teleostei: Perciformes). Mol Phylogenet Evol. 2016;101:252-66. 
327. Davis A, Unmack P, Vari RP, Betancur-R R. Herbivory promotes dental disparification and macroevolutionary dynamics in grunters (Teleostei: Terapontidae), a freshwater adaptive radiation. Am Nat. 2016;187(3):320-33.

328. Lautredou A-C, Motomura H, Gallut C, Ozouf-Costaz C, Cruaud C, Lecointre $\mathrm{G}$, et al. Multi-scale exploration of the relationships among Serraniformes (Acanthomorpha, Teleostei) using new nuclear markers. Mol Phylogenet Evol. 2013;67(1):140-55.

329. Yabe M, Uyeno T. Anatomical description of Normanichthys crockeri (Scorpaeniformes, incertae sedis: family Normanichthyidae). Bull Mar Sci. 1996;58:494-510

330. Johnson GD: Niphon spinosus: A primitive epinepheline serranid, with comments on the monophyly and intrarelationships of the Serranidae. Copeia. 1983(3):777-87.

331. Baldwin C, Johnson GD. Phylogeny of the Epinephelinae (Teleostei: Serranidae). Bull Mar Sci. 1993;52:240-80.

332. Ma KY, Craig MT, Choat JH, van Herwerden L. The historical biogeography of groupers: clade diversification patterns and processes. Mol Phylogenet Evol. 2016;100:21-30

333. Craig MT, Hastings PA. A molecular phylogeny of the groupers of the subfamily Epinephelinae (Serranidae) with a revised classification of the Epinephelini. Ichthyol Res. 2007;54:1-17.

334. Hastings PA. Relationships of fishes of the perciform suborder Notothenioidei. In: Miller RC, editor. History and Atlas of the Fishes of the Antarctic Ocean. Carson: Forresta Institute for Ocean and Mountain Studies; 1993. p. 99-107.

335. Derome N, Chen WJ, Dettai A, Bonillo C, Lecointre G. Phylogeny of Antarctic dragonfishes (Bathydraconidae, Notothenioidei, Teleostei) and related families based on their anatomy and two mitochondrial genes. Mol Phylogenet Evol. 2002;24(1):139-52.

336. Imamura H. Phylogenetic relationships and new classification of the superfamily Scorpaenoidea (Actinopterygii: Perciformes). Species Diversity. 2004;9:1-36.

337. Imamura I, Yabe M. Demise of the Scorpaeniformes (Actinopterygii: Percomorpha): an alternative phylogenetic hypothesis. Bull Fish Sci Hokkaido Univ. 2002;53:107-28

338. Mandrytsa SA. Seismosensory system and classification of scorpionfishes (Scorpaeniformes: Scorpaenodei). Perm: Perm State University Press; 2001.

339. Honma Y, Imamura H, Kawai T. Anatomical description of the genus Perryena and proposal to erect a new family for it based on its phylogenetic relationships with related taxa (Scorpaeniformes). Ichthyol Res. 2013;60(2):122-41.

340. Imamura H. Phylogeny of the Family Platycephalidae and Related Taxa (Pisces: Scorpaeniformes). Species Diversity. 1996;1:123-233.

341. Jordan DS. A classification of fishes including families and genera as far as known. Stanford Univ Publ, Univ Ser Biol Sci. 1923;3(2):77-243.

342. Imamura H, Shirai S, Yabe M. Phylogenetic position of the family Trichodontidae (Teleostei: Perciformes), with a revised classification of the perciform suborder Cottoidei. Ichthyol Res. 2005;52:264-74.

343. Anderson ME. Systematics and osteology of the Zoarcidae (Teleostei: Perciformes). Ichthyol Bull J L B Smith Inst Ichthyol. 1994;60:1-120.

344. Kwun HJ, Kim JK. Molecular phylogeny and new classification of the genera Eulophias and Zoarchias (Pisces, Zoarcoidei). Mol Phylogenet Evol. 2013; 69(3):787-95.

345. Smith WL, Busby MS. Phylogeny and taxonomy of sculpins, sandfishes, and snailfishes (Perciformes: Cottoidei) with comments on the phylogenetic significance of their early-life-history specializations. Mol Phylogenet Evol. 2014;79:332-52

346. Washington BB, Eschmeyer WN, Howe KM. Scorpaeniformes: relationships. In: Moser H, Richards W, Cohen D, Fahay M, Kendell Jr A, Richardson S, editors. Ontogeny and Systematics of Fishes. Lawrence: American Society of Ichthyologists and Herpetologists Special Publication; 1984. p. 438-47.

347. Shinohara G. Memoirs of the Faculty of Fisheries Hokkaido University. 1994;4:1-97.

348. Cloutier R, Ahlberg P. Morphology, Characters, and the Interrelationships of Basal Sarcopterygians. In: MLJ S, Parenti LR, Johnson GD, editors. Interrelationships of fishes. San Diego: Academic Press; 1996. p. 445-80.

349. Schultze HP, Cloutier R. Comparison of the Escuminac Formation ichthyofaunal with other late Givetian/early Frasnian ichthyofaunas. In: Schultze HP, Cloutier R, editors. Devonian Fishes and Plants of Miguasha, Quebec, Canada. Munich: Verlag Dr. Friedrich Pfeil; 1996. p. 348-68.

350. Dutel H, Maisey JG, Schwimmer DR, Janvier P, Herbin M, Clément G. The giant Cretaceous coelacanth (Actinistia, Sarcopterygii) Megalocoelacanthus dobiei Schwimmer, Stewart \& Williams, 1994, and its bearing on Latimerioidei interrelationships. PLoS One. 2012;7(11):e49911.
351. Arratia G, Schultze HP. A new fossil actinistian from the Early Jurassic of Chile and its bearing on the phylogeny of Actinistia. J Vertebr Paleontol. 2015;e983524:983512.

352. Chen MY, Liang D, Zhang P. Selecting question-specific genes to reduce incongruence in phylogenomics: a case study of jawed vertebrate backbone phylogeny. Syst Biol. 2015;64(6):1104-20.

353. Irisarri I, Meyer A. The identification of the closest living relative(s) of tetrapods: phylogenomic lessons for resolving short ancient internodes. Syst Biol. 2016.

354. Schultze HP, Campbell KSW. Characterization of the Dipnoi, a monophyletic group. J Morphol. 1987;(Suppl. 1):25-37.

355. Bemis WE. Feeding systems of living Dipnoi; anatomy and function. J Morphol. 1986;190(Supplement S1):249-75.

356. Arratia G, Schultze HP, Casciotta J. Vertebral column and associated elements in dipnoans and comparison with other fishes: Development and homology. J Morphol. 2001;250(2):101-72.

357. Imamura $\mathrm{H}$, Yabe M. Larval record of a red firefish, Pterois volitans, from northwestern Australia (Pisces: Scorpaeniformes). Bulletin of the Faculty of Fisheries Hokkaido University. 1996;47(2-3):41-6.

\section{Submit your next manuscript to BioMed Central and we will help you at every step:}

- We accept pre-submission inquiries

- Our selector tool helps you to find the most relevant journal

- We provide round the clock customer support

- Convenient online submission

- Thorough peer review

- Inclusion in PubMed and all major indexing services

- Maximum visibility for your research

Submit your manuscript at www.biomedcentral.com/submit
) Biomed Central 